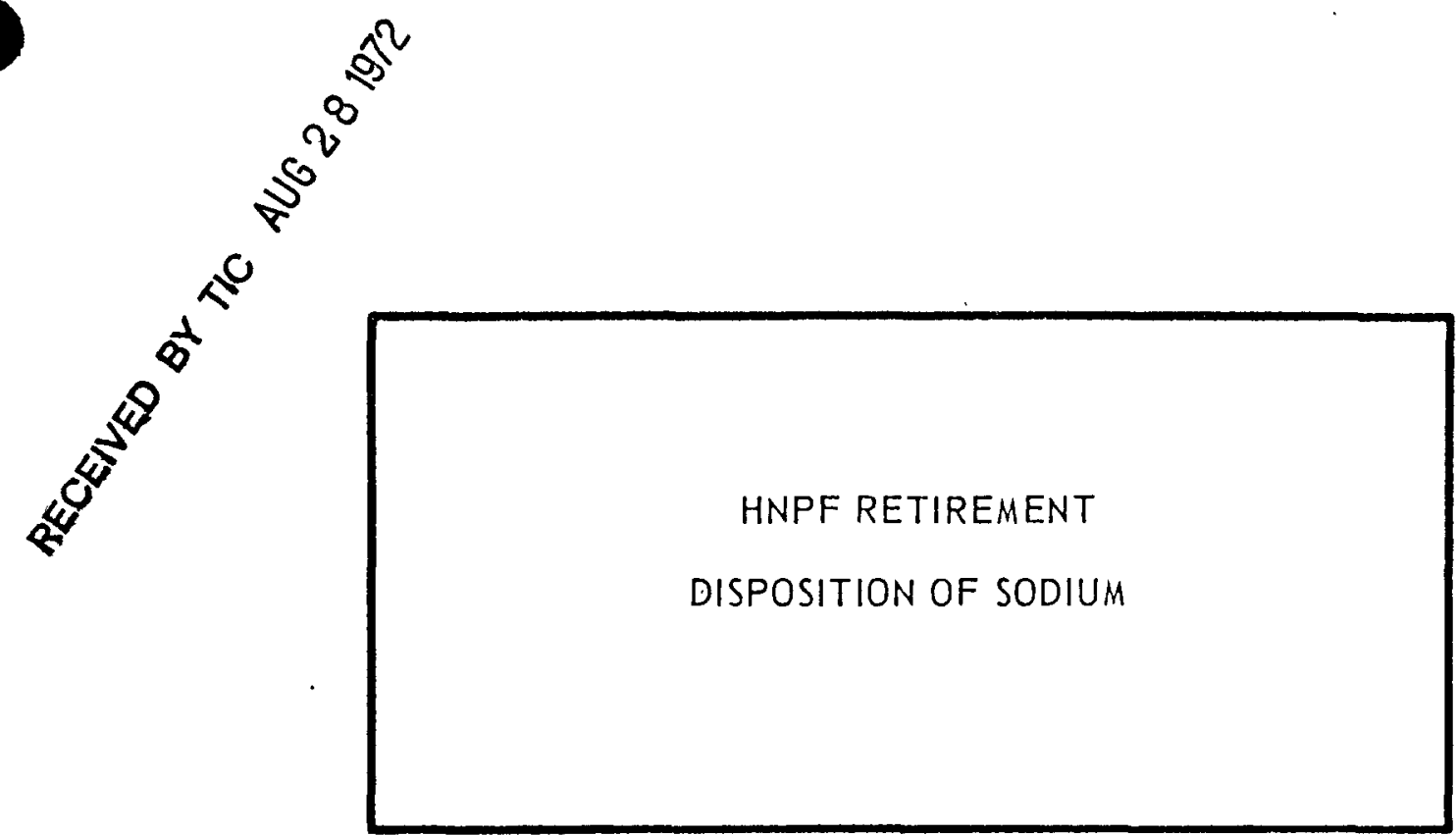

By

T. J. BOARDMAN

T. A. PAULETT

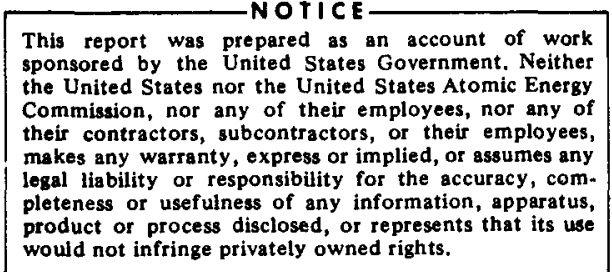

would not infringe privately owned rights.

\title{
ATOMICS INTERNATIONAI,
}

A DIVISION OF NORTHAMERICAN ROCKWELL CORPORATION 


\section{DISCLAIMER}

This report was prepared as an account of work sponsored by an agency of the United States Government. Neither the United States Government nor any agency Thereof, nor any of their employees, makes any warranty, express or implied, or assumes any legal liability or responsibility for the accuracy, completeness, or usefulness of any information, apparatus, product, or process disclosed, or represents that its use would not infringe privately owned rights. Reference herein to any specific commercial product, process, or service by trade name, trademark, manufacturer, or otherwise does not necessarily constitute or imply its endorsement, recommendation, or favoring by the United States Government or any agency thereof. The views and opinions of authors expressed herein do not necessarily state or reflect those of the United States Government or any agency thereof. 


\section{DISCLAIMER}

Portions of this document may be illegible in electronic image products. Images are produced from the best available original document. 


\section{ACKNOWLEDGMENT}

The author wishes to acknowledge the contributions of the members of Consumers Public Power District for their cooperation in planning and performing the work during this phase of the retirement program and for the gathering and submittal of data and other pertinent information in this report. 


\section{CONTENTS}

Page

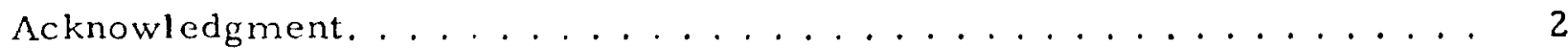

I. Introduction. ................... 7

II. Draining the Reactor Vessel. . . . . . . . . . . . 9

III. Removal and Shipment of Bulk Sodium .............. 13

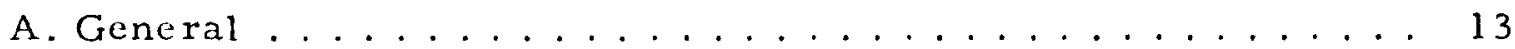

B. Removal of Tanks from Underground Vaults .......... 15

C. Loading of Tanks on Railroad Cars .............. 17

D. Shipping of Tanks ................... 18

IV. Disposal of Secondary Main Sodium Piping . . . . . . . . . . 23

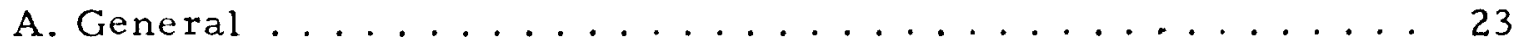

B. Removal of Secondary Sodium Piping. . . . . . . . . . . 23

C. Cleaning of Secondary Sodium Piping . . . . . . . . . 25

V. Reaction of Residual Sodium in Primary Heat Transfer

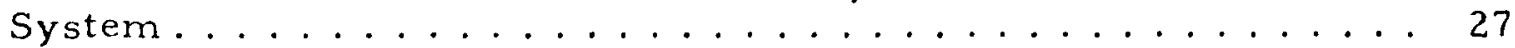

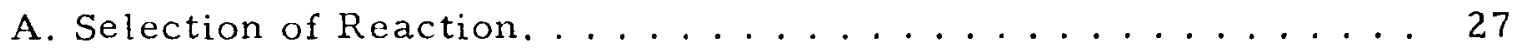

B. Preparation of Heat Transfer System. . . . . . . . . . 31

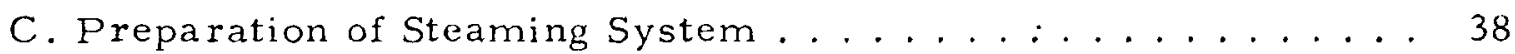

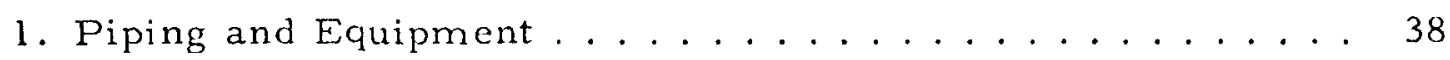

2. Instrumentation .................. 50

D. Preparation of Existing Facilities............. 54

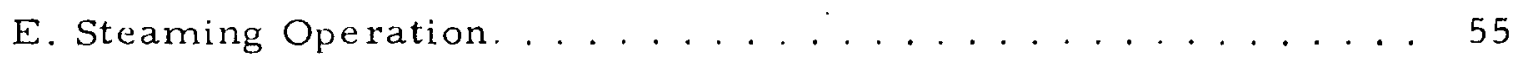

1. Steaming Reactor Vessel................ 55

2. Steaming Heat Transfer Loops .............. 58

F. Analysis of Results from Reactor Steaming Operation. . . . . 6 60

1. Calculated Results ... . . . . . . . . . . . . . 60

2. Inspection Results .................... 64

3. Potential Effects of Residue................ 69

VI. Disposal of Sodium Service Piping. ............. 71

A. Removal of Secondary Sodium Service Piping .......... 71

B. Cleaning of Secondary Sodium Service Piping . . . . . . . . 71

C. Removal of Primary Sodium Service Piping . . . . . . . . . 74

D. Cleaning of Primary Sodium Service Piping . . . . . . . 74

$$
A I-A F C-M F M O-12736
$$




\section{CONTENTS}

Page

VII. Removal and Disposition of Major Components . . . . . . . . 75

A. Main Sodium Block and Throttle Valves . . . . . . . . . . 75

B. Steam Generators and Related Components . . . . . . . . . 77

C. Intermediate Heat Exchangers . . . . . . . . . . . 79

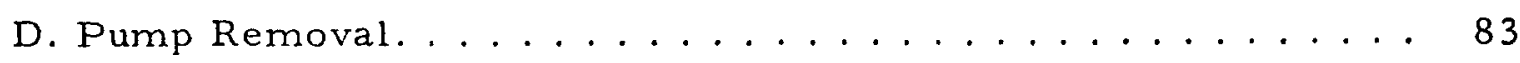

1. Primary Sodium Pumps................ 83

2. Secondary Sodium Pumps. ................ 85

3. Sodium Service EM Pumps. . . . . . . . . . . . . 86

VIII. References ........................ 87

Appendices

A. Specifications and Procedures ................ 89

B. Activity Specification No. 5 - Reaction of Residual

Primary Sodium and Retirement of Primary Sodium

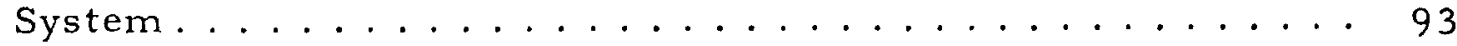

C. Retirement Detailed Procedure 5-5, Reaction of

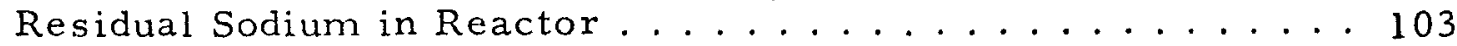

D. Mathematical Analysis of Data ............... 117

1. Derivation of Equations for Analysis of Sodium Steam Reaction ................. 119

2. Analysis of Data for Correlation Between Inlet Orifice Meter Readings (FI-1 and FI-2) and Pressure Drop Between Upstream Orifice Pressure Taps and Mixing Tank ............... 127

3. Listing of FORTRAN IV Computer Program for Calculation of Results from Steaming of Reactor Vessel....................... 129

4. Listing of Input Data for Calculation of Results from Sodium - Steam Reaction . . . . . . . . . . . 133

\section{TABLES}

1. Instrumentation List ................... 51

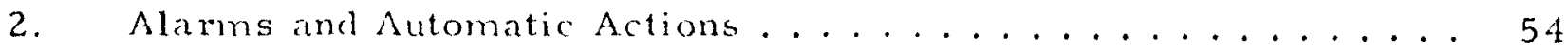

3. HNPF Retirement Results from Stedming of Reactor Vessel . . . 65 


\section{FIGURES}

Page

1. Sketch of Reactor Vessel and Connecting Piping. . . . . . . . 10

2. Routing of Flow for Draining Sudium "Ileel" from Bottom

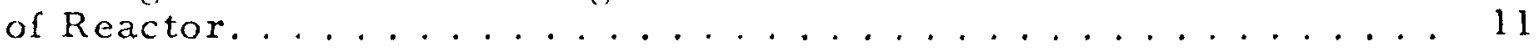

3. Temporary Reactor Drain Line. . . . . . . . . . . . . 12

4. Sketch Showing Location of Primary and Secondary Sodium Storage Tanks ........................ 14

5. Secondary Sodium Storage. Tank Removed from Underground

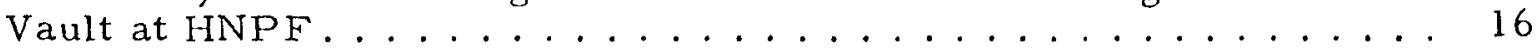

6. Primary Sodium Storage Tank Being Removed from Underground Vault at HNPF ................... 16

7. Secondary Sodium Storage Tank Being Anchored to Railroad Flatcar in Preparation for Shipment ............ 18

8. Typical Tiedown Arrangement and Details Used for Shipping

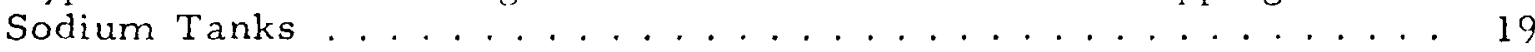

9. Loading of Primary Sodium Tanks Onto Flatcar, and the Ballast Arrangement. . . . . . . . . . . . . . . 20

10 Rail Transport of Primary Sorlium Tanks, and Trackside

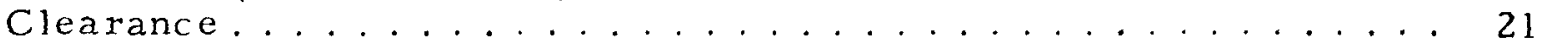

11. Unloading Secondary Sodium Tank at Chatsworth, and Truck

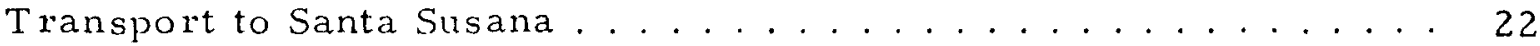

12. Typical Sodium Loop Isolation Diagram . . . . . . . . . . . 24

13. Main Sodium Piping in Scrap Pile After Cleaning . . . . . . . 25

14. Process P\&ID Sodium Heat Transfer System . . . . . . . . . 33

15. Main Sodium Piping in Fast Gallery with Pipe Caps and Stub Ends Welded Into Place................... 35

16. Main Sodium Piping in West Gallery with Pipe Caps and Stub Ends Welded Into Place. . . . . . . . . . . . . . . 35

17. IHX Outlet and Pump Discharge Lines Cut and Capped in Preparation for Installation of liypass Loop ........... 36

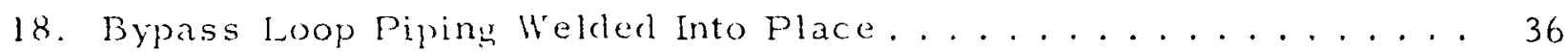

19. liypass Loop piping with lleaters and The rmocouple

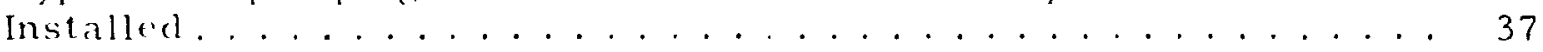

20 Completed Bypass loop Installation. . . . . . . . . . 37

21 IINPF l'd I Diagrum process System Reartuon of Residual Sodimm . . . . . . . . . . . . . . . . . . . 39

22. IINPF l'BI Diagram Process System Reaction of Residual Sodium in promary lipe loops. . . . . . . . . . . . . 


\section{FIGURES}

Page

23. Overall View of Reactor Building Main Floor with Steaming

System Installed....................... 44

24. Manual Throttling Station. ................... 44

25. Hatch $9 \mathrm{~A}$ on East Side of Reactor ................ 46

26. Hatch $9 \mathrm{~B}$ on We st Side of Reactor ................ 46

27. Manifold and Connecting Pipes in West Pipe Gallery. . . . . . . . 47

28. Effluent Condenser and Gas Analyzer Equipment . . . . . . . . . 47

29. Typical Connection to Primary Pump Case During Installation . . . 48

30. Typical Connection to Primary Pump Case After Installation

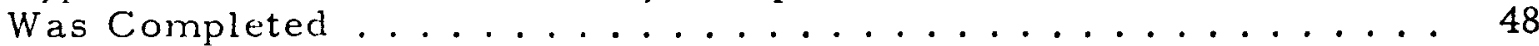

31. Copy of Hydrogen Analyzer Recording Strip Section . . . . . . . 57

32. Sodium Disposal Facility Buildings . . . . . . . . . . . . . 72

33. Interior of Sodium Cleaning Building . . . . . . . . . . 73

34. Primary Sodium Block Valve After Cleaning at Santa Susana . . . 76

35. Primary Sodium Throttle Valve After Arrival at Santa Susana . . . 78

36. HNPF Steam Gene rator As sembly . . . . . . . . . . . . . 78

37. HNPF Intermediate Heat Exchanger. . . . . . . . . . . . 80

38. IHX Module Being Removed from Vault . . . . . . . . . . . 81

39. IHX Module With Shipping Skid Being Lowered to Floor. . . . . . . 82

40. Free-Surface Sodium Pump .................. 84 


\section{INTRODUCTION}

Iwo principal requirements for the retirement $(1) *$ of the Hallam Nuclear power Facility (HNPF) were:

1) "Removal from the site of all sodium that can be drained from the system."

2) "Chemical reaction of residual sodium then remaining in the system, including all process lines, tanks, and the reactor vessel."

This report covers the plans, performance. and results of the operations acomplished in fulfilling these requirements. Since the overall retirement program covered a large scope of work. considerable planning was necessary to ensure that all tasks would be accomplished such that no health or safety hayard would be cncountered cither during or after the operations.

As a part of this planning, Atomics International (AI) prepared activity specifications covering the tasks to be accomplished and the requirements for rach phase of the program. Consumers Public Power District (CPPD) prepared procedures detailing the manner in which each operation was to be performed in carrying out the various tasks. A list of all the activity specification; and operating procedures may be found in Appendix A. This report covers the removal of all bulk sodium from the HNPF site and the chemical reaction of residual sodium at the site.

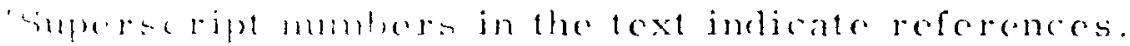

$$
A]-A I:(:-11: N 10-12736
$$


$$
\text { . }
$$ 


\section{DRAINING THE REACTOR VESSEL}

'The reactor vesscl is a cylindrical, stainless-steel, vessel approximately $38 \mathrm{ft}$ in diameter and $40 \mathrm{ft}$ deep with connecting piping as shown in Figure 1 . The top surface or loading face is flush with the main floor of the reactor huitding. The vessel had been previously drained, as far as possible, by pumping the sodium out through the $3-i n$. fill-and-drain line and by using existing plant rquipinent, two linear-induction, electromagnetic pumps.

Due to the drain pipe configuration, the pumping operation left a sodium "hecl" about two inches deep in the bottom of the vessel. In order to reduce the amount of residual sodium to be chemically reacted, it was desirable to remove as mich of this "heel" as possible from the vessel. The 2-in. layer represented about $2400 \mathrm{lb}$ of sodium. The problem was one of lifting the sodium to the top of the vessel, elevation $1440 \mathrm{ft} 6 \mathrm{in}$, and then draining it to a part of the system from which it could be transferred to the storage tanks. In order to accomplish this, a pipe, extending to the reactor bottom, was installed through a fuel plug hole in the loading face shield. This pipe was then used to transport the sodium to the main floor level and to drain it into the sodjum service system. The installation was designed to maintain the inert atmosphere in the reactor.

After a brief investigation of a specially designed lift pump similar to those uscd in wells, it was decided to use a combination of pressure inside the reactor and vacuum on the sodium service system to transfer the fluid. The design strength of the reactor bellows prohibited the use of pressure alone, and the depth of the reactor vessel prevented the use of vacuum alone. The routing of the drain flow was from the reactor vessel through a temporary drain pipe to the containment drain tank, Figure 2. From the containment drain tank, sodium was transferred to the primary sodium drain tank and then to the No. 1 primary sodium storage tank. Since the containment drain tank could not hold (1) the sodium, the operation was performed in steps.

lirst, a trmpopary drain line was installed from the reactor vessel, thenhth a specially modified fucl plug, to the containment drain tank, see Fign. ;. After the lines were preheated, a vacuum was drawn on the contain11611 drain tink, and the reactor vessel was prossurized to establish flow; a

$$
\text { AI- Al:C-NI:MO- } 12736
$$




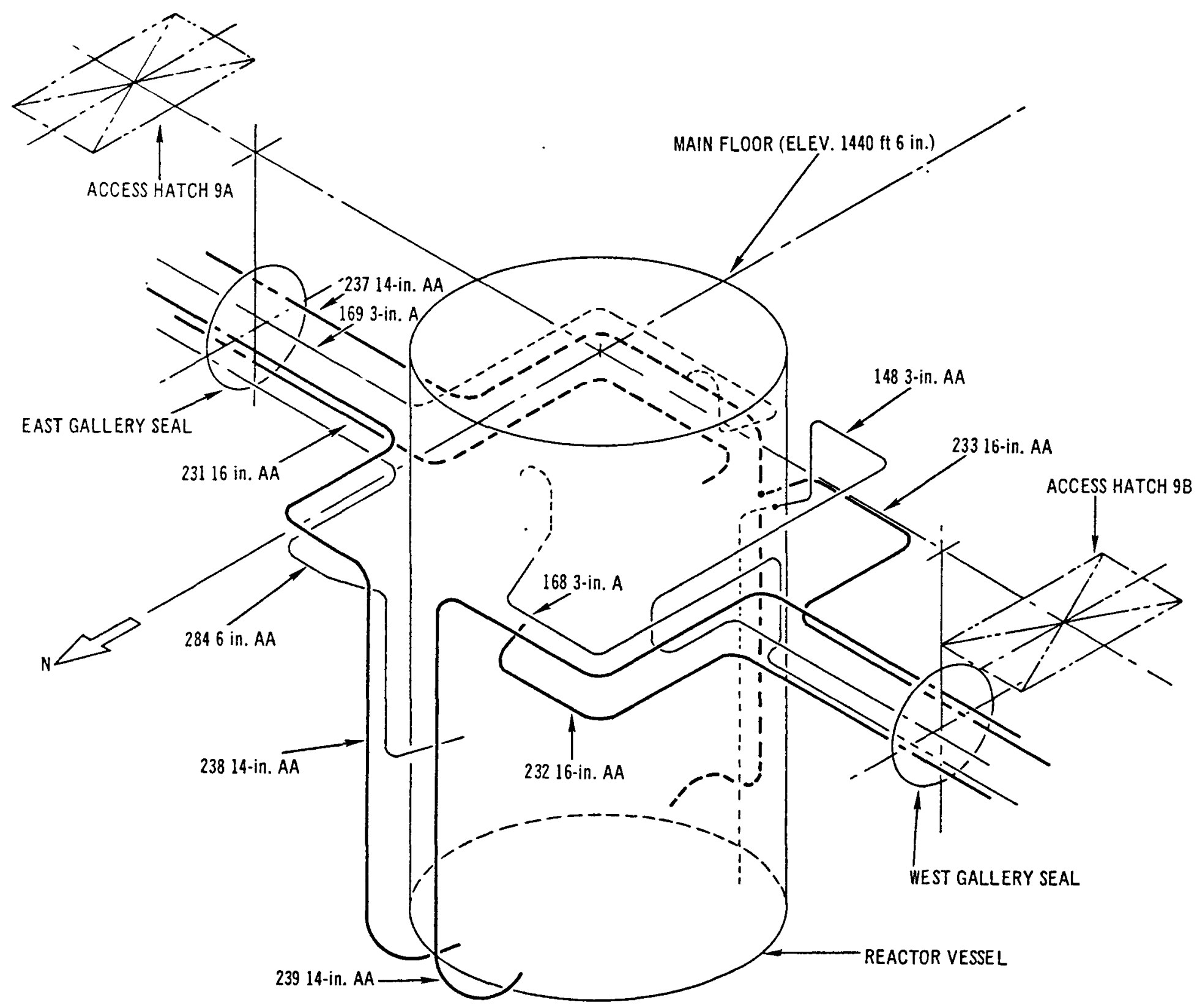

Figure 1. Sketch of Reactor Vessel and Connecting Piping 
Pressure of 8.5 psig was required When the containment drain tank was full, the reactor drain lune was shut of and the containment drain was pressurized to transfer sodjum through the primary sodium drain tank, to the primary sodium storage tank. This operation was repeated until the system ceased to function due to the low sodium level in the reactor vessel. The target level for the operation was 3/8-in. maximum sodium level. Final measurements indicaled that the vessel was drained to a level of about $3 / 16$ in.. near the outside of the vessel bottom. The bottom of the reactor vessel was not perfectly flat; the center portion had a slight bulge making it higher than the outer portion.

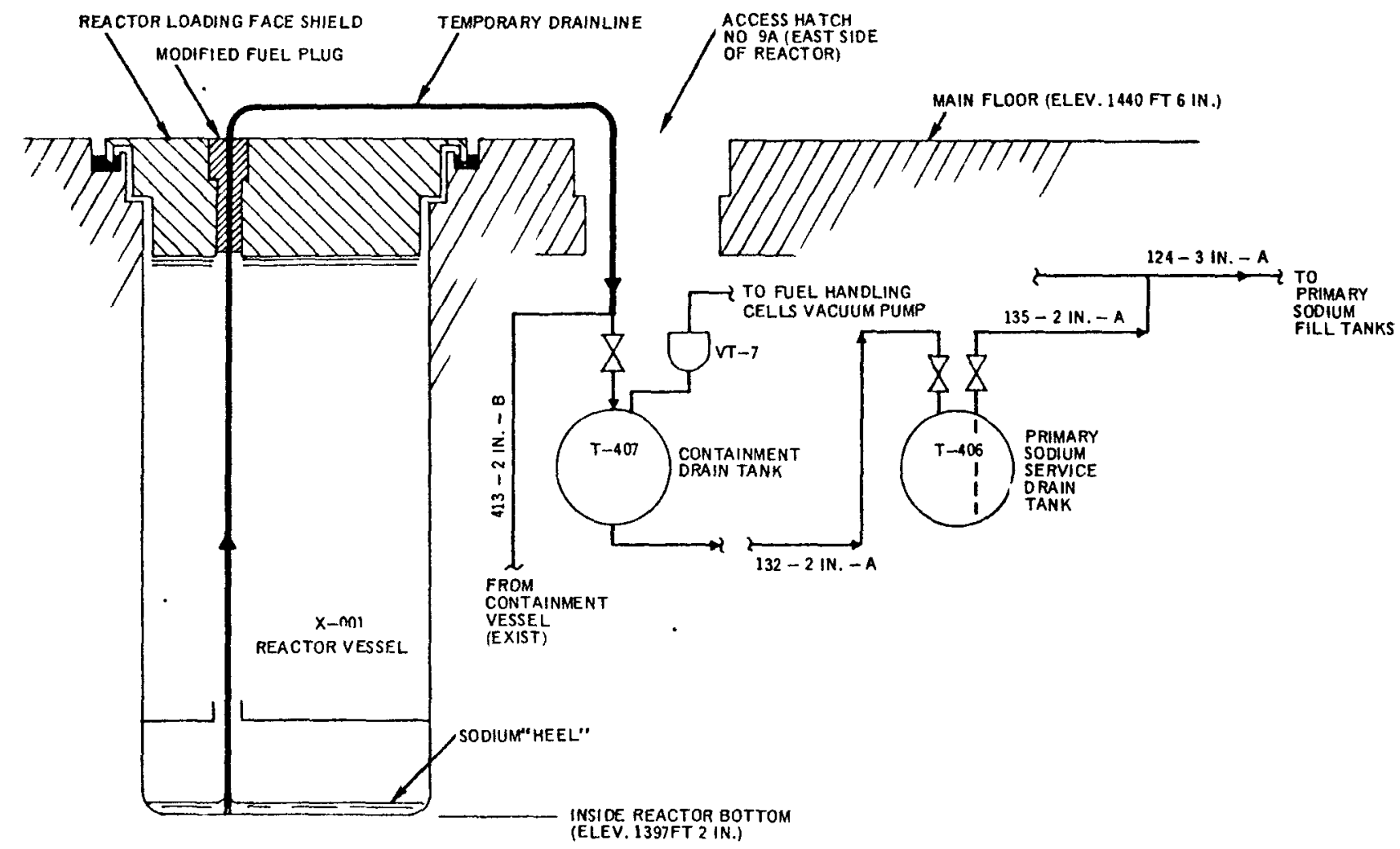

$7709-5406$

Figure 2. Routing of Flow for Draining Sodium "Ifeel" from Bottom of Reactor 


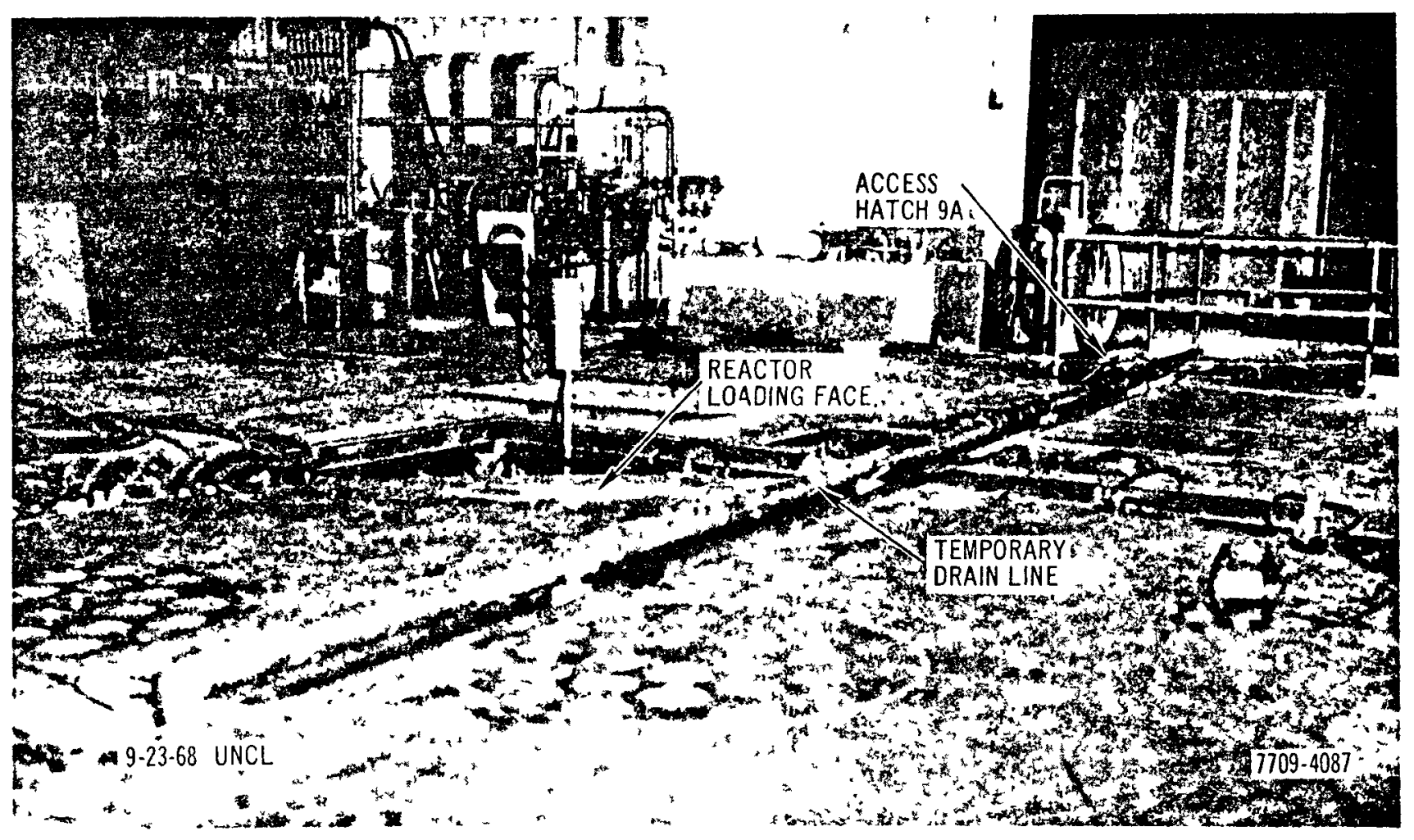

Figure 3. Temporary Reactor Drain Line 


\section{REMOVAL AND SHIPMENT OF BULK SODIUM}

\section{A. GENERAL}

The sodium heat-transfer systems and the sodium service systems were drained into the sodium storage (fill) tanks. These tanks were divided into two groups, primary sodium storage and secondary sodium storage.

The five primary sodium storage tanks were located in a below grade vault, floor elevation $1415 \mathrm{ft} 0 \mathrm{in}$. at the southeast corner of the containment structure, see Figure 4. The primary sodium storage tanks are horizontal cylindrical tanks with dished heads at each end. The overall dimensions are $12 \mathrm{ft}$ OD by $21 \mathrm{ft} 3 \mathrm{in}$. end-to-end. The average sodium loading for the primary tanks was about $110,000 \mathrm{lb}\left(1932 \mathrm{ft}^{3}\right)$ each. Access to the primary tank vault was through a rectangular hatch $22 \mathrm{ft} 6 \mathrm{in.}$ long by $13 \mathrm{ft} 11-1 / 2 \mathrm{in}$. wide in the main floor, elevation $1440 \mathrm{ft} 6 \mathrm{in}$.

The three secondary sodium storage tanks were located in a separate underground vault, floor elevation $1420 \mathrm{ft} 0 \mathrm{in.}$, north of the primary vault. The secondary sodium storage tanks were also horizontal cylindrical tanks with dished heads at each end. The overall dimensions are $12 \mathrm{ft}$ OD by $14 \mathrm{ft} 5 \mathrm{in}$. end-to-end. The average sodium loading for the secondary tanks was about $76,660 \mathrm{lb}\left(1,330 \mathrm{ft}^{3}\right) \mathrm{each}$. Access to the secondary tank vault was through a rectangular hatch, $17 \mathrm{ft}$ long by $14 \mathrm{ft}$ wide, in the main floor.

All of the tanks, primary and secondary, were equipped with electric heaters, thermal insulation, and metal sheathing. The heaters, insulation, and sheathing added about $\mathrm{l} f \mathrm{ft}$ to the diameter of each tank. The addition of heater terminal boxes added about $2 \mathrm{ft}$ to the overall length of each tank. The tanks were set on supports made of structural steel. Since the terminal boxes made the primary tanks longer than the hatchway, a section of concrete was chipped out of one end of the primary tank hatchway.

Plans were made to disconnect the sodium storage tanks from the sodium scrvice systems, remove them from the underground vaulta, and load them onto railroad flat-cars for shipment to their destination. Electric heaters, thermal insulation, and heater terminal boxes were left on the tank. A detailed description of the removal plans is given in Reforence 2 .

$$
\text { AI-AFC-MEMO- } 12736
$$




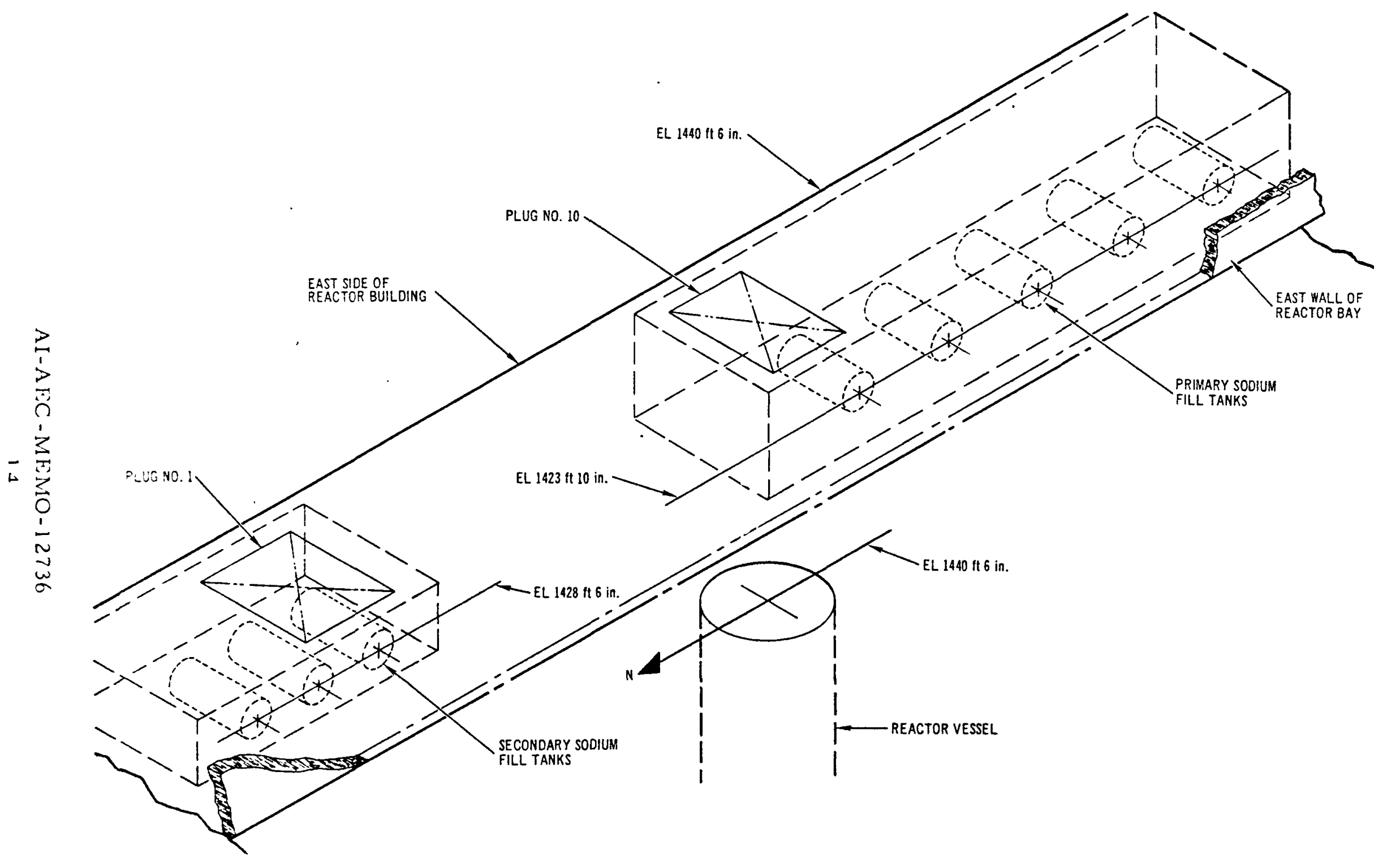

Figure 4. Sketch Showing Location of Primary and Secondary Sodium Storage Tanks 
The secondary tanks were shipped to Chatsworth, California, where they were transfered to trucks and brought to the Liquid Metal Engineering Center (1, MEC) at the AI Santa Susana Facility. The primary tanks were shipped to PNI, at Richland, Washington. The specific activity of the primary sodium was approximately $0.025 \mu \mathrm{c} / \mathrm{gm}$. The source of this activity was sodium-22 which has a 2.58 -yr half-life.

Shipment of the sodium filled tanks was made on ICC Special Permit 4913 which permitted shipment in special liquid sodium storage tanks which did not meet the requirement of Section 73.206 of the ICC Regulations.

\section{B. REMOVAL OF TANKS FROM UNDERGROUND VAUITS}

Preparation for removal of the tanks started with turning off the electric heaters and allowing the sodium to cool and solidify, freezing point $208^{\circ} \mathrm{F}$. After the tanks had cooled, all electrical, instrumentation, and piping connections were disconnected and removed. Piping nozzles on the tanks were sealed by welding. The main floor around the secondary tank vaults was shored up to ensure that there would be no danger of failure due to the heavy load of the tanks and handling equipment. A previous investigation had indicated that the reinforced concrete floor might not be adequate for these heavy loads.

Since the tank supports were not designed for dynamic loading, the supports were reinforced by the addition of structural steel members. The supports were then welded to the tanks, see p. 28 of Reference 2. The tank, support, and tie down arrangement for the railroad cars were designed for a shock load of $1 \mathrm{~g}$ in the fore and aft direction and for repeated loads of $0.5 \mathrm{~g}$ fore and aft, $0.2 \mathrm{~g}$ lateral, and $0.1 \mathrm{~g}$ vertical. The tank supports were also fitted with special lifting eyes to permit handling with cranes, see Figure 4 of Reference 2.

Discussions with the railroad shipping company had indicated that the dynamic loads could be maintained within the above limits by use of cushion underframe cars, by limiting train speeds to $40 \mathrm{mph}$ on straight tracks and $30 \mathrm{mph}$ on curves, and $b$ limiting coupling and switching speeds to $1 \mathrm{mph}$.

The original removal plans had called for removal of the secondary tanks through the cast wall of the building, or through the roof, once they had been lifted through the hatch; however, with his available equipment, the rigging contractor wat able to slide these tanks south, over the primary tank vault and

$$
\text { AI-AFC-MFMO- } 12736
$$




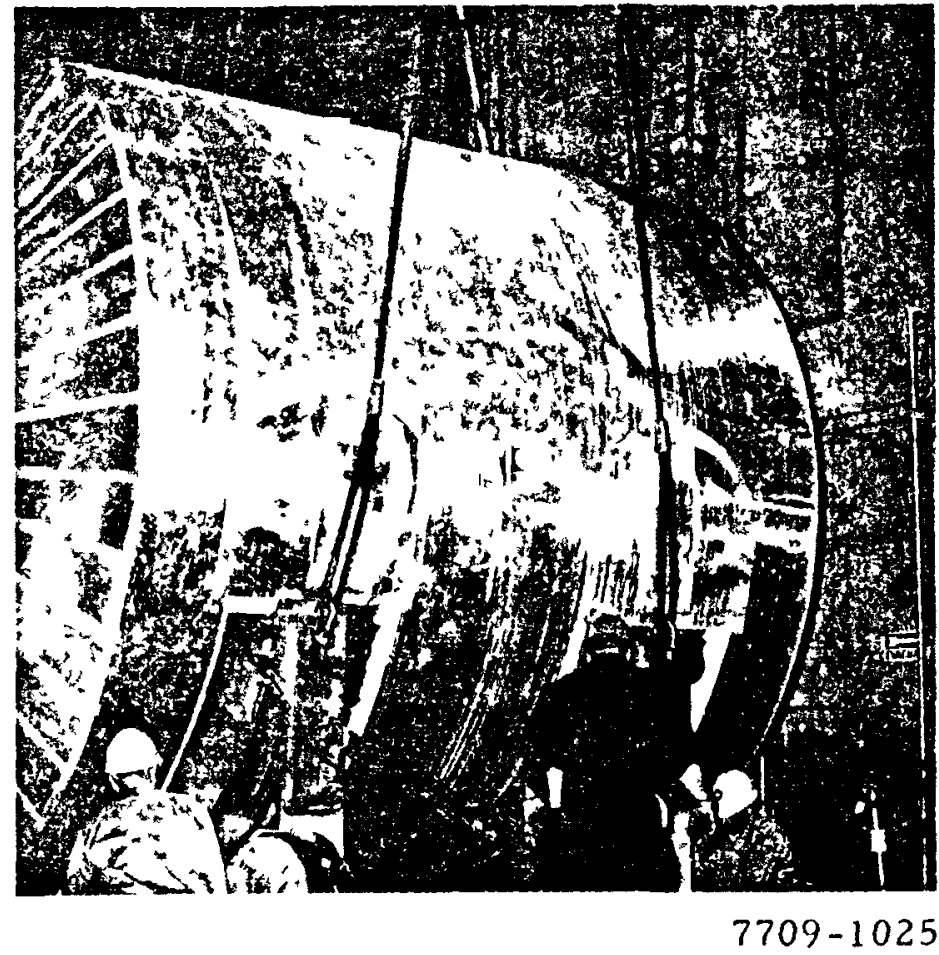

Figure 5. Secondary Sodium Storage Tank Removed from Underground Vault at HNPF

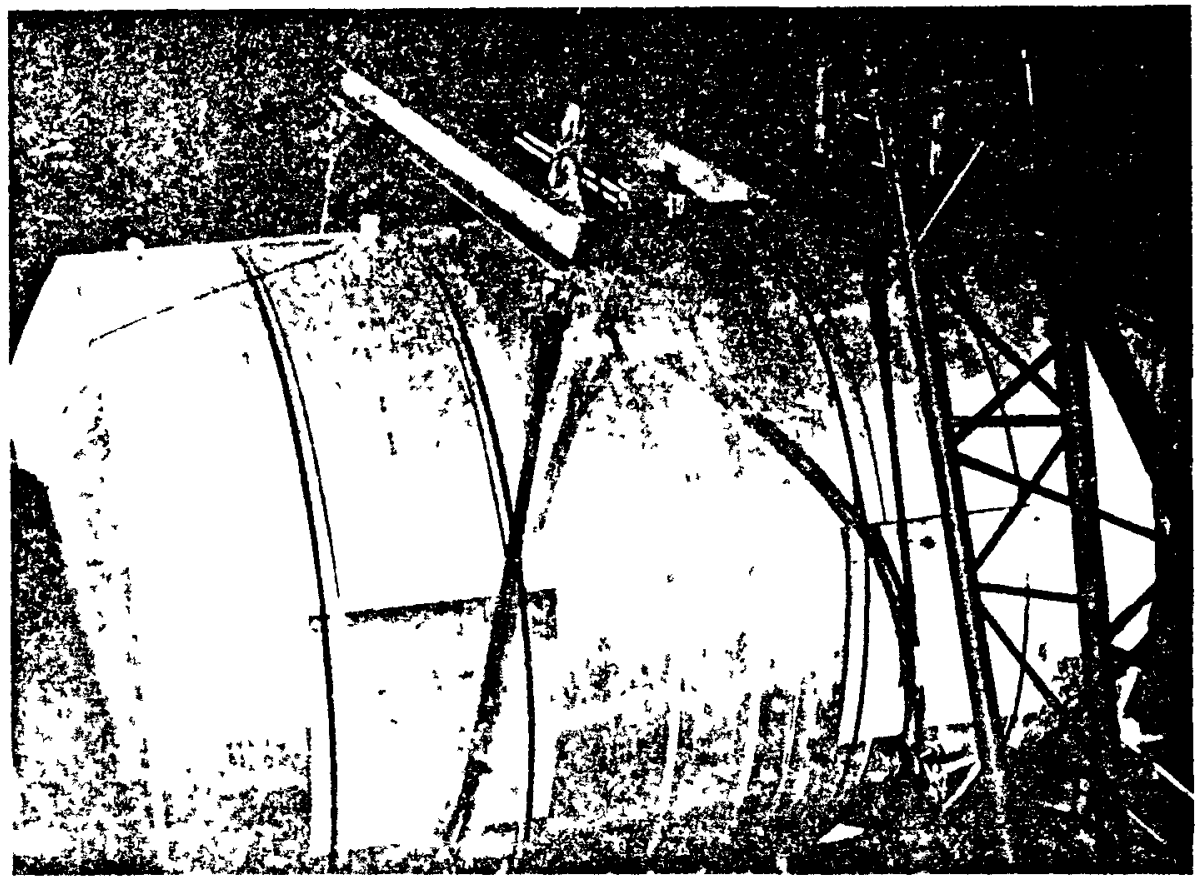

$7709-1055$

Figure b Pram, hodum Storage Tank Being Remused tom Luckereresund Vault at $\mathrm{HNPF}$ 
out of a roll-up door at the south end of the building where a railroad siding is located. In order to accomplish this, it was necessary to first remove some above grade equipment no longer required from the plant nitrogen and helium systems. Figure 5 shows the secondary sodium storage tank just after being removed from the underground vault.

The primary tanks were removed from the underground vaults in a manner similar to that for the secondary tanks. These were the heaviest tanks weighing about 74 tons each. Figure 6 shows the primary sodium storage tank being removed from the underground vault.

During the removal operation, some minor damage was sustained by the thermal insulation and sheathing. The damage was not too extensive to permit easy repair and operation of the electric heaters when the tanks reached their destination.

\section{LOADING OF TANKS ON RAILROAD CARS}

The general arrangement for loading of the sodium storage tanks on railroad flat-cars is shown in Figure 5 of Reference 2. The cars were previously prepared with oak cribbing and ballast for the primary tanks (not shown in Figure 5 of Reference 2) and the tanks were loaded as they were removed from the building; one tank was loaded onto each car. As previously mentioned, cushion undergrame cars were used to reduce the dynamic loads during transit. Since the tanks were wider than the car beds, it was necessary to select cars with beds at least 47 in. above the rails to avoid contact with trackside docks and other obstructions enroute.

The cars used were 90 -ton bulkhead flat cars, series 92500 to 92599 , with a rail load limit of $263,000 \mathrm{lb}$. The cars were equipped with cushion underframes and antifriction bearings. For the primary tanks, the high center of gravity of the sodium-tank-plus-car-bed required the use of ballast, gravel loaded into cribs at each end of the car, to lower the center of gravity. About $34,300 \mathrm{lb}$ of ballast was used on each car. Ballast was required to reduce the load eccentricity at the bearing between the wheel trucks and car bed when the car was sitting on a super-elevated curve. The ballast was added to keep this eccentricity less than one-third of the total bearing width.

$$
\text { AI-AEC-MEMO- } 12736
$$


The secondary tanks did not require lowering of the center of gravity; therefore, no ballast was used Loading and shipping of the primary and secondary sodium tanks is shown in Figures 7 through 11.

\section{SHIPPING OF T ANKS}

The cars with the sodium tanks were spotted at the forward end of the train, near the engine. This location was selected to minimize shock loads due to accumulative coupling slack during acceleration and deceleration. The train with the five primary sodium tanks, which went to Hanford, Washington, was accompanied by two messengers whose duty it was to inspect the cargo during stops and to give directions concerning the safe treatment and handling of the sodium tanks in the event of an accident. This last function would be particularly important in the event of a fire or rupture of a sodium tank.

No messengers were used on the train with the three secondary sodium tanks which went to Chatsworth, California Inspection of the cars after arrival showed some slight loosening of the turnbuckles but not sufficient to permit load shift. The slight loosening was attributed to "seating" of the turnbuckle anchors to the car bed by vibration during transit. Since this was the first shipment made, additional precautions were taken with the primary tanks to ensure that all tie-downs were seated pror to shipment.

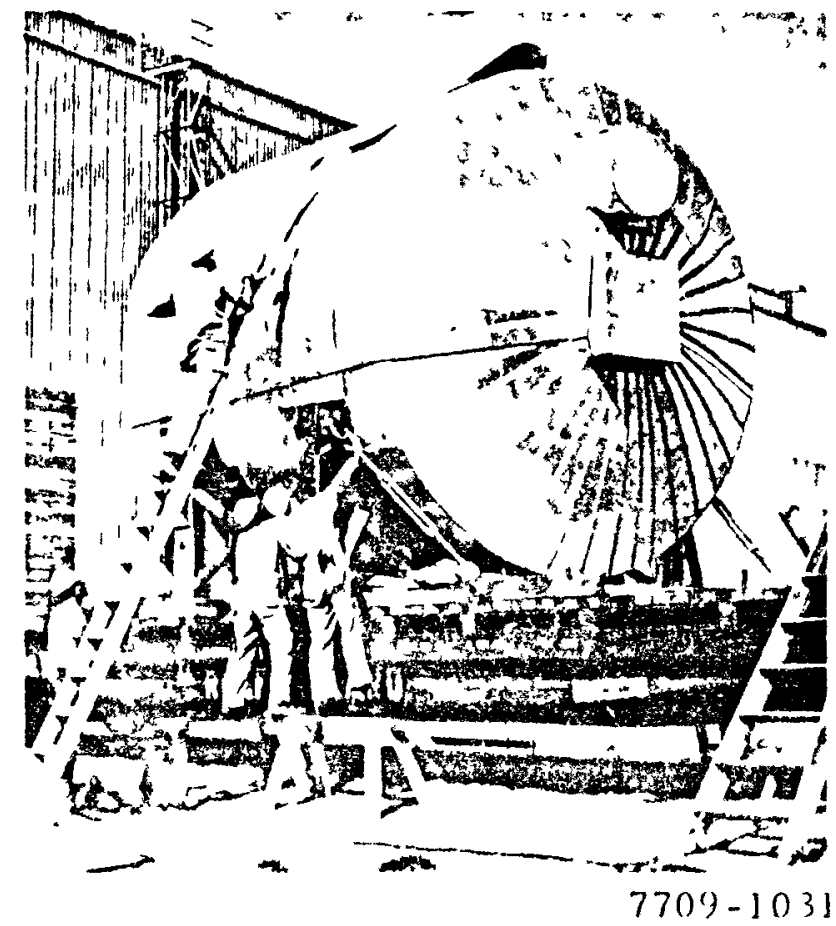

Figure 7. Secondary Sodium Storage Tank Being Anchored

to Railroad Flatcar in Preparation for Shipment 


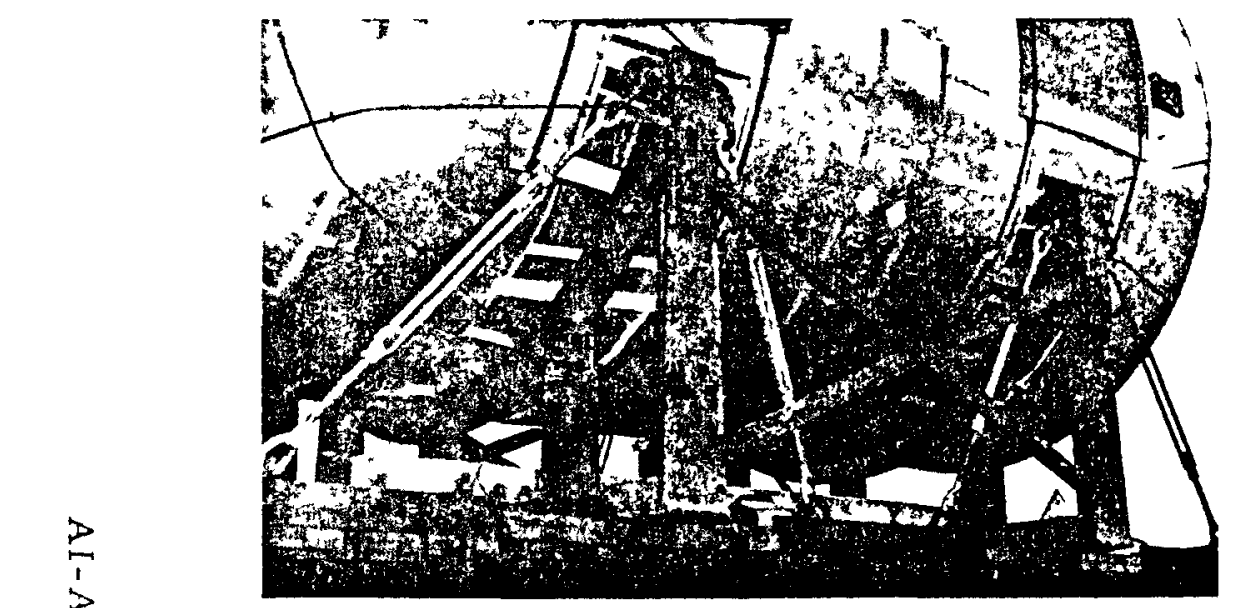

$7709-1048$

a.

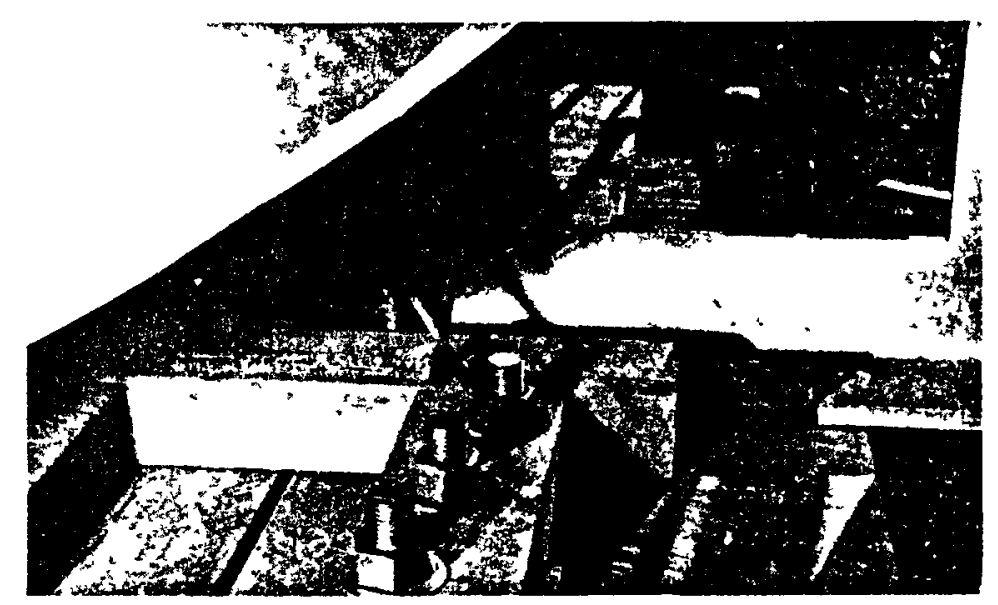

c.

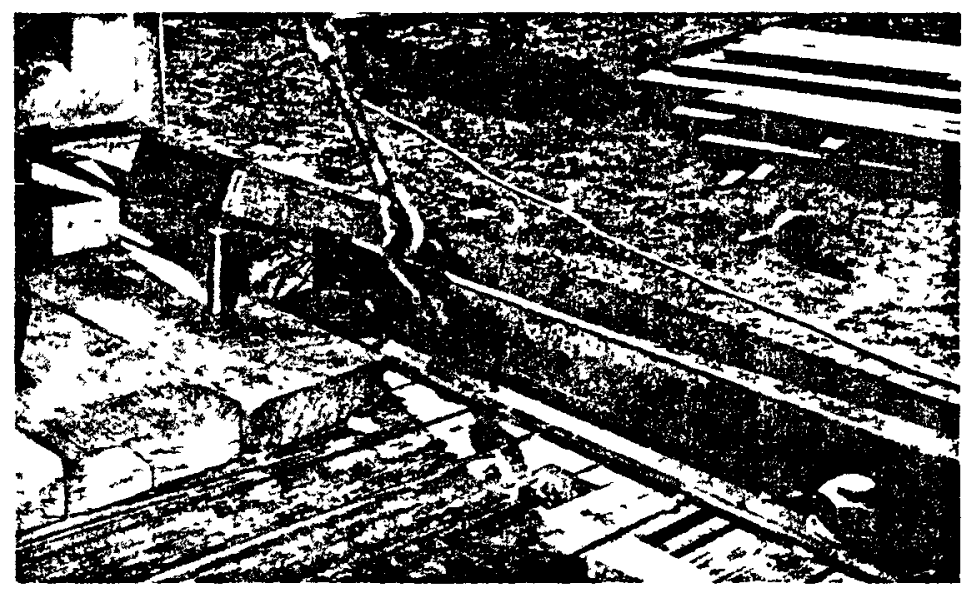

b.

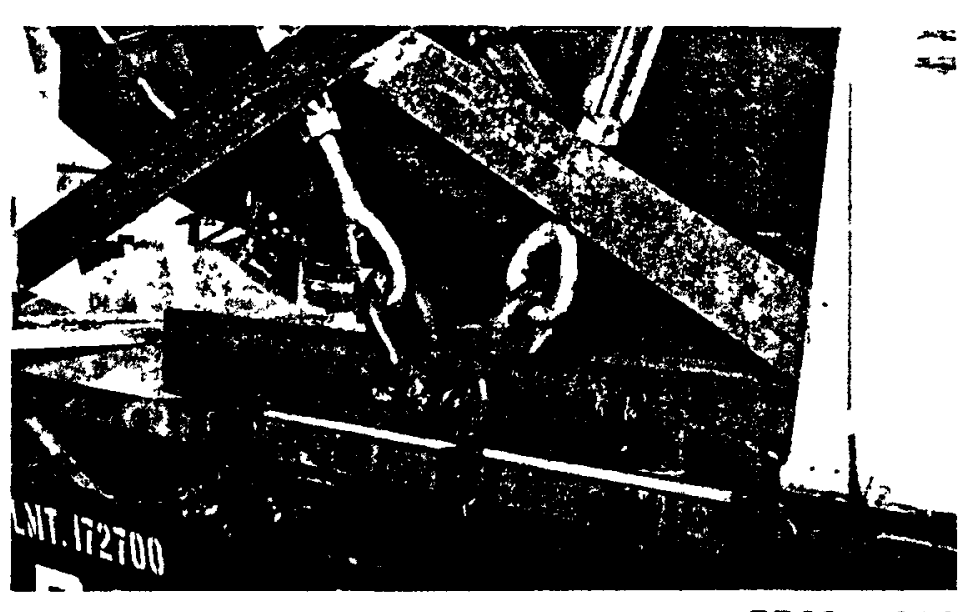

d.

Figure 8. Typical Tiedown Arrangement and Details Used for Shipping Sodium Tanks 


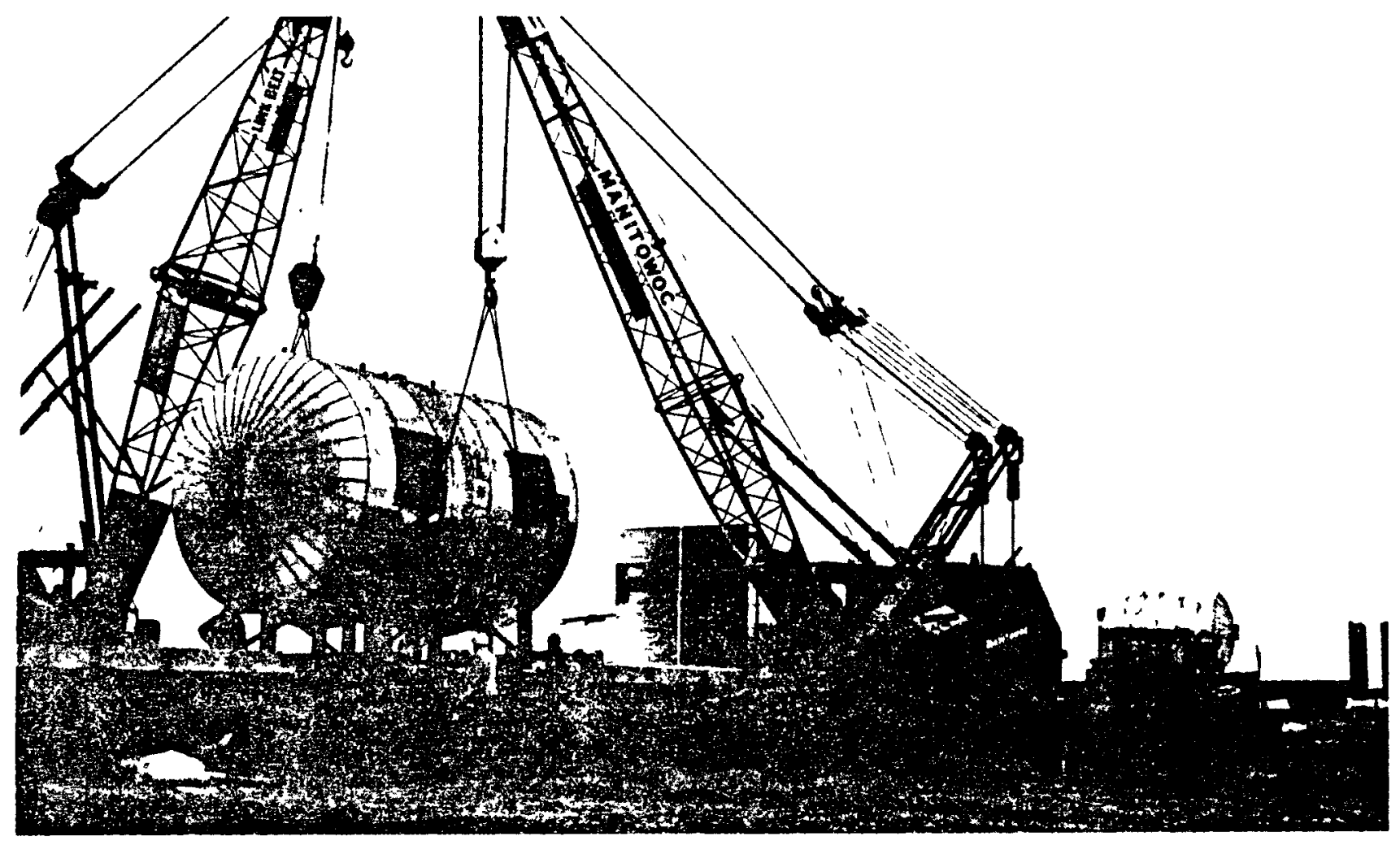

a.

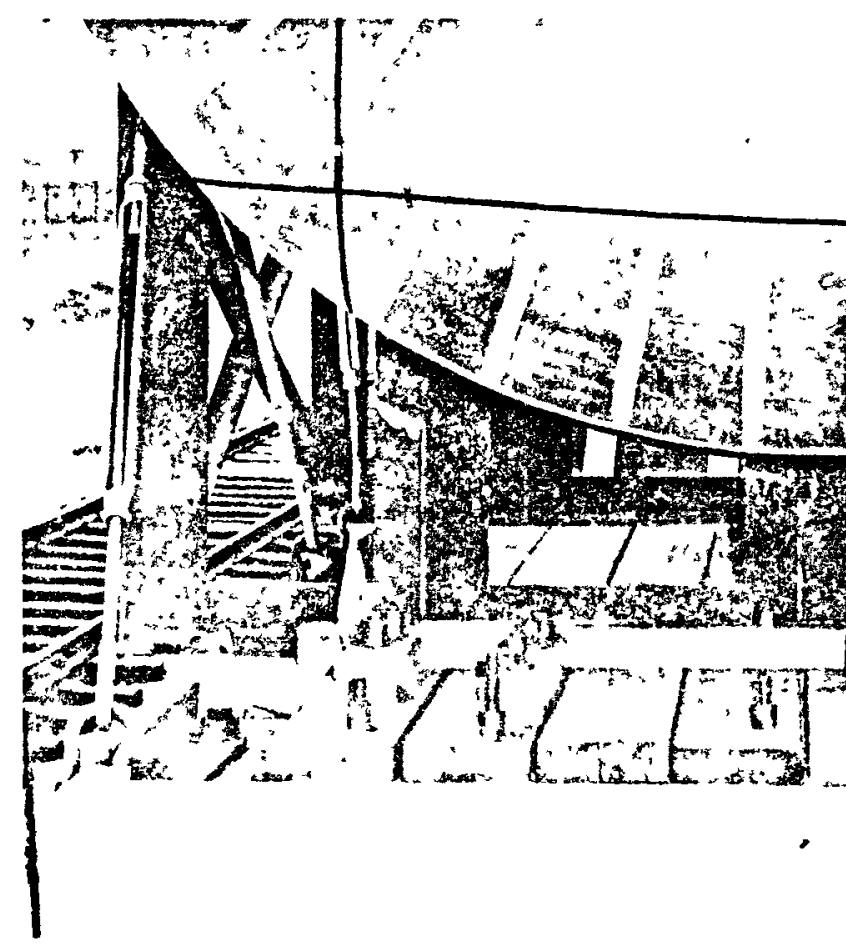

b.

$7709-1041$

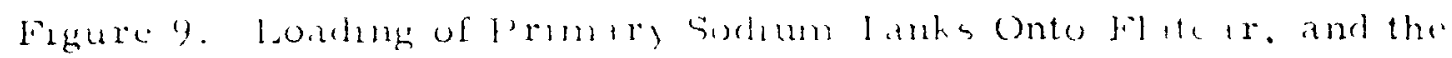
Ballast Arrangement 


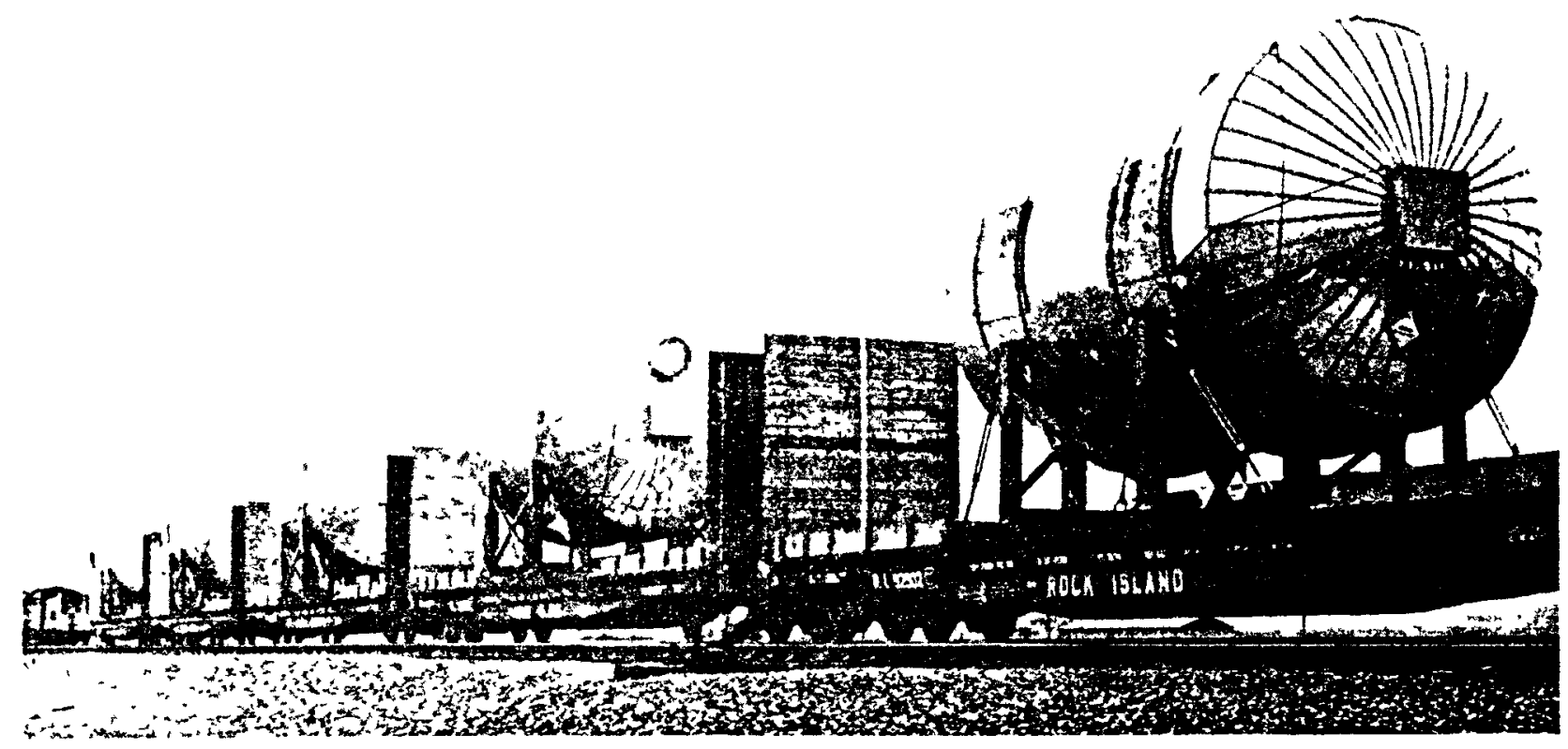

a.

$7709-1061$

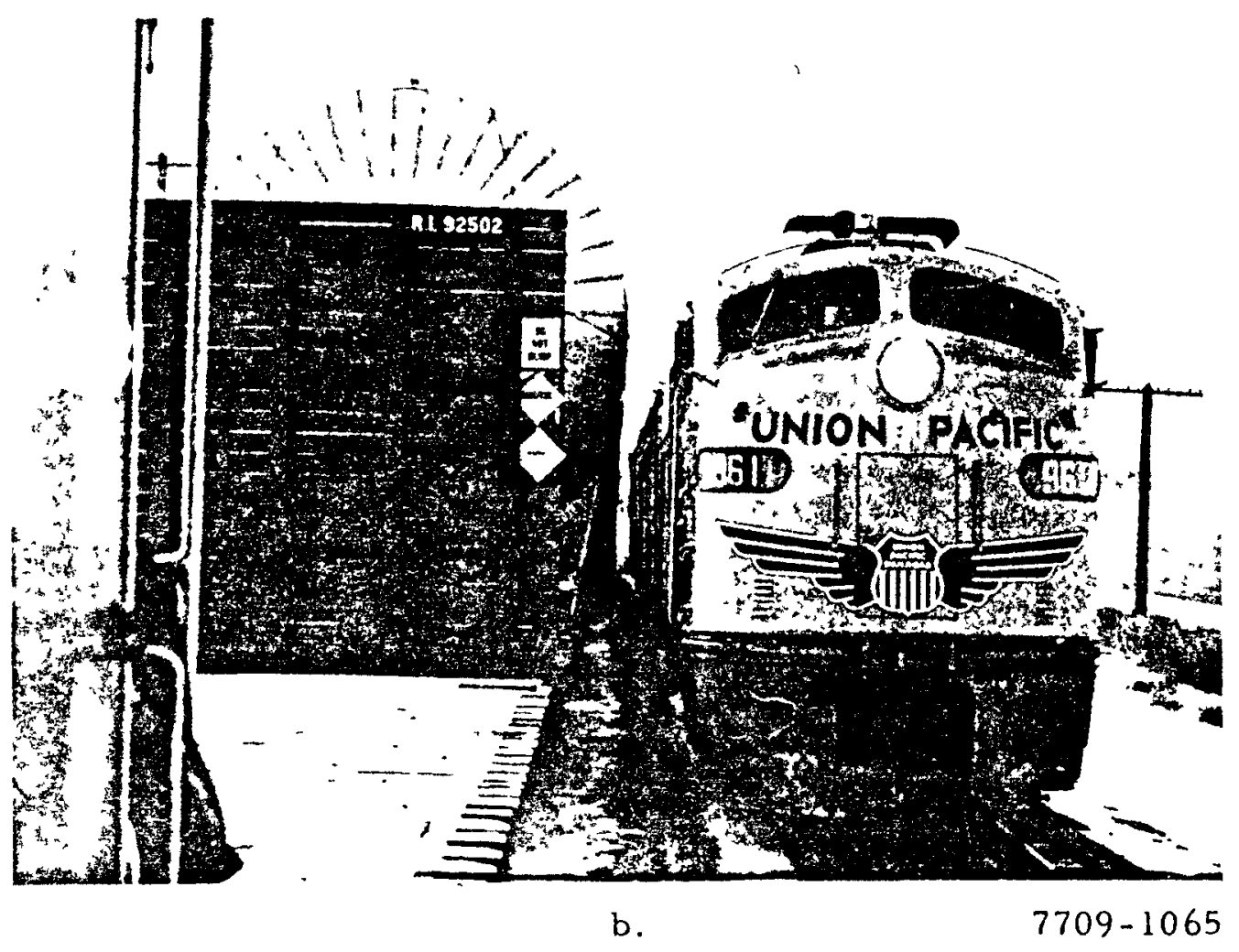

Figure 10. Rail Transport of Primary Sodium Tanks, and Trackside Clearance

$$
\text { AI-AEC-MEMO-12736 }
$$



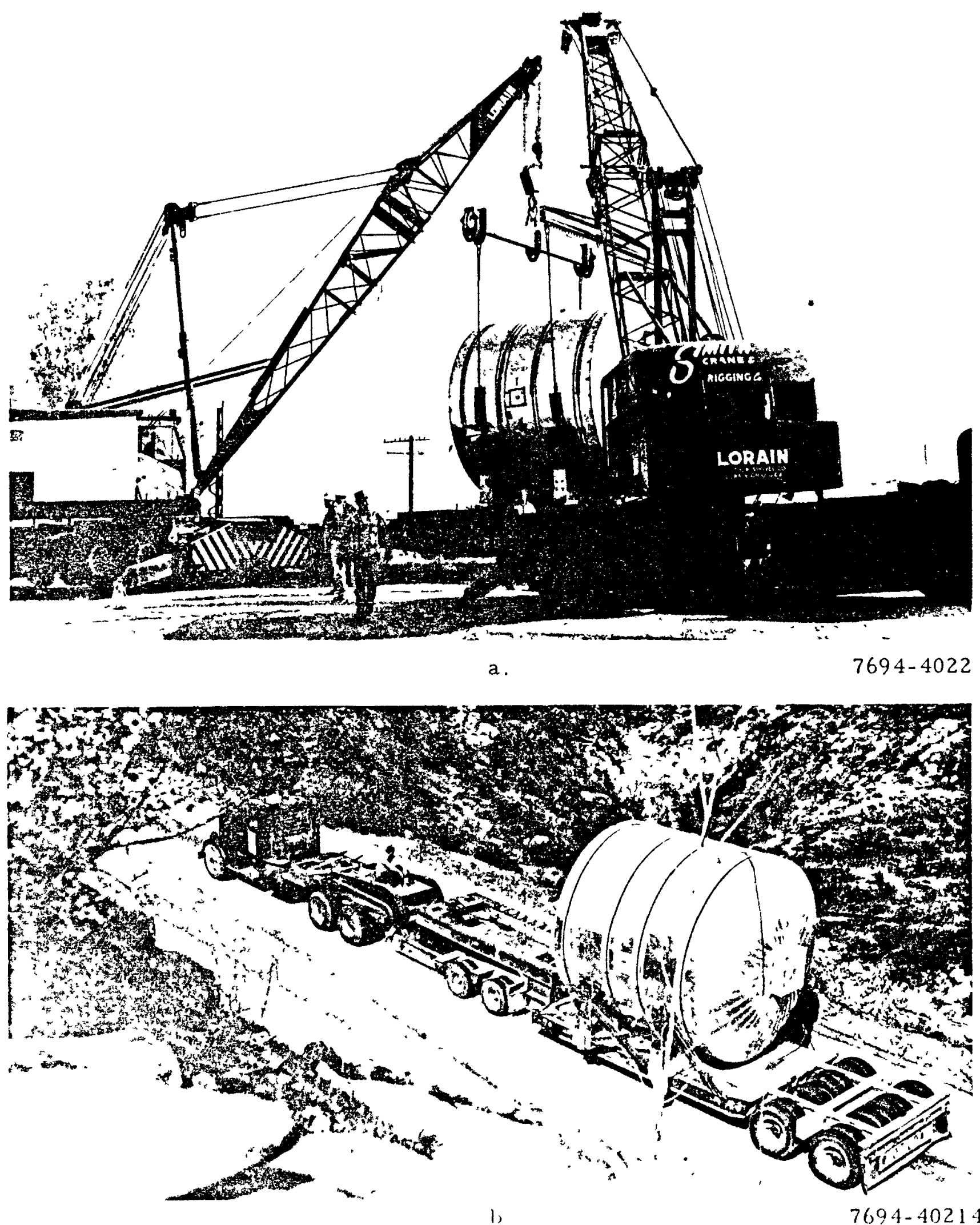

Figure 1]. Unluading Sceondary Sorlum Tunk at Chatsworth, and Truck Transport to Santa Susana 


\section{DISPOSAL OF SECONDARY MAIN SODIUM PIPING}

A. GFNERAI.

The disposal of the secondary main sodium piping was performed in accordance with HNPE Retirement Activity Specification No. 6, "Reaction of Residual Secondary Sodium and Retirement of Secondary Sodium Systems, " and Retiremeni Detailed Procedure 6-1, "Isolation of the Secondary Sodium Service System and Disassembly of the System."

\section{B. REMOVAL OF SECONDARY SODIUM PIPING}

In preparation of separating the sodium piping from the secondary system, it was necessary to remove all insulation, heaters, and reflectors from the sodium pipes and secondary sodium system components. The insulation was buried on site after removal from the system. The reflectors and heaters were placed in the scrap yard.

The sodium pipe of the secondary sodium system was separated from the system components, such as the pumps, intermediate heat exchanger, valves, etc. before being cut into various lengths for removal from the pipe ways and system component module bay areas. As a section of pipe was separated from a system component, a plate was welded over the opening in the system component and a plastic cap was taped over the open end of the pipe to keep any sodium remaining in the system from reacting with the atmospheric moisture.

The pipe, after separation from a system component, was cut into various lengths. The length of each pipe section removed depended on the opening of the area where the pipe was being removed and the location in respect to the next component in this system; see Figure 12 which shows a typical loop and the approximate locations from which sodium pipe was cut.

The sections of pipe removed from the secondary sodium system were removed from the pipeways with the reactor high bay crane and stored in the reac10r high bay until sufficient piping was available for cleaning. 


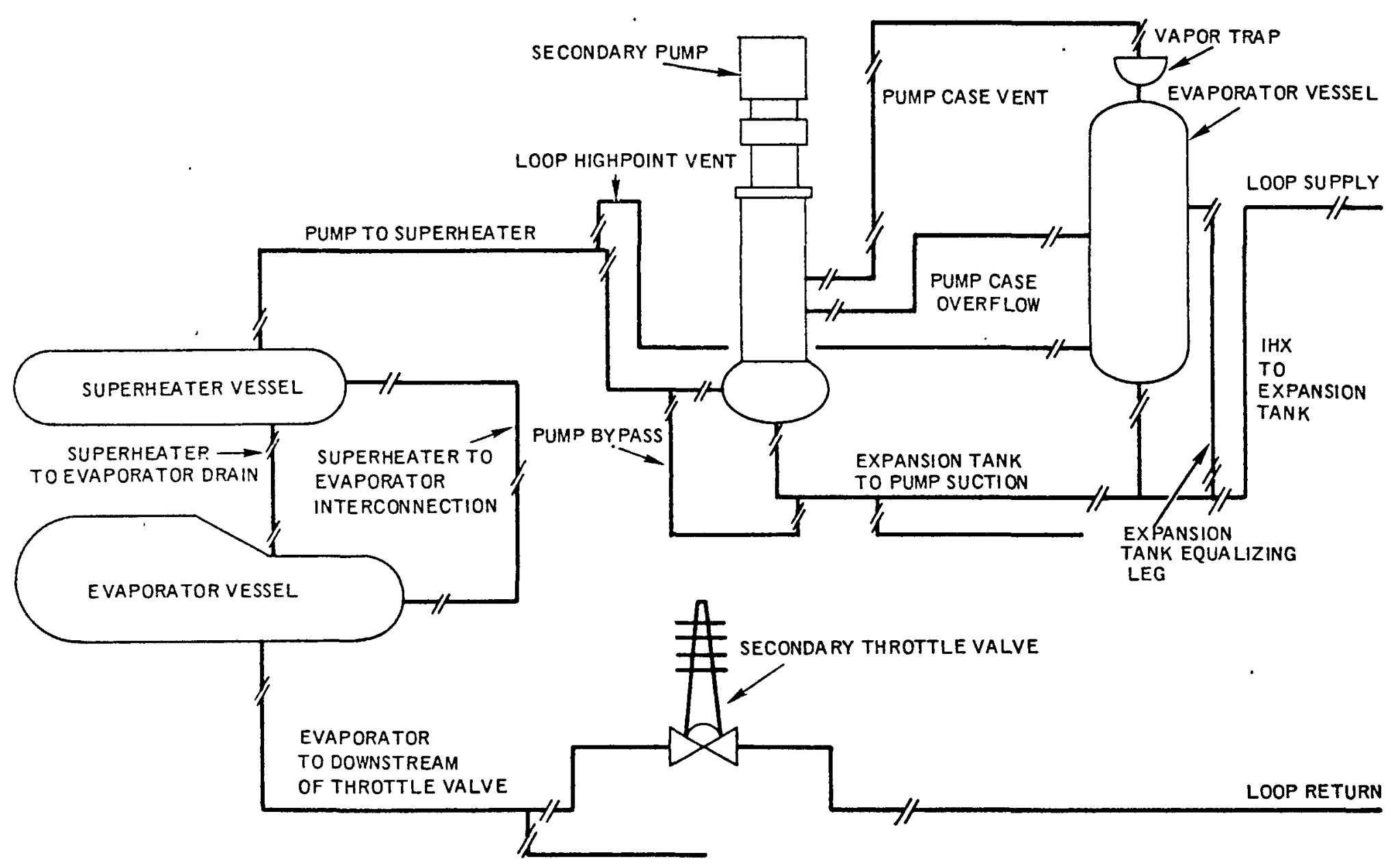

Figure 12. Typical Sodium Loop Isolation Diagram 


\section{CLEANING OF SECONDARY SODIUM PIPING}

The secondary sodium piping that had previously been removed from the secondary sodium system and stored in the reactor high bay was transferred to an area south of the reactor building preparatory to the operation of cleaning each section of pipe.

The steam cleaning and sodium burning facility construction was incomplete at the time the secondary sodium system piping was available for cleaning; therefore, the secondary system piping was washed in a controlled area south of the reactor building on a concrete pad by Consumers Public Power District (CPPD) personnel. The personnel performing the operation wore flame retardant clothing and face shields.

A truck with an "A" frame hoist transferred one section of pipe from the storage area to the concrete pad where the plastic cap on one end of the pipe was removed. A fire hose was then used to flood the pipe from the open end. After the pipe was completely clean and the sodium had been reacted, the section of pipe was surveyed for contamination and then transferred from the concrete pad to the scrap yard as shown in Figure 13 to await final disposal.

All of the main secondary sodium piping was free of contamination after washing and sodium removal. The pipe was then available for sale as scrap.

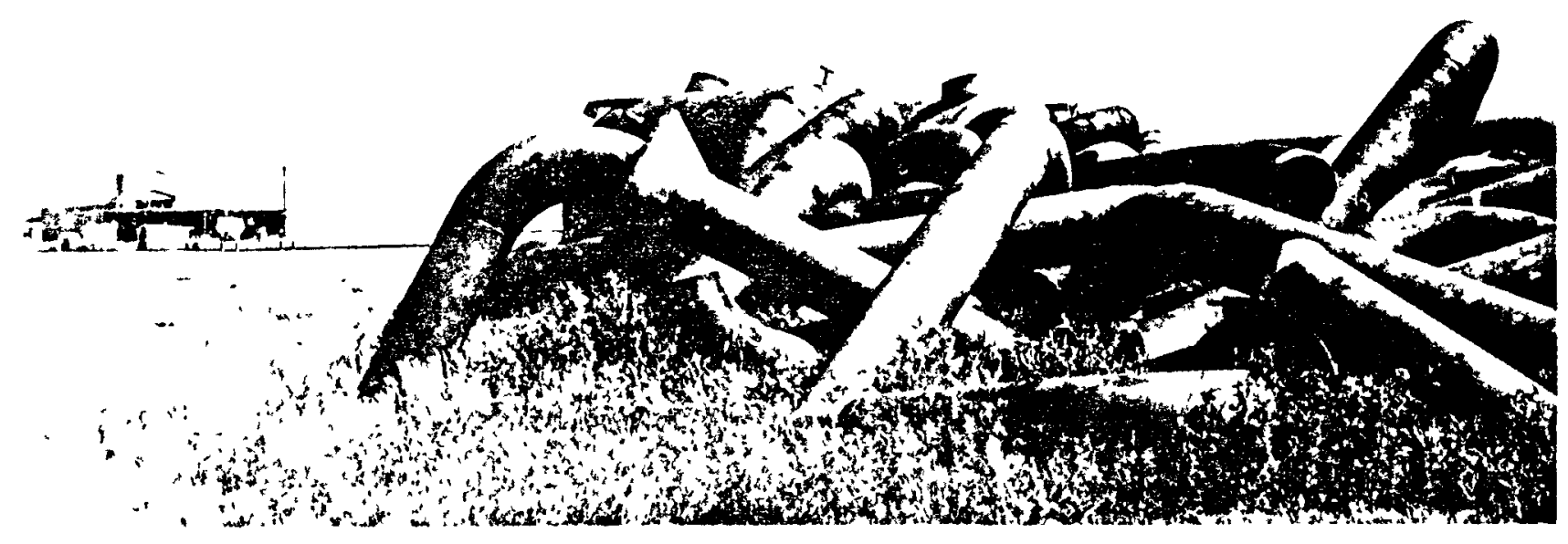

$7709-4077$

Figure 13. Main Sodium Plping in Scrap Pile After Cleaning 
$$
\text { . }
$$ 


\section{REACTION OF RESIDUAL SODIUM IN PRIMARY HEAT TRANSFER SYSTEM}

The residual sodium in the primary, heat-transfer system was reacted with steam, in a nitrogen atmosphere. The operation was carried out in two parts. First, the residual sodium in the reactor vessel and piping from the vessel to the gallery seal was reacted. Next, the residual sodium in the primary heat transfer piping including the pump casings was reacted.

\section{A. SELECTION OF REACTION}

Since sodium is a relatively active metal, a number of chemical reactions were possible. The criteria for selection of a particular reaction process was that it had to be controllable, both in increasing and decreasing the reaction rate, and that the reaction products could be safely handled without damage to the reactor vessel or injury to personnel.

Control was a particularly sensitive problem since the reactor vessel contained some 7000 cubic feet of free space. Once this space is filled with a reactive agent or reaction product, controllability could be questionable.

Sodium reactions with oxygen (air), water (liquid and steam), carbon dioxide, and alcohols were investigated. Also, reactions with humidified air and humidified nitrogen were investigated, see Section IV of Reference 3.

The first experiments indicated that sodium reacts slowly with natural (no humidity controlled) air. In fact, the carbon dioxide in air might form a crust of sodium carbonate which would isolate the sodium from the air and stop the reaction before it was completed. Continued experimentation, see Appendix II of Reference 3. in this direction soon demonstrated the potential hazards concommitent with this method. In one of the tests, a 2 -in. layer of sodium at the bottom of an 18-in. diameter cylindrical vessel was used. Atmospheric air was circulated through the vessel. After 19 days of a relatively slow reaction. with sodium hydroxide building up in a layer over the sodium. the vessel exploded; see Reference 7. The violenee of the explosion indicated that it was apparently due to hydrogen cletonation. Repeated tests using smaller sodium samples indicated that an explosion was highly probable if the depth of the original sodum layer is more than approximately $1 / 4 \mathrm{in}$.

$$
A I-A I:(:-N H \cdot M O-12736
$$


Continued investigation disclosed the mechanism through which the explosive condition is created. The initial reaction at the sodium-air interface is a straight forward oxidation reaction with the oxygen of the air and the water vapor in the air.

$$
\begin{gathered}
2 \mathrm{Na}+\mathrm{O}_{2} \rightarrow \mathrm{Na}_{2} \mathrm{O}_{2} \\
2 \mathrm{Na}+2 \mathrm{H}_{2} \mathrm{O} \rightarrow 2 \mathrm{NaOH}+\mathrm{H}_{2} \uparrow
\end{gathered}
$$

As the reaction continues, the solid reaction products, $\mathrm{Na}_{2} \mathrm{O}_{2}$ and $\mathrm{NaOH}$, build up in a laye $\mathbf{r}$ over the sodium. Both of these compounds are hygroscopic and tend to absorb moisture from the atmosphere and form an aqueous solution. Once the aqueous solution covers the layer of sodium, the sodium is prevented from reacting with the atmosphere. At the air-hydroxide interface, more water is absorbed from the atmosphere, creating a dilute solution.

$$
\begin{aligned}
& \mathrm{H}_{2} \mathrm{O}+\left[\mathrm{x} \mathrm{NaOH}+\mathrm{yH}_{2} \mathrm{O}\right] \rightleftarrows\left[\mathrm{x} \mathrm{NaOH}+(\mathrm{y}+1) \mathrm{H}_{2} \mathrm{O}\right] \\
& \text { Air Aqueous Hydroxide Diluted Hydroxide } \\
& \text { - Moist. Layer Solution }
\end{aligned}
$$

The direction of the reaction depends on the temperature, concentration of the solution, and the vapor pressure of moisture in the atmosphere.

At the interface between the sodium and the sodium hydroxide solution, water from the solution reacts with the sodium and produces hydrogen which bubbles out through the solution to the atmosphere.

$$
\begin{aligned}
& \left(x \mathrm{NaOH}+(\mathrm{y}+1) \mathrm{H}_{2} \mathrm{O}^{-}+2 \mathrm{Na} \cdot\left[(\mathrm{x}+2) \mathrm{NaOH}+(\mathrm{y}-1) \mathrm{HI}_{2} \mathrm{O}\right]+\mathrm{H}_{2} \uparrow-\right. \\
& \text { Diluted Hydroxide Sodium Concentrated Hydroxide } \\
& \text { Solution Layer Solution }
\end{aligned}
$$

As indicated in Equations 5.3 and 5.4, the air side of the aqueous hydroxide layer is more dilute than the sodium side. This causes a concentration gradient and continual transfer of water from the air to the sodium. The reaction is slowed by a reduction of moisture in the atmosphere and may eventually stop if 
the vapor pressure of the water over the hydroxide solution is greater than the vapor pressure of water in the air. In such case, water would leave both sides of the aqueous layer causing the hydroxide to cake into a crystalline mass; for example, if the hydroxide layer is at $40^{\circ} \mathrm{C}\left(104^{\circ} \mathrm{F}\right)$ with a concentration of $65 \mathrm{gm}$ $\mathrm{NaOH} / 100 \mathrm{gm} \mathrm{H}_{2} \mathrm{O}$ at the air surface, the equilibrium water vapor pressure above this mixture is $13.2 \mathrm{~mm} \mathrm{Hg}$; see Table 3-27 of Reference 4. If the partial pressure of water vapor in the overlying air is less than $13.2 \mathrm{~mm} \mathrm{Hg}, 25 \%$ relative humidity at $40^{\circ} \mathrm{C}$, water evaporates from the hydroxide solution to the atmosphere; at the same time, water from the solution reacts with the underlying sodium and causes a net drying effect in the hydroxide layer.

The foregoing system is subject to a physical instability, especially if the original sodium layer is deep. The hydroxide solution is more dense than the underlying sodium; and during the reaction process, fragments or globules of sodium detach from the main body and float to the surface. This results in an increased reaction rate due to the increased sodium surface area and the higher wate $r$ concentration at the surface of the hydroxide layer. The increased reaction rate is accompanied by an increase heat in production which is eventually sufficient to ignite the hydrogen when it escapes into the air.

The results of the previously mentioned tests using smaller amounts of sodium indicate that the maximum stable depth for sodium is about $1 / 4 \mathrm{in}$. This value may be subject to variation with temperature and humidity. Physical instability did not occur with those samples which were prepared in a manner permitting the hydroxide layer to drain away as it was formed; therefore, the reaction followed Equations 5.1 and 5.2.

Based on the test data and analysis of results, it was decided that the residual sodium in the HNPF primary system could be chemically reacted by using an inert gas and controlled humidity. In this manner, the risk of an explosion can be avoided. The most hazardous situation would be a rapid release of hydrogen and heat due to the physical instability problem.

Nitrogen was selected because of its relatively low cost. The nitrogen was heated and mixed with steam under temperature and pressure conditions which avoids condensation and subsequent addition of liquid into the reactor. The steam was readily available from the adjacent steam power plant. Further

$$
\text { AI-AFC-MFNO-12736 }
$$


protection against fire or explosion was provided by keeping the hydrogen concentration in the effluent nitrogen below that which would support combustion if the hydrogen-nitrogen mixture were mixed with air. The reaction was controlled by controlling the steam and nitrogen flow rates. Temperatures and pressures selected were within the safe operating capability of the equipment.

The efficacy of the steam-nitrogen process had previously been verified by tests in which a scaled down simulation of the reactor vessel was used, see Reference 5. These tests show that sodium layers with thickness similar to those which existed in the reactor vessel could be completely reacted by using steam-nitrogen mixtures with steam concentrations between 10 and $80 \%$ by volume. Also determined by the tests were that thick sodium layers, approximately 2 in. thick, are subject to physical instability and that this results in an inc reased reaction rate.

Other methods of chemically reacting sodium had been investigated and showed either practical or economic disadvantages when compared to the steamnitrogen method. These disadvantages became apparent early in the studies obviating test work. Some of these methods and problems follow.

1) Reaction by Water Spray in a Nitrogen Atmosphere

Sodium deposits due to condensed sodium vapors were expected in areas of the reactor vessel such as on top of the loading face shield and a round the Cerrobend seal; these would not be readily accessible to direct spray.

2) Reaction by Alcohol

Flooding of the reactor with alcohol would be expensive and would be a fire hazard due to the amount of combustible vapors. The fire hazard would be increased by the presence of hydrogen generated by the reaction. The use of alcohol vapors would require a complex recirculation system in order to conserve alcohol and to prevent the escape of fumes which are Loxic and flammable.

3) Reaction by Dry Carbon Dioxide

High temperatures which are required for reaction with dry carbon dioxide would require the installation of extensive heating cquipment. Such temperatures might also damage the reactor vessel. 
4) Reaction by Moist Carbon Dioxide

This reaction produces sodium hydroxide as an intermediate product and sodium carbonate as a final product. The carbonate is not readily soluble in the hydroxide (Reference 6) and could form a crust which would seal the gas atmosphere from the remaining sodium.

\section{B. PREPARATION OF HEAT TRANSFER SYSTEM}

After draining most of the residual sodium from the reactor vessel, the reactor vessel and the three heat transfer loops were prepared for the steaming operation. First the primary sodium block, throttle, and check valves were removed. These valves were in the main loop piping between the reactor and the rest of the primary heat transfer system, see Figure 14. The valves were located on the east and west sides of the reactor, just outside of the diaphragm seals between the reactor cavity and the primary pipe gallery. A 9-ft $\times 14-\mathrm{ft}$ hatchway in the main floor on each side of the reactor provided access for valve removal.

Modified pipe caps fitted with 2 -in. stub ends for future connection to the steaming system were welded to the primary sodium piping where the valves had been removed, see Figures 15 and 16. Sodium pipes leading to and from the intermediate heat exchangers (IHX's) were cut and capped near the IHX locations. A 4-in. bypass line was installed between the cut end of each pump discharge line and the corresponding reactor return line, see Figures 17 through 20. Connections from the primary sodium pumps to the cover gas system and the balancing legs were also cut and capped. The pump covers were reinforced by welding structural steel to the cover plates and nozzles for attachment to the steaming system, and pressure gages were installed in the cover plates.

Six sodium sample holders, each having two cups for holding sodium samples, were fabricated and hung from selected fuel plugs in the loading face shield. These holders are shown in Figure 1 of Appendix C. Figure 2 of Appendix $C$ shows the installation locations. Sodium samples were put in these holders for future inspection after the steaming operation.

$$
\text { AI-AFC- MENO-12736 }
$$


$$
\text { . }
$$ 
$$
\text { . }
$$ 


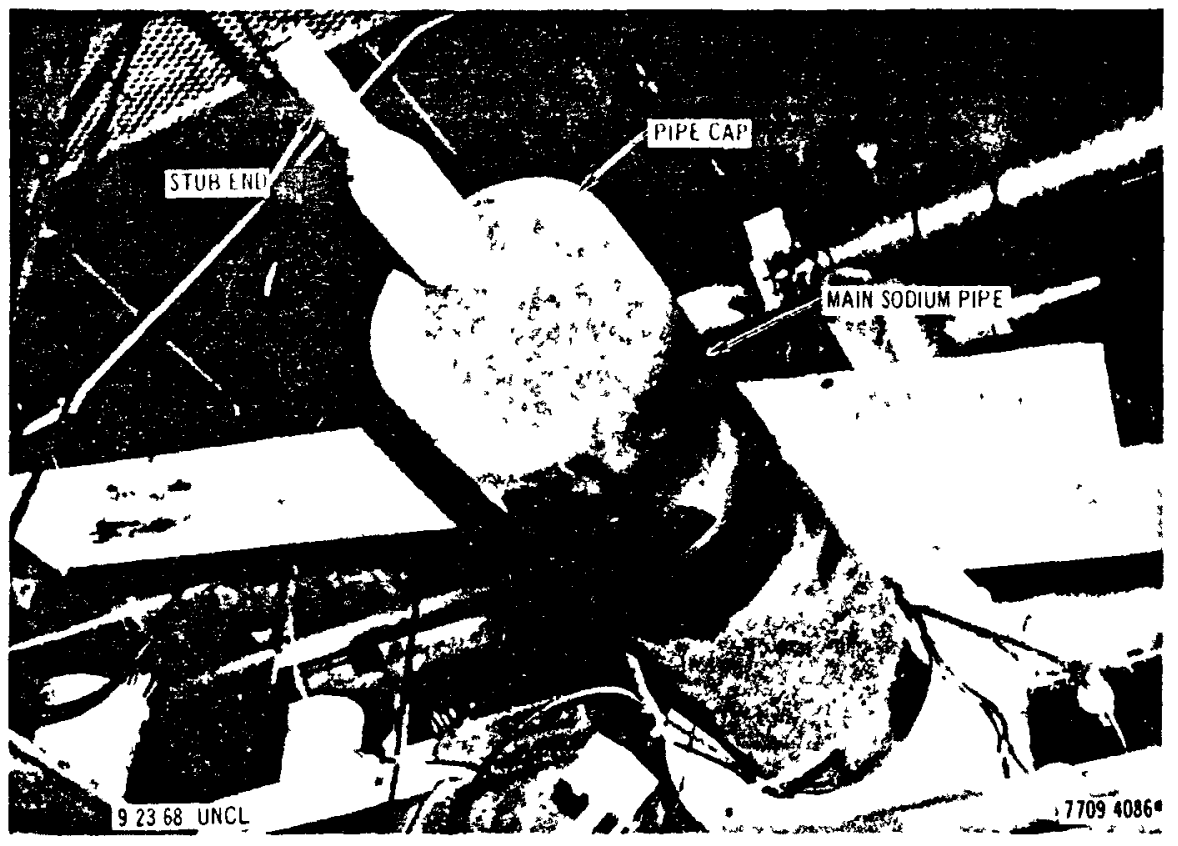

Figure 15. Main Sodium Piping in East Gallery with Pipe Caps and Stub Ends Welded Into Place

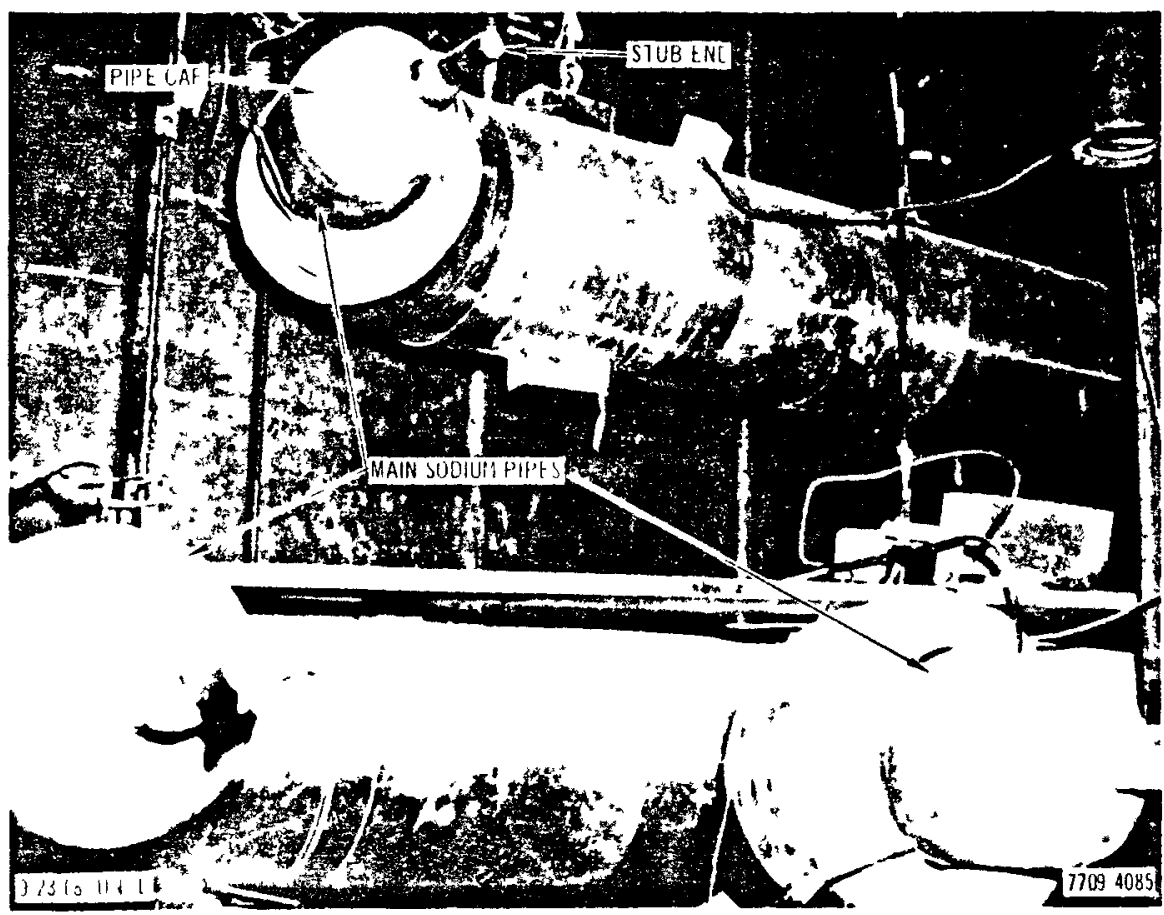

Figure 16. Main Sodium 1'iping in West Gallery with Prpe Caps and Stub Ends Welded Into Place 


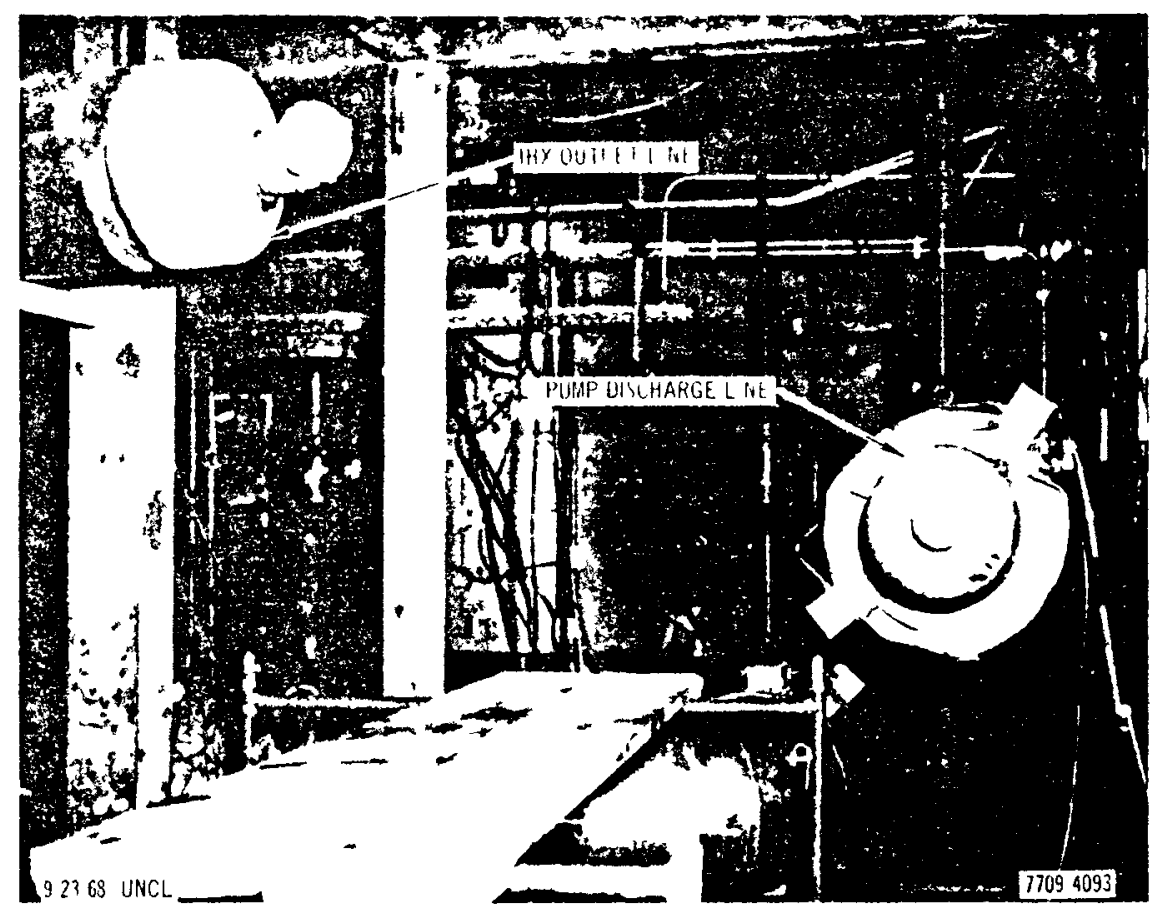

Figure 17 IIIX Outlet and Pump Discharge Lines Cut and Capped in Preparation for Installation of Bypass Loop

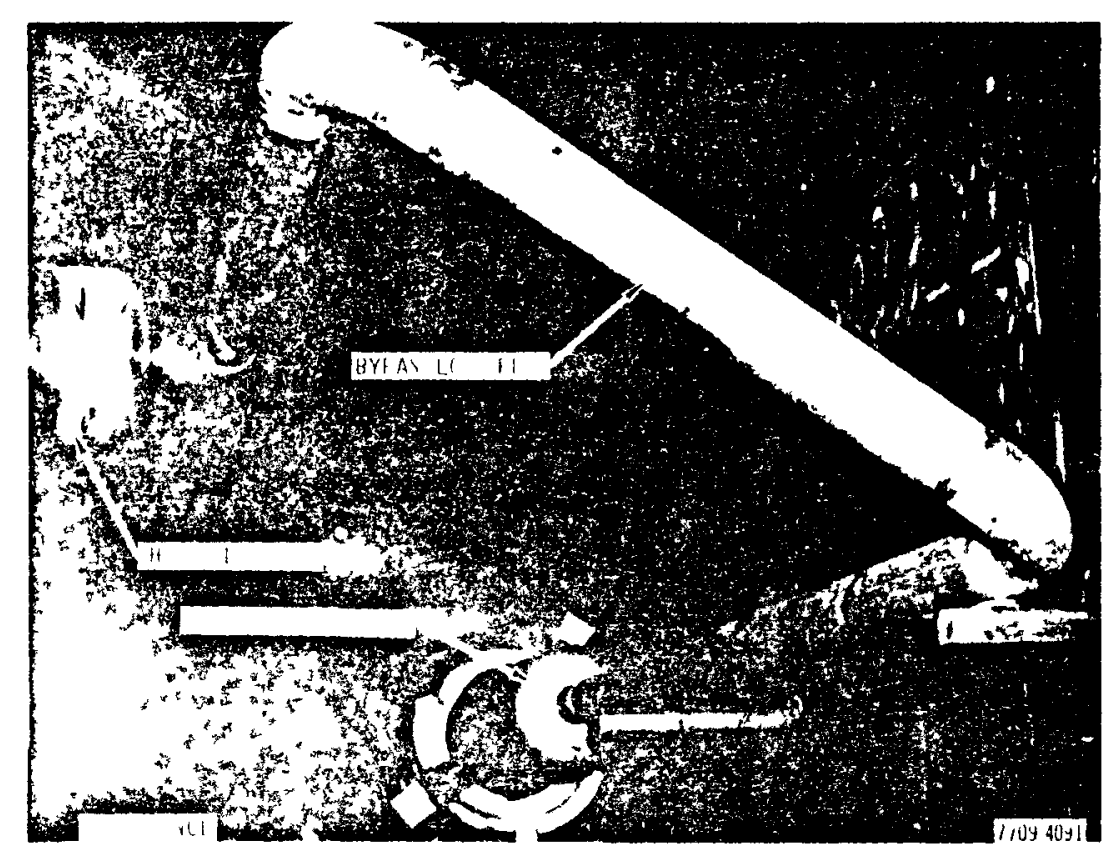

Figure 18 lijpass I,oop Piping Welded Into Place 


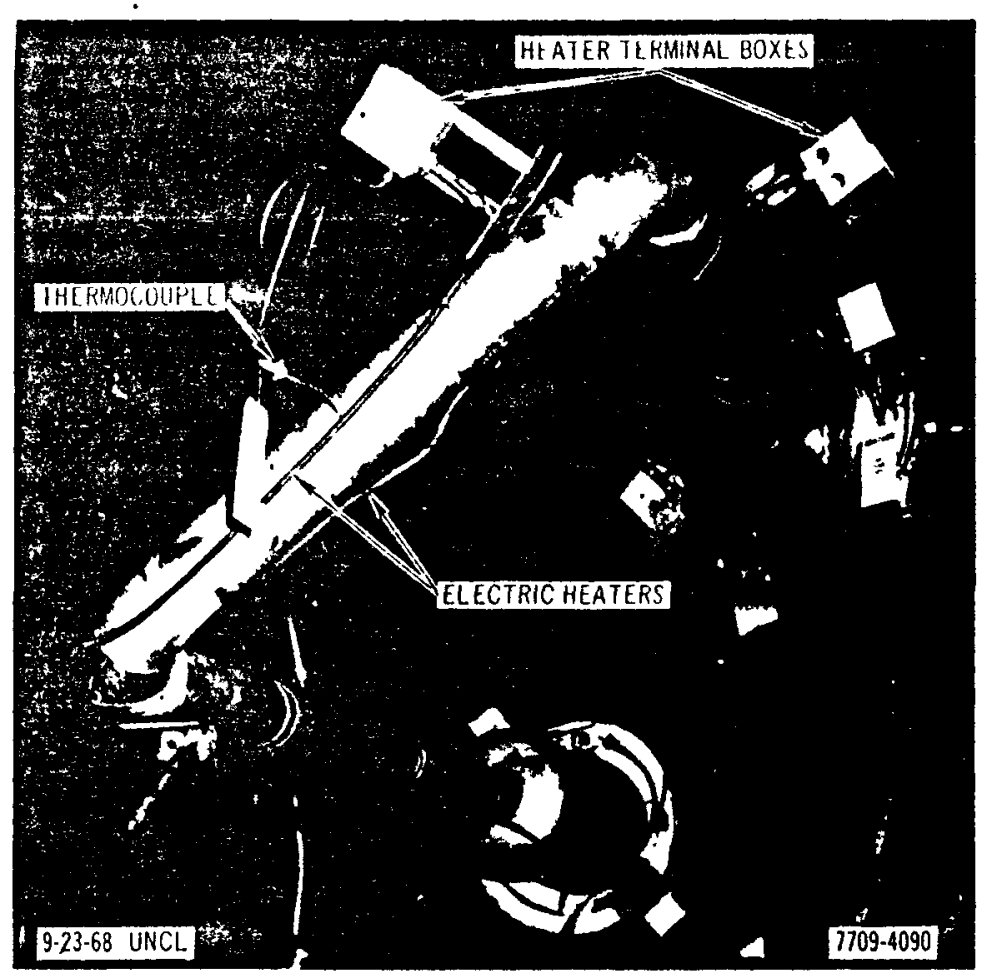

Figure 19. Bypass Loop Piping with Heaters and Thermocouple Installed

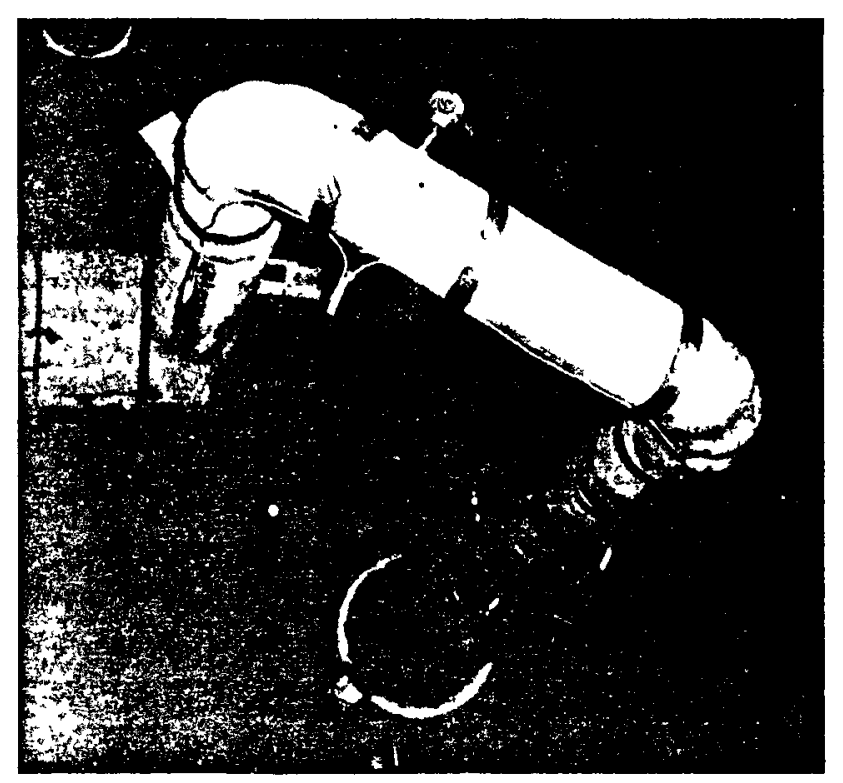

$7709-4092$

Figure 20. Completed Bypass Loop Installation

$$
\text { AI-AEC-MEMO- } 12736
$$




\section{PREPARATION OF STEAMING SYSTEM}

The steaming system was designed to supply a controlled steam-nitrogen mixture to the primary heat transfer system and to provide safe venting of the effluent gases to the plant exhaust stack. The steaming system was first connected to the reactor vessel; it was then modified and connected to the three primary heat transfer loops. For the reactor, the steam-nitrogen mixture was admitted to the connecting sodium pipes and the effluent gases were vented through the two reactor vent lines, see Figure 21 . For the primary heat trans fer loops, the steam-nitrogen mixture was admitted to the tops of the primary pump casings and vented from the pipe ends which were formerly connected to the reactor vessel, see Figure 22.

\section{Piping and Equipment}

In order to avoid excessive costs, existing plant equipment was used wherever possible. Components were selected on the basis of being "adequate" while not being specifically designed for the service for which they were used. The primary sodium service drain tank was cleaned and used as a mixing tank. One of the two spent fuel heat exchangers was used to condense steam from the effluent gases. Electrical heaters were salvaged from the sodium service systems for use on the steaming system pipelines. These heaters were connected to existing plant power supplies and control systems. Existing valves and pipe were also used where possible. A similar approach was used for the instrumentation, see Section C -2 .

Purchased components were selected and obtained from standard industrial suppliers. The basis of selection was adequacy for the short time the compo-

nents were to be in service. Another consideration in the selection of purchased components was delivery. Items requiring long delivery times were avoided. Substitutes or field expedients were used instead.

Functionally, the steaming system can be considered as being in two parts, the inlet subsystem and the effluent subsystem. The supply of steam and nitrogen was taken from existing pipelines located on the main floor, elevation $1140 \mathrm{ft} 6 \mathrm{in}$., near the reactor vessel and was piped through the inlet system to the reactor solium lines. The effluent gases were led from the reactor vent limes, through the effluent system, to the existing exhaust stack. 


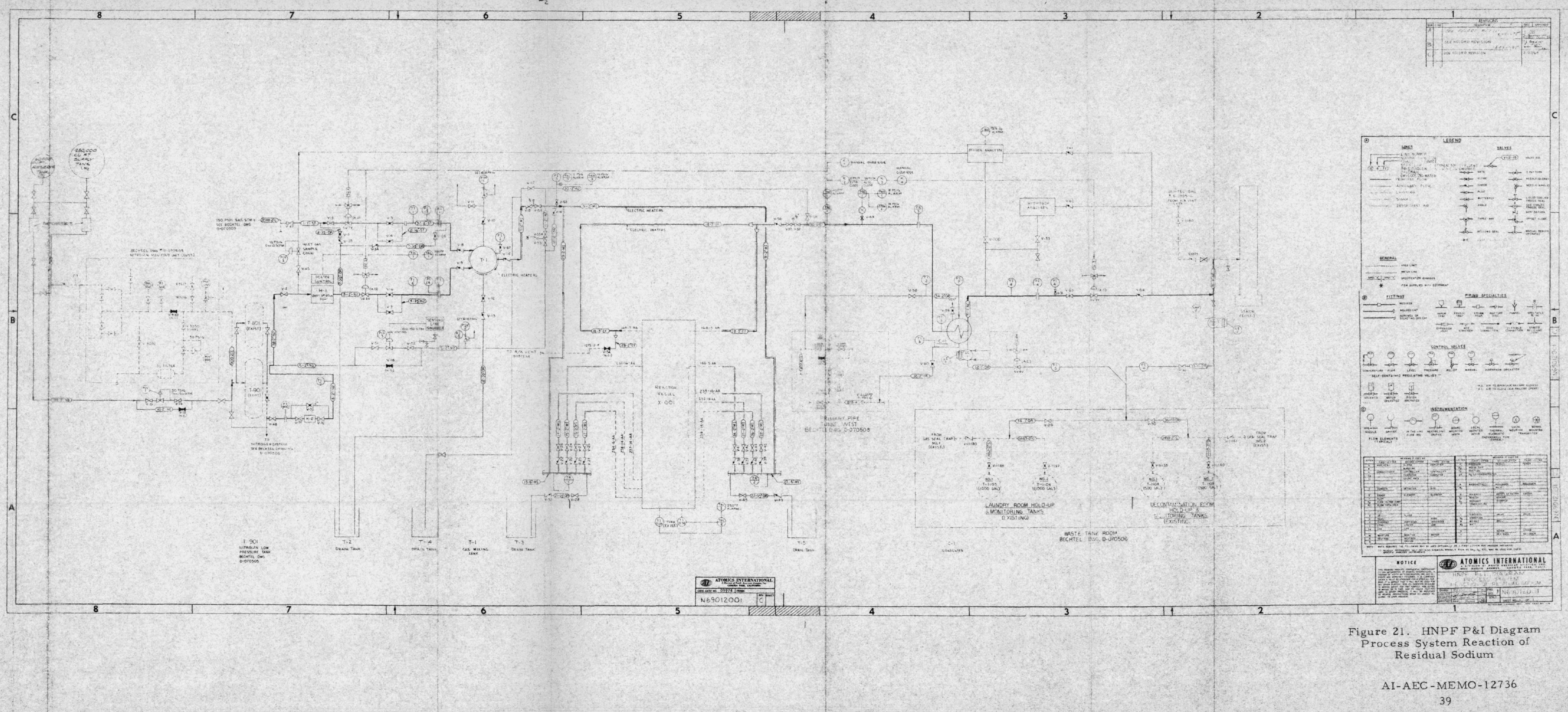


$$
\text { . }
$$ 


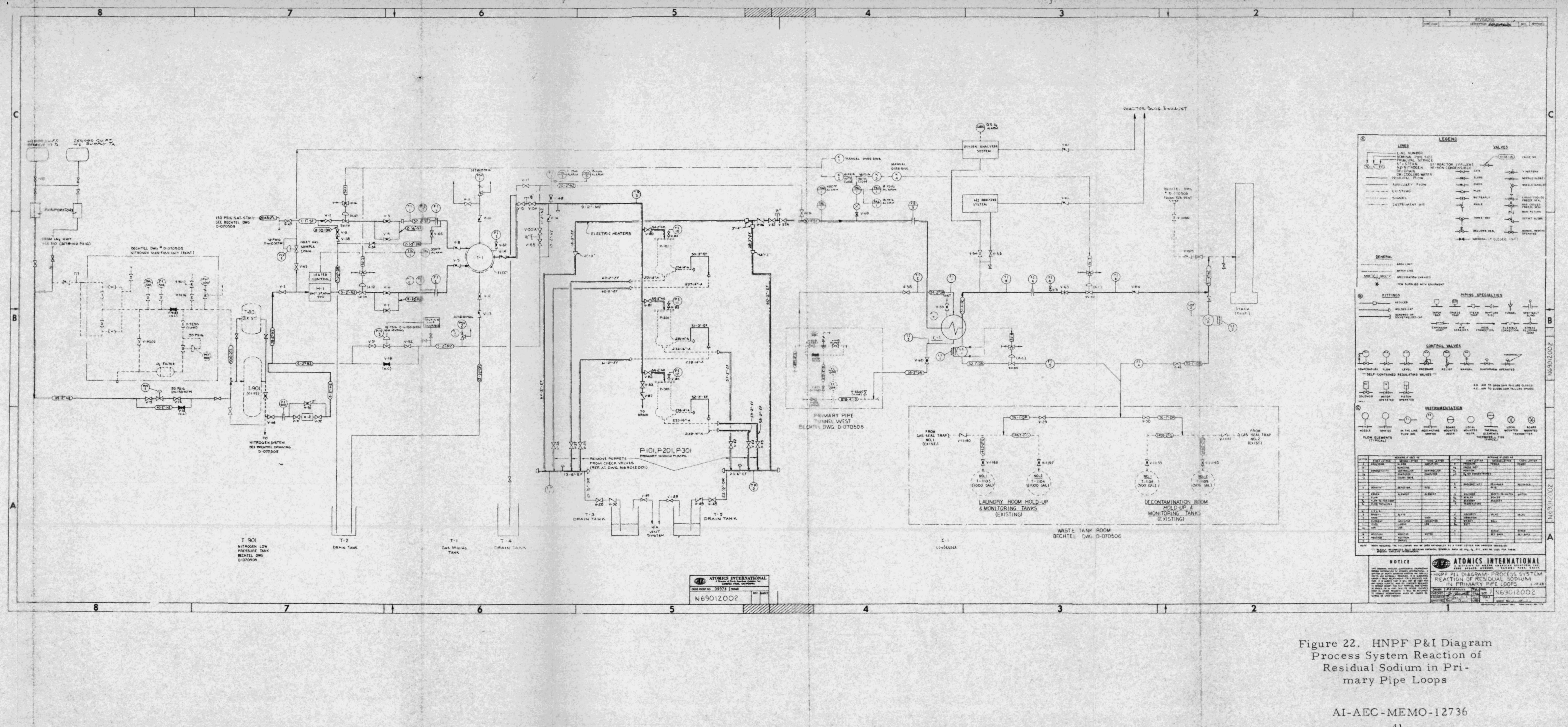


$$
\text { . }
$$ 
An overall view of the installed steaming system is shown in Figure 23. This photograph was taken while looking south and downward at the main floor in the reactor building. The reactor loading face shield is in the center foreground. The above grade portion of the inlet subsystem is on the left; the mixing tank and throttle station a re near the column just south of the reactor. From the mixing tank, piping leads to access hatch $9 \mathrm{~A}$ on the left side of the reactor and then to access hatch $9 B$ on the right side of the reactor. The above grade portion of the effluent subsystem is on the right; the effluent condenser stands in front of the office windows. From the effluent condenser, lines lead through the south wall to the exhaust stack.

\section{a. Reactor Inlet Subsystem}

The steam supply was drawn from the existing 150-psig saturated steam system, which was originally used for heating and cleaning operations. A 1 -in. pipeline led from the supply to a manual throttling station. From the throttling station, a 2 -in. pipeline led to the mixing tank. The 1 -in. steam line was equipped with an air operated valve that would close automatically on a reactor high pressure signal. The steam line contained suitable blowdown connections to permit heating and draining.

The nitrogen supply was drawn from the existing 50-psig nitrogen system which was originally used for cooling and flooding the underground vaults. The system normally had a $250,000-\mathrm{ft}^{3}$ storage tank, and evaporators capable of handling about $200 \mathrm{ft}^{3} / \mathrm{min}$. A $60,000 \mathrm{ft}^{3}$ reserve tank and additional evaporators were added to ensure an adequate nitrogen supply for the steaming operation between scheduled truck deliveries of nitrogen. A 2-in. pipeline led from the supply, through electric heaters, through the manual throttling station, and then to the mixing tank. The heaters were used to prevent condensation when the nitrogen was mixed with steam in the tank.

At the manual throttling station, both the steam and the nitrogen lines had two globe valves in parallel. One valve for each line was full size, the other was of a reduced size, see Figure 24. These valves were located near the steam and the nitrogen flowmeters to facilitate setting of the operating conditions.

From the mixing tank, the steam-nitrogen mixture was piped through electrically heated 2 -in. lines to two 6 -in. manifolds which were located below the 


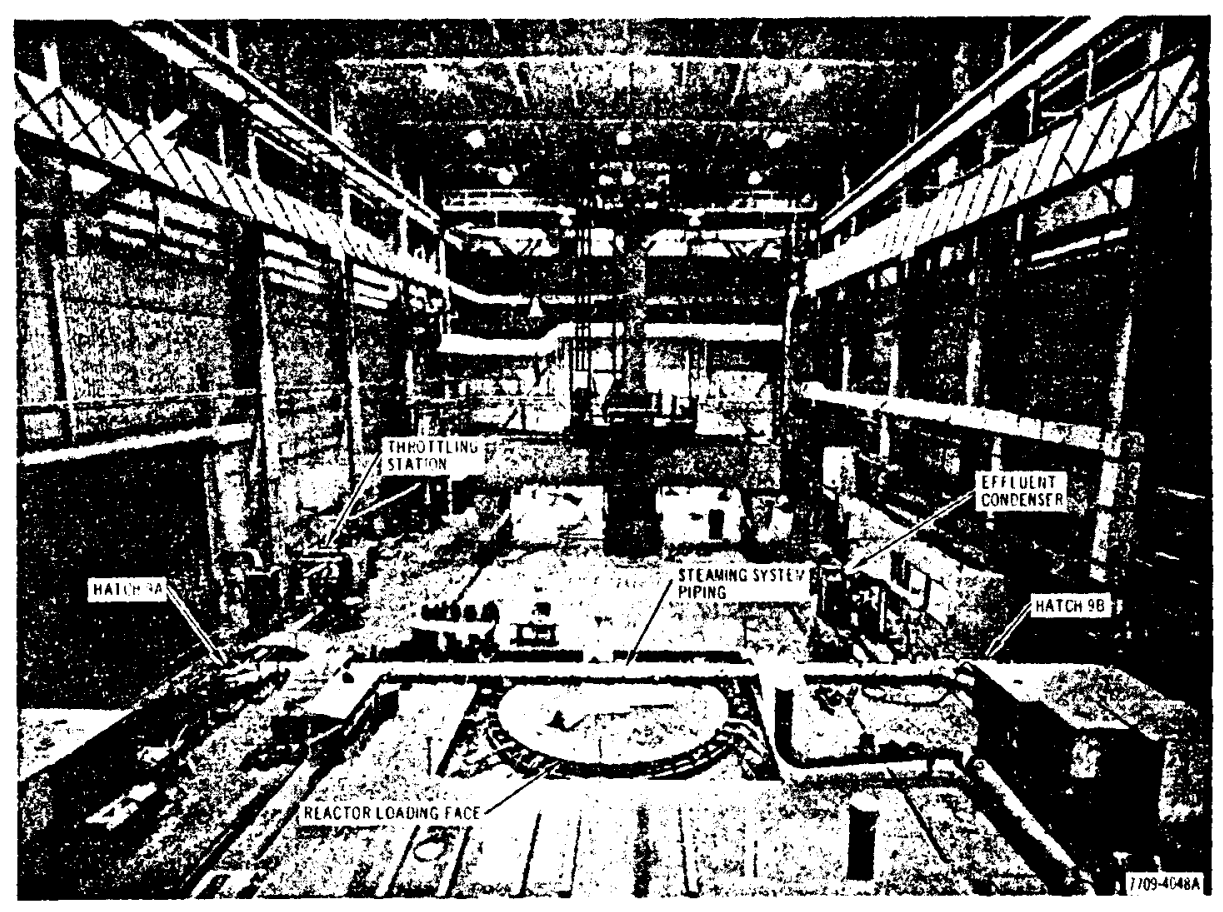

Figure 23. Overall View of Reactor Building Main Floor with Steaming System Installed

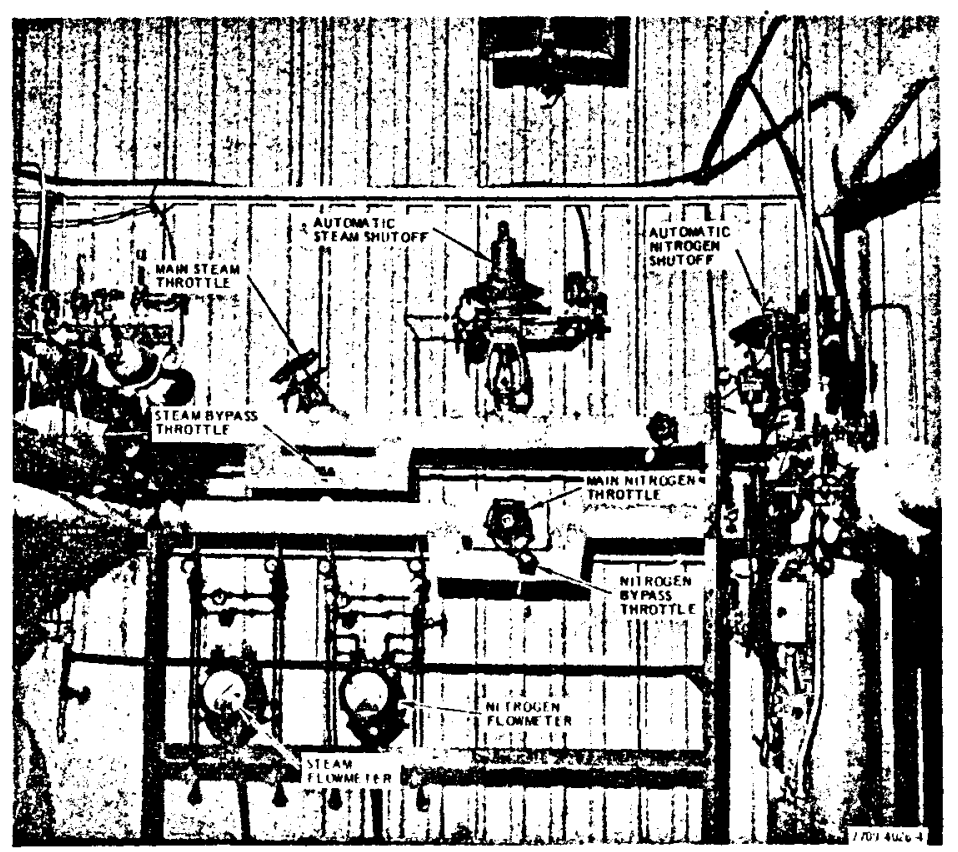

Figure 24. Manual Throttling Station 
main floor in the pipe gallery on each side of the reactor shield. These were the locations where the main sodium valves were originally installed. Access plugs in the main floor provided a convenient routing for the pipelines from the mixing tank to the inlet manifolds, see Figures 25 and 26.

A 2-in. nitrogen line bypassed the electric heaters, the throttling station, the mixing tank, and connected to the lines leading to the inlet manifolds. The bypass line was equipped with a pressure regulator to maintain a positive pressure, approximately $1 / 2$ psig minimum, in the reactor vessel. The purpose of this line was to prevent a vacuum from forming in, and drawing air into, the reactor vessel in the event of an accident. The results of such conditions could produce an explosive gas mixture.

Each 6-in. manifold had four 2-in. lines leading to the reactor sodium pipes, see Figure 27. The inlet manifolds and connecting lines were electrically heated to prevent steam condensation. A blowdown drain was provided on each manifold. A check valve and a manual shut-off valve were installed in each of the lines leading from the manifolds to the reactor sodium pipes in order to permit admission of the steam-nitrogen mixture through one sodium line at a time. The reactor sodium piping consisted of three 14 -in. lines which connected to the reactor vessel below the core, three 16-in. lines which connected to the vessel above the core, one 6-in. line which connected to the vessel in the core region, and one 3 -in. line (fill and drain) which ran through the vessel wall above the core and extended down to about 2 in. from the vessel bottom.

\section{b. Reactor Effluent Subsystem}

The conceptual design for the effluent subsystem showed the effluent gases being carried to the stack through the existing $R / A$ vent and liquid waste sys tems, see page 31 of Reference 3; however, subsequent analysis of these systems indicated that there would be too much pressure drop, especially to handle an emergency pressure surge. In order to provide adequate flow capacity without requiring high reactor pressure, the reactor vent connections we re piped directly to a condenser to remove the steam from the flow stream, and then to the stack. A manual, butterfly-type valve was used on the condenser outlet to maintain a small positive pressure on the reactor.

$$
\text { AI-AEC-MEMO-12736 }
$$




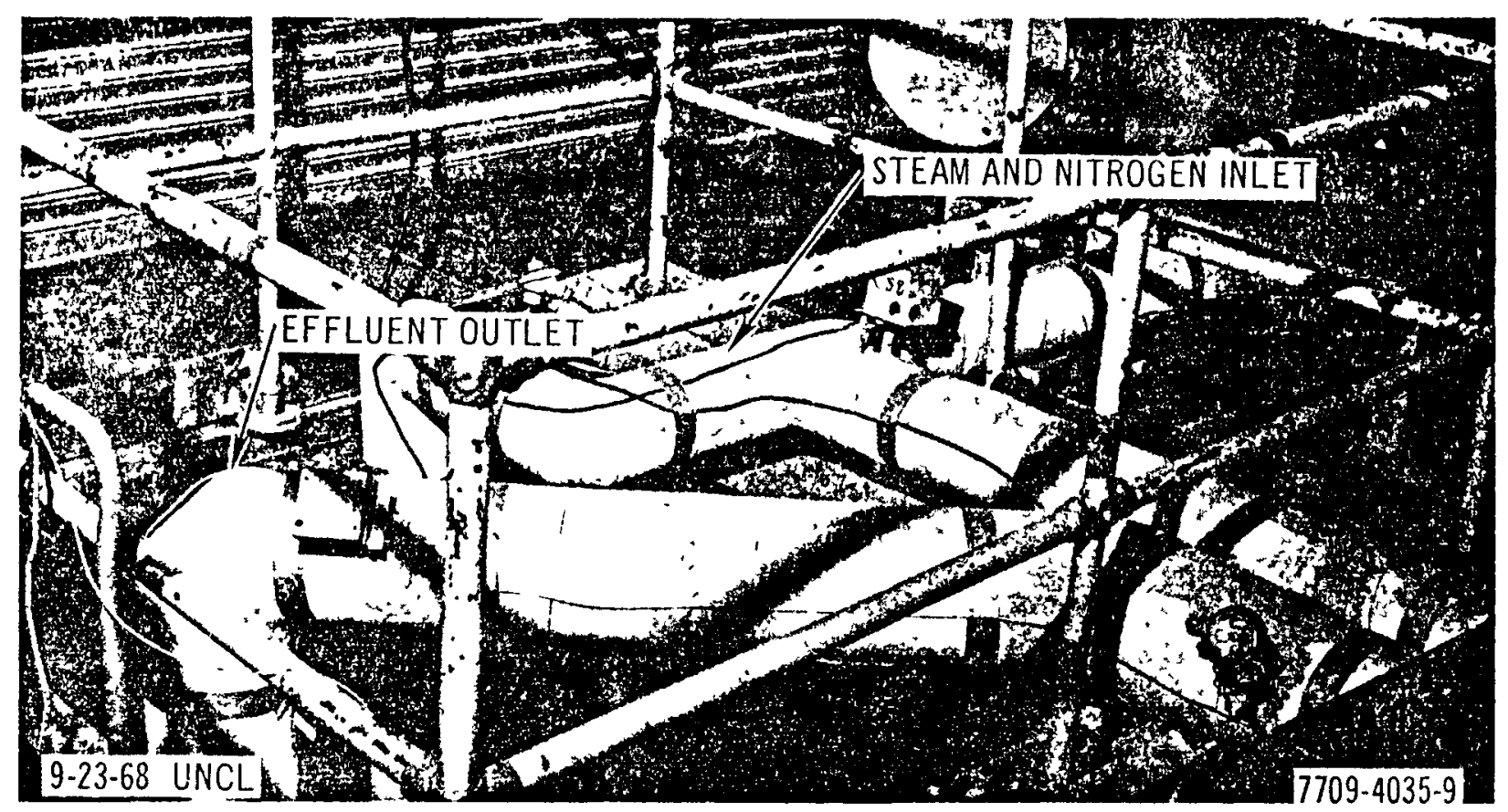

Figure 25. Hatch $9 \mathrm{~A}$ on East Side of Reactor

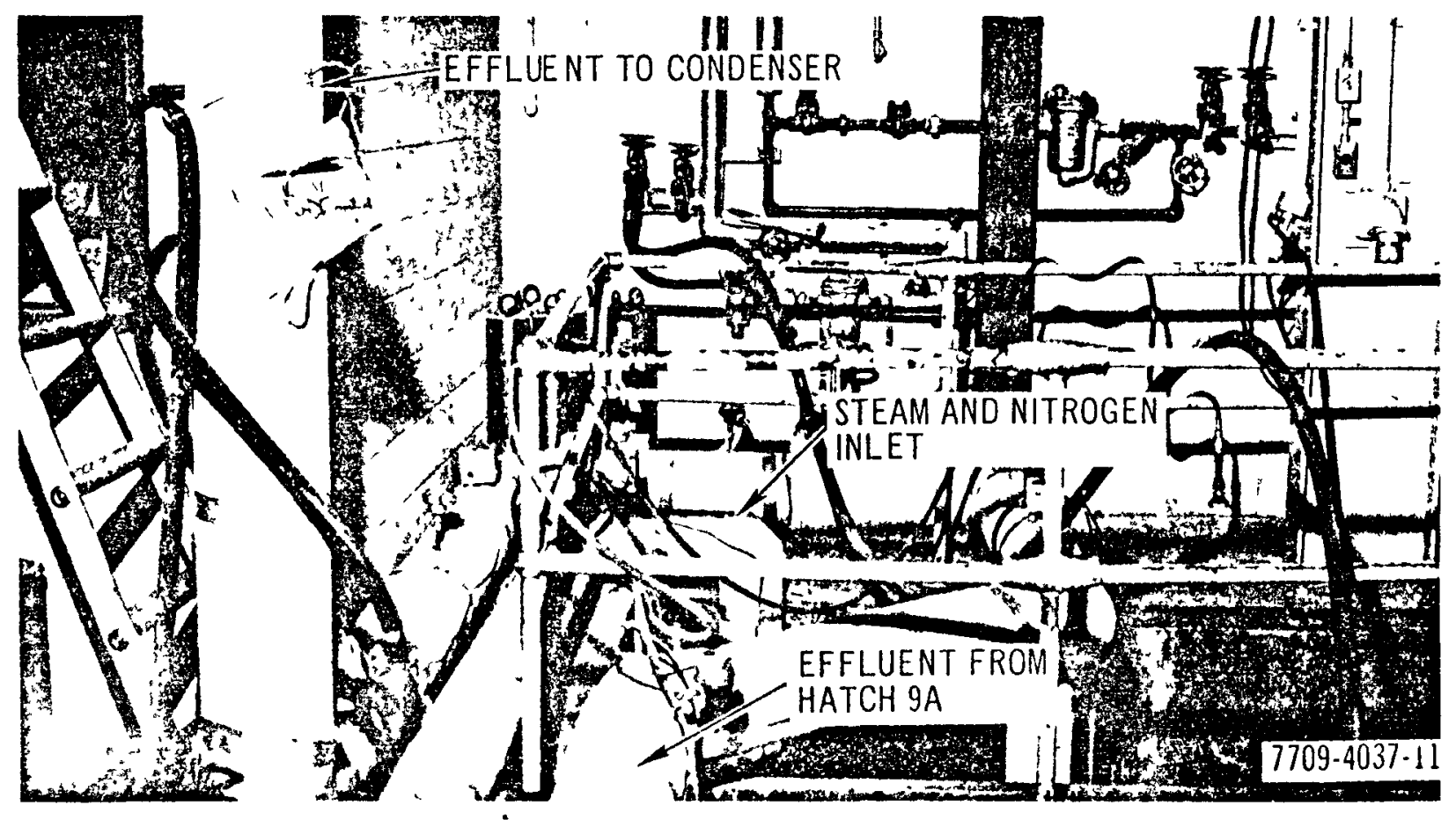

Figure 26. Hatch $9 B$ on West Side of Reactor 


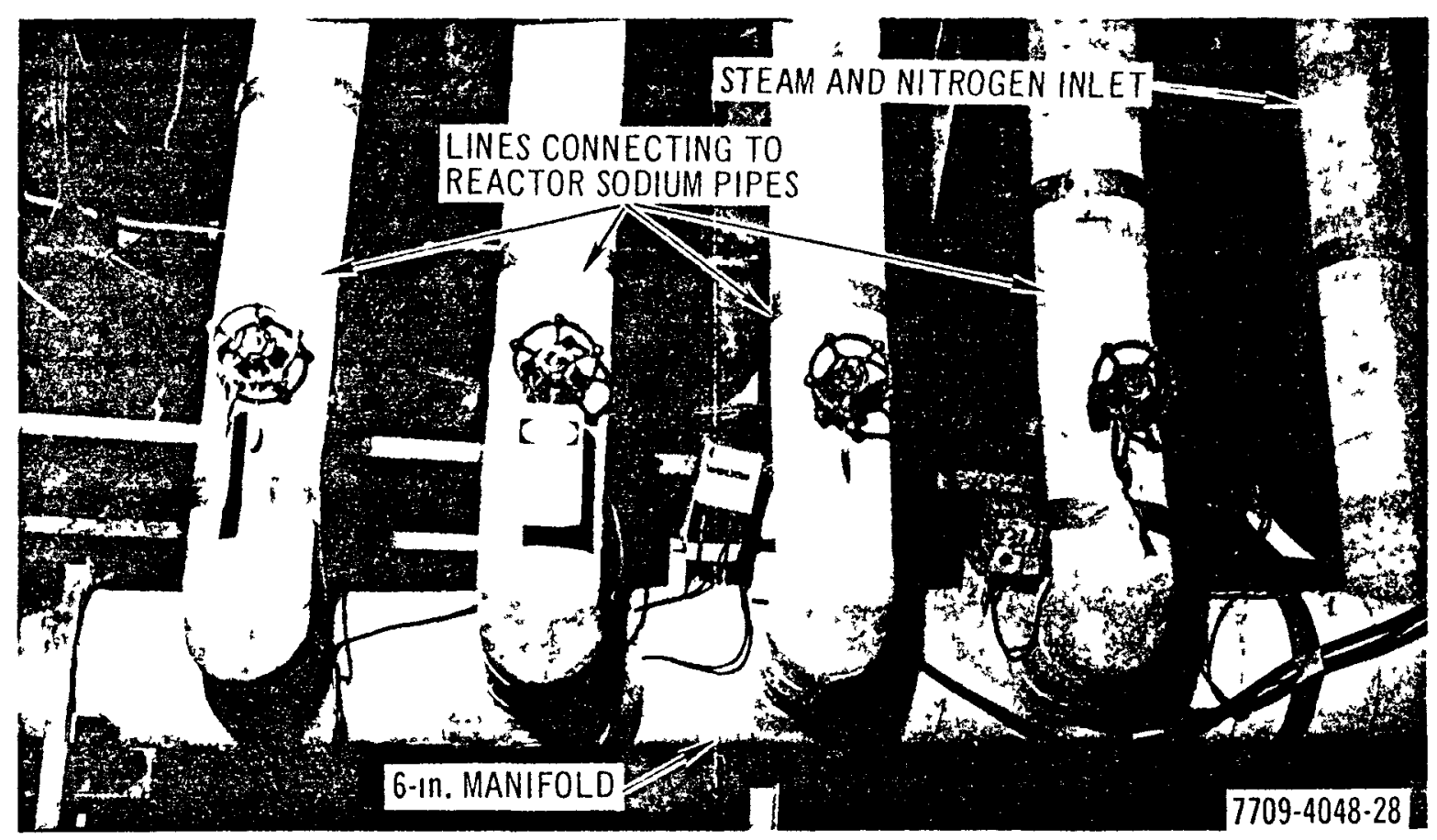

Figure 27. Manifold and Connecting Pipes in West Pipe Gallery

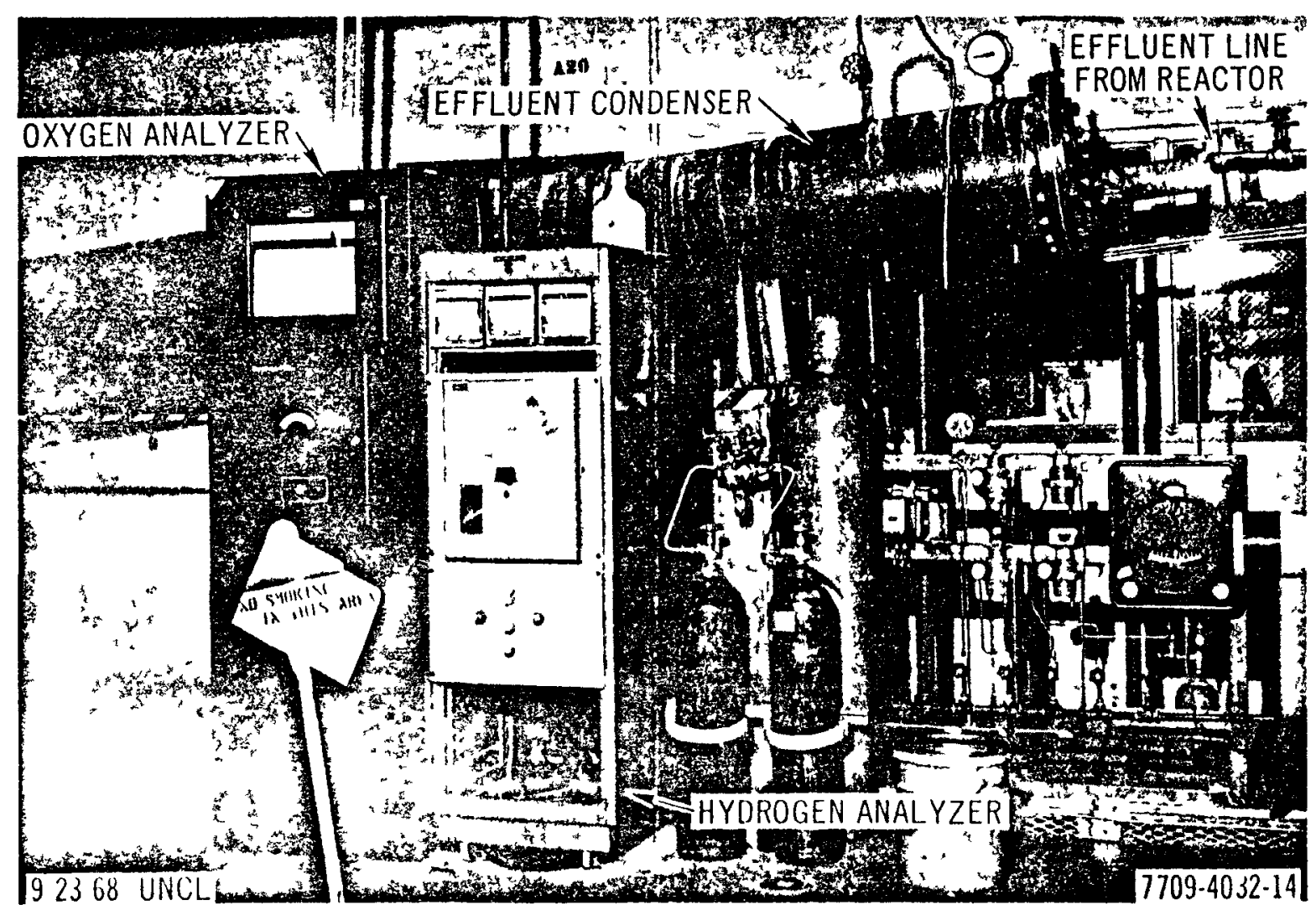

Figure 28. Effluent Condenser and Gas Analyzer Equipment 


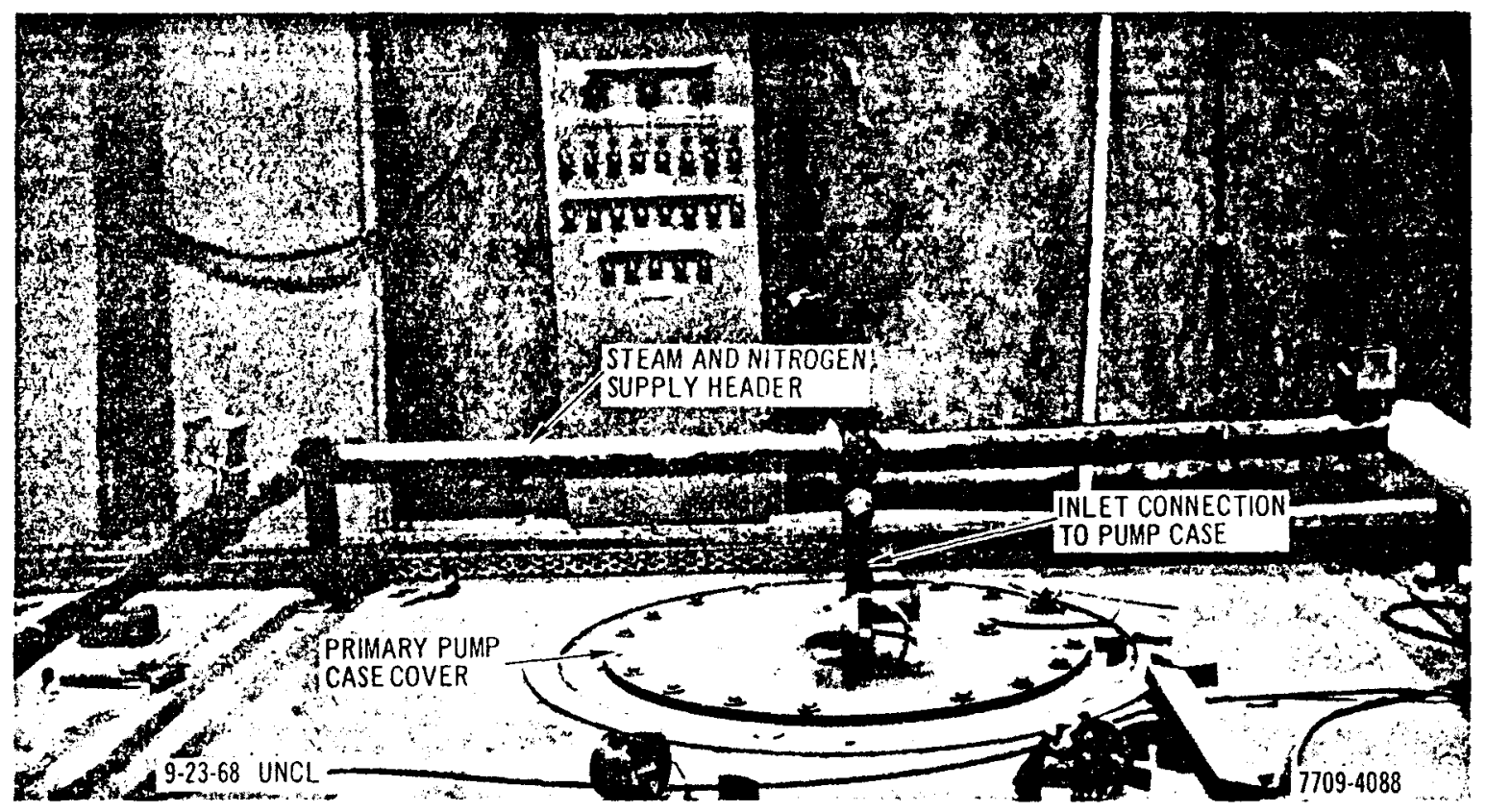

Figure 29. Typical Connection to Primary Pump Case During Installation

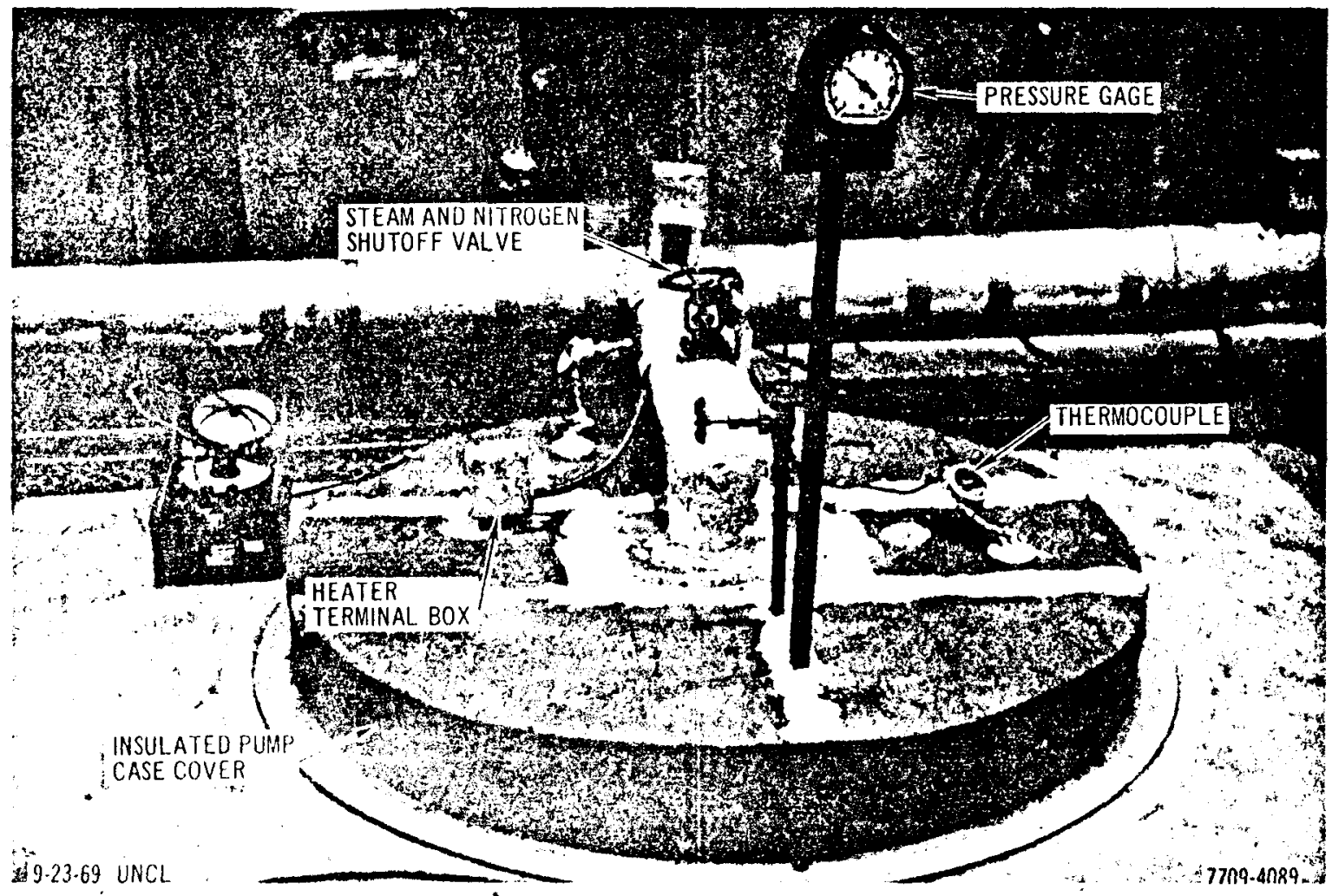

Figure 30. Typical Connection to Primary Pump Case After Installation Was Completed 
The two 3 -in. vent lines leading to the reactor vessel near the top were connected to the effluent subsystem. These lines had been used formerly as cover gas lines and were connected to the helium supply system and to the sodium service system. The vent pipes were cut and connected to 3 -in. effluent lines which led up through the access openings to a 4-in. header; the 4-in. header then ran to a condenser. All of the effluent lines to the condenser were electrically heated to prevent condensation from running back into the reactor vessel.

A shell-and-tube type heat exchanger which was originally a heat exchanger for the spent fuel storage pit was used as the effluent condenser. The heat exchanger was set up at an approximately $6^{\circ}$ angle for drainage, and the effluent gases were run through the tube side, see Figure 28. The condenser was cooled by water from the plant cooling water system. A 2-in. cooling water line was run from a below-grade nitrogen cooler, up through a hatch near the condenser, and then returned to the cooling water drain by the same route.

Wate $r$ condensed from the effluent gases was drained to the holdup and monitoring tanks for the laundry room and decontamination room. Noncondensible gases from the reactor effluent, principally nitrogen and hydrogen, were piped to the existing exhaust stack by a 4 -in. line which ran the length of the main floor and up over the filter room roof. An additional drain to the monitoring and hold-up tanks was provided at the riser which ran up over the roof. The purpose of this drain was to prevent any additional condensation from collecting in the effluent piping and causing a back-pressure on the system.

c. Heat Transfer Loop Inlet Subsystem

For steaming the primary heat transfer loops, the line formerly leading from the mixing tank to the 6-in. inlet manifolds was disconnected and run to the tops of the three primary pump casings where it was connected to the cover plates, see Figures 29 and 30 .

d. Heat Transfer Loop Outlet Subsystem

The inlet manifolds were converted to an outlet manifold by connecting them to the six sodium pipes which led to the pump suctions and the IHX outlets, see Figure 21. By this time, the IHX's had been disconnected from the sodium piping, and bypass linas were installed, see Section B. Since the flow in the lines

$$
\text { AI-A CC - MEMO- } 12736
$$


connecting the sodium pipes to the manifolds would now be reversed, the poppets were removed from the check valves in these lines. The lines which formerly led the steam nitrogen mixture to the manifolds were disconnected from the inlet subsystem and connected to the two 3 -in. effluent lines which had been connected to the reactor vents.

A comparison of the changes made to convert the steaming system from reactor steaming service to the loop steaming service can be seen by comparing Figures 21 and 22 .

In order to permit checkout of the system and to permit operators to practice system operation, a 2 -in. bypass line was installed between the inlet subsystem and the effluent subsystem. The piping and valve arrangement permitted steam and nitrogen to be run through the bypass line instead of through the reactor vessel, or the heat transfer loops. During this time, the reactor vessel, or heat transfer loops, could be maintained under slightly positive nitrogen pressure by use of the nitrogen line which bypassed the heaters, see Section V-C-1-a.

2. Instrumentation

Most of the instrumentation used to monitor the process of chemically reacting the residual sodium in the reactor vessel and three heat transfer loops (excluding the IHX's) had been salvaged from the HNPF facility or was borrowed from others. This reduced the cost of the system and eliminated additional capital investment.

A description of the use and origin of each instrument is given in Table 1. Those instruments which were part of the facility, such as the reactor vessel preheat temperature indicators and controls, are not listed.

The list of instruments, in general, is similar to the process system flow as shown in Figure 21; that is, in the following sequence.

1) Nitrogen supply to the heaters and mixing tank

2) Steam supply to the mixing tank

3) Steam-nitrogen mixture from the mixing tank to the reactor vessel

4) Effluent gas from the reactor to the condenser

5) Noncondensible gas from the conrlenser to the stack 
Table 1. Instrumentation List

\begin{tabular}{|c|c|c|c|}
\hline $\begin{array}{l}\text { Instrument } \\
\text { No. }\end{array}$ & Parameter & Description & Source \\
\hline FI-900 & $\mathrm{N}_{2}$ supply flow rat- & $\begin{array}{l}\text { Brooks, } 1-1 / 2 \text {-in., variable-area, flow-through flowmeter; } \\
0 \text { to } 150 \mathrm{scfm} \mathrm{N} \mathrm{N}_{2} \text { at } 60^{\circ} \mathrm{F} \text { and } 50 \mathrm{psig}\end{array}$ & HNPF \\
\hline TI -5 & $\mathrm{~N}_{2}$ temperature at heater outlet $(\mathrm{H}-2)$ & U.S -Gauge, well-type thermometer; 50 to $350^{\circ} \mathrm{F}$ & HNPF \\
\hline TIC -1 & $N_{2}$ heater temperature, at controller & $\begin{array}{l}\text { Indicating temperature-controller built into heater as sembly; } \\
\text { controller and protective device for } \mathrm{H}-\mathrm{l}\end{array}$ & $\mathrm{AI}^{*}$ \\
\hline$T I-6$ & $\mathrm{~N}_{2}$ temperature at heater outlet $(\mathrm{H}-1)$ & U.S. -Gauge, well-type thermometer; 50 to $350^{\circ} \mathrm{F}$ & HNPF \\
\hline$P_{1-14}$ & $\mathrm{~N}_{2}$ pressure at $\mathrm{H}-1$ outlet & Aschroft, Bourdon-tube type pressure gauge: 0 to $100 \mathrm{psig}$ & HNPF \\
\hline \multirow[t]{3}{*}{ FI-2 } & $N_{2}$ flow at mixing tank inlet $(T-1)$ & $\begin{array}{l}\text { Minn. Honeywell, Model } 292 \mathrm{D}-15 \text {, self-indicating, DP cell } \\
\text { with SS bellows: o to } 100 \text { in. water input; square root scale } \\
\text { o to } 100 \% \text { flow: formerly FI-916 at HNPF }\end{array}$ & HNPF \\
\hline & & $\begin{array}{l}2 \text {-in, } 300-1 b \text {, orifice flanges with opposing flange taps, } \\
\text { and } Z \text {-in., Sch. } 40 \text {, connecting pipes; formerly FI-605E } \\
\text { at HNPF }\end{array}$ & HNPF \\
\hline & & $\begin{array}{l}\text { 3/32-in., thick orifice plate with } 1.114-\text {-in. sharp-edged } \\
\text { concentric orifice }\end{array}$ & N.D. ${ }^{\dagger}$ \\
\hline TI- 1 & Steam temperature at mixing tank inlet & $\begin{array}{l}\text { Well-type thermometer; } 50 \text { to } 550^{\circ} \mathrm{F} \text {, Ashcroft, 4-in. dial, } \\
\text { local readout, } 2 \text {-in. deep well, } 3 / 4 \text {-in. NPT }\end{array}$ & HNPF \\
\hline PI-13 & $\begin{array}{l}\text { Steam pressure at steam line to mixing } \\
\text { tank }\end{array}$ & Aschroft, Bourdon-tube type pressure gauge; 0 to $100 \mathrm{psig}$ & HNPF \\
\hline \multirow[t]{3}{*}{$F I-1$} & Steam flow to mixing tank & $\begin{array}{l}\text { Minn Honeywell, Model } 292 \mathrm{D}-15, \text { self-indicating DP cell } \\
\text { with SS bellows; 0 to } 100 \text { in. water input; square root } \\
\text { scale } 0 \text { to } 100 \% \text { fow; formerly FI-628 at HNPF }\end{array}$ & HNPF \\
\hline & & $\begin{array}{l}\text { 2-in, , 300-1b, orifice flanges with opposing flange tops; } \\
\text { and } 2 \text {-in., Sch. } 40 \text {, connecting pipes; formerly FI-631E } \\
\text { at HNPF }\end{array}$ & \\
\hline & & $\begin{array}{l}\text { 3/32-in. thick orifice plate with } 1.260 \text {-in. sharp-edged } \\
\text { concentric orifice }\end{array}$ & N.D. ${ }^{\dagger}$ \\
\hline PI-2 & Pressure on mixing tank & $\begin{array}{l}\text { Ashcroft; SS, Bourdon-tube } 30-\mathrm{in.} \mathrm{Hg} \text {; vac } 0 \text { to } 30 \mathrm{psig} \text {, } \\
1 / 4-\text {-in., MPT Mtg; installed with condensation coil and } \\
\text { valve; both on hand at HNPF }\end{array}$ & N.A. ${ }^{\S}$ \\
\hline $\mathrm{PI}-3$ & $\begin{array}{l}\text { Pressure at reactor vessel inlet } \\
\text { manifold }\end{array}$ & $\begin{array}{l}\text { Ashcroft, SS, Bourdon-tube, } 30-\text { in. Hg, vac } 0 \text { to } 15 \text { psig, } \\
\text { l/4-in. MPT Mtg: installed with condensation coil and } \\
\text { valve and Barksdale press; SW model D2H-H18 at HNPF }\end{array}$ & N.A. $\$$ \\
\hline PI-5 & $\mathrm{N}_{2}$ mixing tank bypass pressure & Ashcroft, Brass-bellows press-gauge; 0 to 5 psig & HNPF \\
\hline TR-1 & $\begin{array}{l}\text { Steam } / \mathrm{N}_{2} \text { Inlet, east manifold, } \\
\text { temperature }\end{array}$ & $\begin{array}{l}\text { Leeds-and-Northrup, Model-H, 6-in. strip-chart recorder; } \\
\text { o to } 400^{\circ} \mathrm{F} \text { scale; IC-TC input, single-pen, 3-in. /hr chart } \\
\text { speed; formerly NLR-5; converted }\end{array}$ & HNPF \\
\hline $\mathrm{TR}-2$ & $\begin{array}{l}\text { Steam } / \mathrm{N}_{2} \text { inlet west manifold } \\
\text { temperature }\end{array}$ & $\begin{array}{l}\text { Leeds-and-Northrup, Model-H "G" strip-chart recorder, } \\
0 \text { to } 400^{\circ} \text { F; IC-TC input, single-pen, 3-in. /hr chart speed; } \\
\text { formerly NLR-3; converted }\end{array}$ & HNPF \\
\hline TRC -2 & Reactur vessel base temperature & 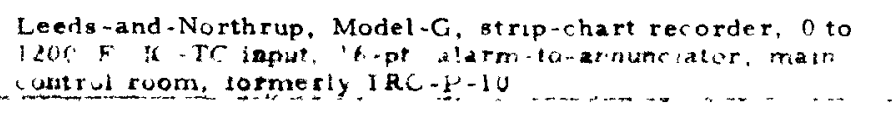 & HNPF \\
\hline TAC.1 & Reanterveste effuent iesuperature & 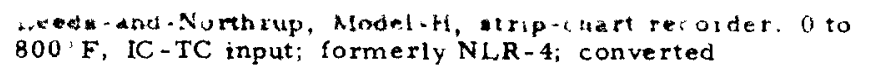 & HNPF \\
\hline \multirow[t]{3}{*}{ PRC-1 } & Reactor vessel effluent line pressure & $\begin{array}{l}\text { Mason-Neilan, Model-62100-18, 30-in. Hg vac; } 0 \text { to } 15 \text { psig; } \\
\text { input; SS-Bourdon tube, gelf-indicating with } 3 \text { to } 15 \mathrm{psi} \\
\text { transmitter; formerly PI-118T at HNPF }\end{array}$ & HNPF \\
\hline & & $\begin{array}{l}3 \text { to } 15 \text { psig, Model-5430F-E. Foxboro, 4-in. strip-chart } \\
\text { recorder, } 100 \%, 0 \text { to } 100 \% \text { linear scale, } 30-1 \mathrm{n} \text {. Hg, O to } \\
15 \text { psig; formerly TR } 204-205-206\end{array}$ & HNPF \\
\hline & & $\begin{array}{l}\text { Barksdale, D2H-H18; } 2 \text { required; from HNPF; Na throttlt } \\
\text { valve actuators }\end{array}$ & HNPF \\
\hline \multirow[t]{4}{*}{ FR - 3} & Reactor vessel effluent flow & $\begin{array}{l}\text { Minn-Honeywell, Model-292N8-G6, diff press cell; } 5 \text { to } 25 \\
\text { in. HzO input, with } 3 \text { to } 15 \text { psig transmitter; formerly } \\
\text { DPI- } 900 \mathrm{~T}\end{array}$ & HNPF \\
\hline & & $\begin{array}{l}3 \text { to } 15 \text { psig receiver, Bourdon-tube type, } 0 \text { to } 100 \% \text {, square } \\
\text { square-root marked, 3-in. scale, formerly installed on } \\
\text { main board }\end{array}$ & HNPF \\
\hline & & $\begin{array}{l}\text { 4-in., 300-lb orifice flanges with opposing flange taps; and } \\
\text { 4-in., Sch. 40, connecting pipes; formerly FI-615E at HNPF }\end{array}$ & New \\
\hline & & $\begin{array}{l}5 / 32 \text {-in. thick orifice plate with } 1.348-1 \mathrm{n} . \text { sharp-edged } \\
\text { concentric orifice }\end{array}$ & HNPF \\
\hline$T I-7$ & Reactor ve. sel effluent temperature & Ashcroft, well-type the rmometer; 50 to $300^{-} \mathrm{F}$ & HNPF \\
\hline PI-7 & Condenser inlet cooling water press & Ashcroft, Bourdon-tube type press gauge; 0 to $100 \mathrm{psi}$ & HNPF \\
\hline $\mathrm{TI}-4$ & $\begin{array}{l}\text { (Condenser outlet) effluent gas } \\
\text { temperature }\end{array}$ & $\begin{array}{l}\text { Well-type thermometer; } 30 \text { to } 180^{\circ} \mathrm{F} \text {; US gauge, } 4-1 \mathrm{n} \\
\text { dial with SS well; formerly TI-604 }\end{array}$ & HNPF \\
\hline FI-4 & (Condenser outlet) effluent gas flow & $\begin{array}{l}\text { Fisher-and-Porter, sight-flow ind with } \bmod _{1} f_{1} \text { ed flapper; } \\
\text { formerly FI-609 at HANPF }\end{array}$ & HNPF \\
\hline PI- 4 & Effluent gas line to stack pressure & $\begin{array}{l}\text { Ashcroft, SS-Bourdon-tube type, } 30 \text {-in. Hg vac to } 15 \text { psig, } \\
4 \text {-in. dial }\end{array}$ & New \\
\hline$T I-2$ & $\begin{array}{l}\text { Condenser cooling water inlet } \\
\text { temperature }\end{array}$ & $\begin{array}{l}\text { Well-type thermometer; } 30 \text { to } 180^{\circ} \mathrm{F} \text {, US gauge, 4-in. dial } \\
\text { with SS well; formerly TI-606 }\end{array}$ & HNPF \\
\hline TI-3 & $\begin{array}{l}\text { Condenser cooling water outlet } \\
\text { temperature }\end{array}$ & $\begin{array}{l}\text { Well-type the rmometer, } 30 \text { to } 180^{\circ} \mathrm{F} \text {; US gauge, 4-in. dial } \\
\text { with SS well; formerly II-617 at HNPF }\end{array}$ & HNPF \\
\hline$L I-1$ & $\begin{array}{l}\text { Condensate level (from condenser) in } \\
\text { LC }-1\end{array}$ & $\begin{array}{l}\text { Magnetrol, Model-27, float-operated level-Sw; sight-glass } \\
\text { level indicator }\end{array}$ & HNPF \\
\hline $\mathrm{LI}-2$ & $\begin{array}{l}\text { Condensate level (from line to stack) } \\
\text { in } L C-2\end{array}$ & $\begin{array}{l}\text { LC- } 2 \text { same as } L C-1 \\
\text { LI-2 same as LI-1 }\end{array}$ & HNPF \\
\hline $\begin{array}{l}\text { Alarm } \\
\text { System }\end{array}$ & & Panelarm, 10 -window unit; formerly on Board 10 at HNPF & HNPF \\
\hline FI-5 & Condensate flow from condenser & $\begin{array}{l}\text { Barton, Model-306 Flotrac; positive displacement, read out } \\
\text { in } 1 / 1000 \text { of a barrel (42 gal) }\end{array}$ & New \\
\hline FI- 6 & Condensate flow from line to stack & Same as FI-5 & New \\
\hline $\mathrm{H}_{2}$ & Hydrogen in reactor vessel effluent & $\begin{array}{l}\text { Borrowed from SRE at AI where used to monitor the wash } \\
\text { cell gas, analyzer. Complete system with pump, filter, } \\
\text { flow indicator, hydration column, and Beckman hydrogen } \\
\text { detector with a } 0 \text { to } 5 \% \text { scale }\end{array}$ & $\mathrm{AI}$ \\
\hline $\mathrm{O}_{2}$ & $\begin{array}{l}\text { Oxygen in reactor vessel effluent, } \\
\mathrm{N}_{2} \text { supply and steam }\end{array}$ & $\begin{array}{l}\text { Beckman, dual-range, } \mathrm{O}_{2} \text { analyzer, ranges } 0 \text { to } 1 \% \text { and } 0 \text { to } \\
5 \% \mathrm{O}_{2} ; \text { formerly } \mathrm{OA}-900 \text { at HNPF, converted to two inputs }\end{array}$ & HNPF \\
\hline
\end{tabular}


$$
\text { . }
$$ 
6) Condensate from the condenser to the monitoring and hold-up tanks

7) Oxygen and hydrogen gas analyzers.

Instrumentation for monitoring the steaming of the heat transfer loops was essentially the same as that used for the reactor vessel except for a few pressure indicators, one on each pump case vs one for the reactor vessel, and except for temperature indicators, the manifold temperature indicators were not used.

All instruments functioned as anticipated with no failure or erratic operation, except for the hydrogen analyzer. The hydrogen analyzer periodically recorded downward, low hydrogen concentration, spikes which could not be explained by any changes in the process. These "spikes" were of short duration and were followed by a recovery to the previous reading.

The steaming system was essentially manually controlled. Indicating instruments were monitored by the operators and control adjustments we re made when necessary or scheduled. For safety, instruments measuring critical parameters were tied to automatic actions and alarms. The alarms and automatic actions are listed in Table 2 and are shown in Figures 21 and 22.

All automatic devices were equipped with manual overrides. Automatic closure of the steam and nitrogen inlet valves (SV-IV and SV-2V) required manual resetting before the valves could be opened again. The effluent valve (SV$3 \mathrm{~V}$ ) automatically re-opens after the condition causing closure is corrected (low effluent pressure). The air operated and solenoid valves were arranged such that failure of electrical or air power would result in the inlet valves failingclosed and the effluent valve failing-open.

In order to maintain a liquid seal between the condenser drain and the holdup tanks, the controls for the automatic drain valve ( $\mathrm{SV}-4 \mathrm{~V}$ ) were set to prevent the water in the drain tank (LC-1) from being completely drained; thus, interchange of atmosphere between the radioactive waste system and the steaming system was avoided. In the event of an electrical or air power failure, the SV$4 \mathrm{~V}$ would have failed-open.

$$
\text { AI-AFC-MEMO- } 12736
$$


TABLE 2

ALARMS AND AUTOMATIC ACTIONS

\begin{tabular}{|c|c|c|c|}
\hline Condition & Sensor & $\begin{array}{l}\text { Alarm } \\
\text { Location }\end{array}$ & $\begin{array}{l}\text { Automatic } \\
\text { Action }\end{array}$ \\
\hline $\begin{array}{l}\text { 1. } \mathrm{N}_{2} \text { inlet temperature to } \\
\text { mixing tank below } \\
350^{\circ} \mathrm{F}\end{array}$ & $\mathrm{TIC} / \mathrm{l}$ & $\begin{array}{l}\text { TAL/1 Annunciator } \\
\text { on main floor }\end{array}$ & None \\
\hline $\begin{array}{l}\text { 2. Effluent outlet temper- } \\
\text { ature above } 450^{\circ} \mathrm{F}\end{array}$ & $\mathrm{TRC} / \mathrm{I}$ & $\begin{array}{l}\text { TAH/ } 1 \text { Annunciator } \\
\text { on main floor }\end{array}$ & None \\
\hline $\begin{array}{l}\text { 3. Reactor vessel tem- } \\
\text { perature below } 250^{\circ} \mathrm{F}\end{array}$ & $\begin{array}{l}\text { TI/ } 21-26 \\
\text { through } \\
\text { TI/ } 21-30\end{array}$ & $\begin{array}{l}\text { TAL/ } 2 \text { Annunciator } \\
\text { in reactor control } \\
\text { room }\end{array}$ & None \\
\hline $\begin{array}{l}\text { 4. Steam }-\mathrm{N}_{2} \text { mixture } \\
\text { pressure to reactor } \\
\text { below } 1 / 4 \text { psig }\end{array}$ & $\mathrm{PI} / 3$ & $\begin{array}{l}\text { PAL } / 3 \text { Annunciator } \\
\text { on main floor }\end{array}$ & None \\
\hline $\begin{array}{l}\text { 5. Steam- } \mathrm{N}_{2} \text { mixture } \\
\text { pressure to reactor } \\
\text { above } 10 \text { psig }\end{array}$ & $\mathrm{PI} / 3$ & $\begin{array}{l}\mathrm{PAH} / 3 \text { Annunciator } \\
\text { on main floor }\end{array}$ & None \\
\hline $\begin{array}{l}\text { 6. Effluent outlet pres- } \\
\text { sure below } 1 / 4 \text { psig }\end{array}$ & $\mathrm{PRC} / \mathrm{l}$ & $\begin{array}{l}\text { PAL/l Annunciator } \\
\text { on main floor }\end{array}$ & $\begin{array}{l}\text { Valve SV }-3 V \text { on } \\
\text { effluent line to } \\
\text { stack closes }\end{array}$ \\
\hline $\begin{array}{l}\text { 7. Effluent outlet pres- } \\
\text { sure above } 8 \text { psig }\end{array}$ & $\mathrm{PRC} / 1$ & $\begin{array}{l}\mathrm{PAH} / \mathrm{l} \text { Annunciator } \\
\text { on main floor }\end{array}$ & None \\
\hline $\begin{array}{l}\text { 8. Effluent outlet pres- } \\
\text { sure above } 10 \text { psig }\end{array}$ & $\mathrm{PRC} / \mathrm{l}$ & $\begin{array}{l}\text { Indicator light on } \\
\text { relay K2 }\end{array}$ & $\begin{array}{l}\text { Valves } S V-1 \mathrm{~V} \text { and } \\
S V-2 V \text { on steam } \\
\text { and } \mathrm{N}_{2} \text { lines to } \\
\text { mixing tank close }\end{array}$ \\
\hline $\begin{array}{l}\text { 9. Water collecting in } \\
\text { effluent line to stack }\end{array}$ & $\mathrm{LC} / 2$ & $\begin{array}{l}\text { LAH } / 2 \text { Annunciator } \\
\text { on main floor }\end{array}$ & None \\
\hline
\end{tabular}

D. PREPARATION OF EXISTING FACILITIES

During removal of the primary and secondary sodium storage tanks, it was necessary to remove the helium system control board and the helium supply manifold system. Since helium was no longer required as a cover gas, the cover gas system was pressurized from the nitrogen supply system by connecting the two low pressure tanks in parallel. The low pressure nitrogen tank $(T-901)$ and the low pressure helium tank (T-801) were adjacent to each other 
and both operated at $50 \mathrm{psig.} \mathrm{Nitrogen} \mathrm{was} \mathrm{normally} \mathrm{supplied} \mathrm{to} \mathrm{the} \mathrm{low} \mathrm{pres-}$ sure nitrogen tank from an outdoor liquid nitrogen tank capable of storing $250,000 \mathrm{scf}$ through an evaporator and a pressure control system.

It was originally planned to connect an auxiliary 45,000 scf supply of bottled nitrogen to the low pressure tanks for emergency use, in the event that the normal supply was exhausted or the evaporators frozen. Further investigation revealed that bottled nitrogen in this quantity would be awkward to handle, would require many bottles, and would necessitate installation of a manifold. Instead, an auxiliary $60,000 \mathrm{scf}$ liquid nitrogen tank was installed adjacent to the 250,000 scf tank and an auxiliary set of evaporators were installed to increase the total evaporator capacity. The system was piped so that either or both tanks could supply nitrogen through both sets of evaporators.

The existing nitrogen pressure control system between the evaporators and the low pressure tanks was constructed with 3/4-in. pipe and could not pass the required $200 \mathrm{scfm}$ for the steaming operation. In order to increase the flow capacity between the evaporators and low pressure tanks, a 2 -in. bypass line with control valves was installed in parallel with the existing system.

\section{E. STEAMING OPERATION}

Prior to admitting steam to the reactor vessel, the operational status of the steaming system was thoroughly checked by using flow through the reactor bypass line. During this time, the reactor vessel was kept under a slightly positive pressure by the pressure regulator in the nitrogen line; this bypassed the heaters and throttling station. In addition to checking out the manual controls, the set points for alarms and automatic actions we re also checked.

After making the necessary adjustments and correcting minor malfunctions in the steaming system, the reactor vessel was pressurized to $10 \mathrm{psig}$ with nitrogen to check the hold-down devices on the fuel plugs. When all equipment functioned properly, the reactor was designated as ready to be steamed.

\section{Stcaming Reactor Vessel}

The reactor steaming operation closely followed the procedures outlined in the AI Activity Specification No. 5 (Appendix B) and in the Retirement Detailed Procedure 5-5 (Appendix $C$ ). Steam and nitrogen flow rates entering the reactor

$$
\text { AI - AEC - MEMO- } 12736
$$


vessel were set to the "approximate" values given in the detailed procedure. Precise settings werc not attempted since the flow rates as originally specified in the activity specification were based on approximate, rather than precise requirements. Occasional on the spot calculations were made to ensure that the steam-nitrogen mixture ratio and the total flow rate were in the correct range. All readings were logged for future analysis.

During operation, it was necessary to make some minor changes in flow rates and valve set positions in order to keep the reaction within desirable limits; i.e., steam flow rates were adjusted to keep the effluent hydrogen concentration under $5 \%$ which was the upper limit of the hydrogen analyzer readout.

As expected, the reaction proceeded in a well-controlled manner. No temperature or pressure surges were noted. At no time did the indicated oxygen content of the inlet nitrogen or effluent gases exceed $1 \%$. The hydrogen meter showed some signs of erratic operation, as described in Section V-C-2, but the erratic readings were easily identifiable on the meter strip chart (see Figure 31). Generally, the hydrogen concentration in the effluent gas proved to be a good indicator of reaction rate and was fairly responsive to changes in inlet steam concentration.

When similar large scale steaming operations are to be performed, it is suggested that the efflucnt hydrogen concentration be considered as one of the prime indicators for control purposes.

One unexpected event occurred during the reactor steaming operation. After about $65 \mathrm{hr}$ of steaming, the Cerrobend seal (a low melting temperature seal between the loading face shicld and the reactor vessell melted in a region about $10 \mathrm{ft}$ long. Cerrobend is a bismuth-lead-tin-cadmium alloy, produced by the Cerro de Pasco Co., which melts at about $158^{\circ} \mathrm{F}$. It was used in a manometer type seal around the periphery of the loading face shield. During refucling operations, it could be melted, permitting the loading face shield to be turned while maintaining a seal on the reactor vessel. The seal region was normally cooled during reactor operation by the loading face cooling system.

Approximately $1-1 / 2$ in. of Cerrobend material was blown out of the seal in a local spot. In orter to refreeze the seal, service air hoses were set up to direet in air stroum across the Corrobend surface and through the loading face 


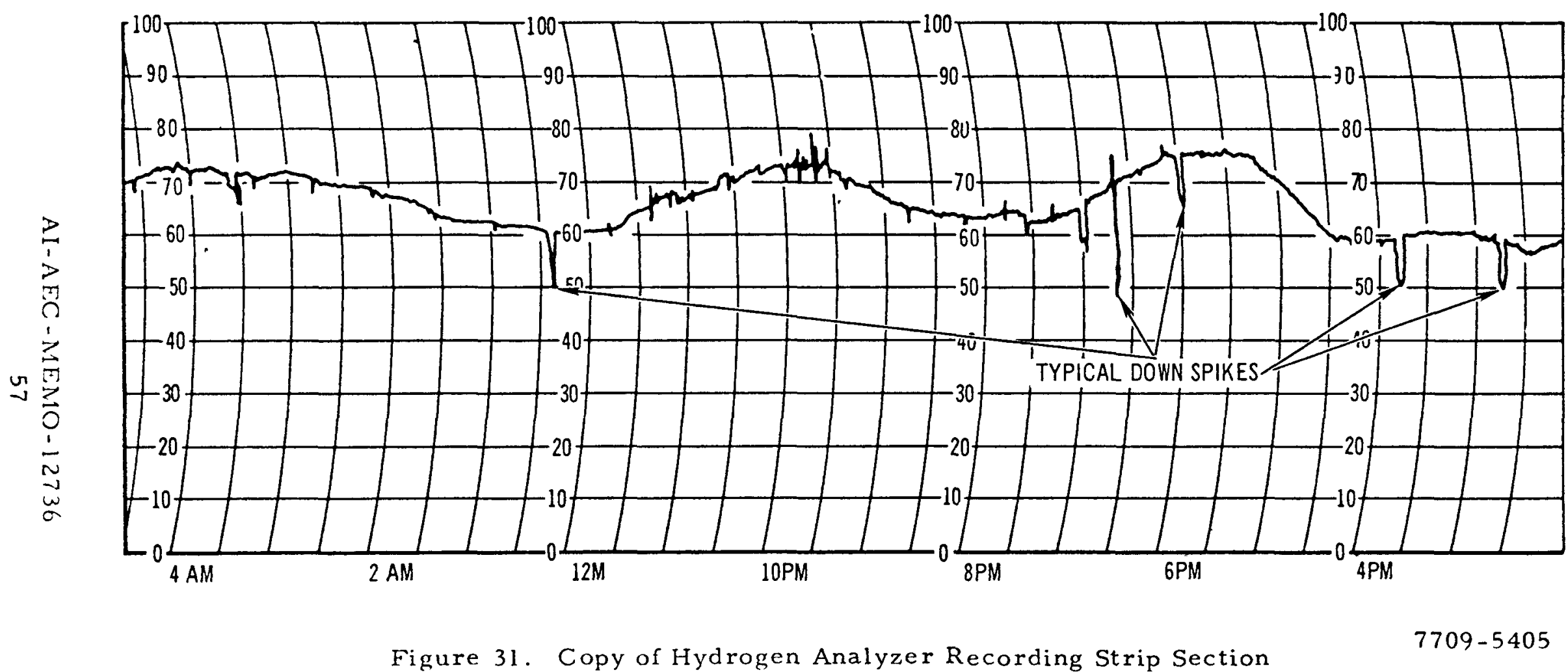


cooling coils. Another diagonally opposite melt occurred within a few hours. Service air was also used to cool this region. With the use of service air for cooling, it was possible to keep all the seal in a frozen or plastic state and to continue steaming; steam flow had been secured when the initial melt occurred.

The two melt regions had occurred approximately above the two reactor vent lines. It was postulated that the flow of hot steam and nitrogen through the vent lines had transferred sufficient heat to melt the seal to the vessel walls, by convection, and then to the seal region, by conduction. The steam-nitrogen mixture temperature flowing through these lines was about 300 to $350^{\circ} \mathrm{F}$.

Steaming of the reactor vessel was continued for a total of about $82 \mathrm{hr}$, including $6 \mathrm{hr}$ at the end, with zero hydrogen concentration indicated; after steaming, two sample cups were pulled from the reactor vessel. Both samples were in a "reddish-brown" liquid state. A small solid particle about the size of a match head was found at the bottom of one sample cup. This particle was put into water (to see if it was sodium) but no reaction occurred. It was then concluded that all residual sodium in the reactor vessel had been reacted with the steam and that drying operations could begin.

The drying operation was accomplished by setting the reactor preheaters up to $450^{\circ} \mathrm{F}$ and purging the reactor vessel with hot $\left(\sim 400^{\circ} \mathrm{F}\right)$ nitrogen at a flow rate of $80 \mathrm{cfm}$. The drying operation continued for about $38 \mathrm{hr}$ after which the remainde $r$ of the sodium samples were pulled. Inspection of the samples indicated that the sodium hydroxide had solidified. The reactor vessel was then slowly cooled and all systems were secured except for one nitrogen line which maintained a low ( $1 / 2$ psig) positive pressure in the reactor vessel.

\section{Steaming Heat Transfer Loops}

After completion of the reactor steaming operation, the steaming system was morlified, as shown in Figure 22, for steaming the heat transfer loops. The procedures for this phase of the steaming operation were given in the Retirement Detailed Procedure 5-6, which was also written in conformance with Activity Specification No. 5, Appendix D.

The primary heat transfer loops were steamed one at a time with the steamnit rogrn mixture entering each loop through the cover plate at the top of the pump case and effluent gases leaving through the lines leading to the pump 
section and from the IHX, now isolated and bypassed. The steaming operation was essentially the same as that used for the reactor vessel except for the flow rates, which were reduced.

Response of the heat transfer loops to control valve adjustments was much more rapid and erratic than was that of the reactor vessel. The difference was probably due to differences in size and configuration of the two systems. The reactor vessel was essentially a huge pot with the major mass of sodium being on the bottom where steam was first admitted. Effluent gases left the vent lines which were near the top. There was adequate space (and time) for diffusion of hydrogen with the effluent steam and nitrogen. Also, all connecting piping and internal components drained to the bottom of the reactor vessel. The system had sufficient inertia to mask any rapid changes in temperature, pressure, or effluent hydrogen concentrations which might have occurred due to local reactionrate transients.

On the other hand, the heat transfer loops were essentially pipe runs, each with significantly less volume (a few hundred cubic feet vs $7000 \mathrm{ft}^{3}$ ) and less system inertia. All components drained to a point near the vent connections where local perturbations in reaction rate could produce significant changes in the effluent hydrogen indicator. The smaller volume of the heat transfer loops would also make pressure increases due to increased temperature and hydrogen generation rates more evident than in the reactor vessel. During the loop steaming operation, the indicated hydrogen concentration in the effluent gas was subject to sharp increases, sometimes exceeding the instrument range, $5 \%$. The hydrogen concentration could be rapidly reduced by reducing or shutting off the steam supply while maintaining the nitrogen flow rate. Observation of the loop pressure, by use of a pressure gage on the pump case cover, and by monitoring the flow leaving the condenser by means of a glass-sided flow indicator, showed that sharp increases in hydrogen concentration we re accompanied by pressure increases and white smoke in the condenser exit line. Pressure increases of approximately 2 psi were observed, but at no time did the loop pressure exceed, or approach, 10 psig which was set as an operating limit. The smoke observed in the "see-through" flowmeter subsided when the hydrogen concentration dropped.

AI-AEC-MEMO- 12736 
Despite the fluctuating conditions, steaming of the primary loop was continued until each loop had been steamed, including $6 \mathrm{hr}$ at a zero hydrogen concentration. After steaming of the three loops was completed, the loops were dried with the preheaters and hot nitrogen, and allowed to cool. A 4-in. diameter inspection hole was then cut into the pipe wall near the ends of the loop piping; each end of the loop piping was a low point in the sodium piping system. Inspection of the piping interiors showed that the residual sodium hydroxide had solidified into a crystalline mass with no trace of moisture evident. Samples of the residue were taken where an adequate amount remained in the pipe. These samples were subsequently mixed with water and tested for residual sodium. No traces of free sodium were found.

\section{F. ANALYSIS OF RESULTS FROM REACTOR STEAMING OPERATION \\ 1. Calculated Results}

Inspection of the chemical equations for the reaction between sodium and steam (or water) indicates that two methods might have been used for determining the amount of sodium reacted in the reactor vessel. The basic reaction equation is

$$
2 \mathrm{H}_{2} \mathrm{O}+2 \mathrm{Na} \rightarrow 2 \mathrm{NaOH}+\mathrm{H}_{2}
$$

This equation may be expanded to

$$
x \mathrm{~N}_{2}+\mathrm{yH}_{2} \mathrm{O}+\mathrm{z} \mathrm{Na} \rightarrow(\mathrm{y}-\mathrm{z}) \mathrm{H}_{2} \mathrm{O}+\mathrm{z} \mathrm{NaOH}+(\mathrm{z} / 2) \mathrm{H}_{2} \uparrow+\mathrm{xN}_{2}
$$

where:

$$
\begin{aligned}
\mathbf{x}= & \text { amount of nitrogen entering and leaving the process (nitrogen } \\
& \text { served only as an inert diluent for the steam), } \\
y= & \text { amount of steam entering the process, } \\
z= & \text { amount of sodium reacted and sodium hydroxide generated, } \\
(y-z)= & \text { amount of steam leaving the process (due to process inefficiencies), } \\
& \text { and } \\
(\mathrm{z} / 2)= & \text { amount of hydrogen generated. }
\end{aligned}
$$


During the process, measurements were made of $x, y,(y-z)$, and the quantity $\alpha=(z / 2) /(z+2)$ which is the hydrogen concentration at the condenser outlet. From the process equation, it would appear possible to calculate the amount of sodium reacted by using the steam and nitrogen inlets data plus the outlet hydrogen concentration:

$$
z=2\left[\frac{\alpha}{\alpha-1}\right] \times
$$

Or, one could use the difference in amounts of steam entering and leaving the process:

$$
z=y-(y-z)
$$

After reviewing the process and flow diagrams, and observing the process in operation, it was decided that the second method would give the least meaningful results for the following reasons.

1) The calculation would involve a small difference between two large numbers, making it subject to large errors due to small measurement errors.

2) A continuous blowdown was maintained on the steam line, after the meter orifice. This results in a portion of the steam inlet flow never reaching the reactor vessel:

3) All of the steam not used in the reaction did not pass through the condensate drain flowmeter. Some of the steam remained condensed in the sodium hydroxide. Even after drying, each sodium hydroxide molecule holds one or more molecules of water of crystallization.

Calculation of the amount of sodium reacted was the refore based on the effluent hydrogen concentration and the amount of nitrogen entering the system. Since the reaction process proceeded in a fairly steady manner and instrument readings we re recorded at frequent intervals ( $1 / 2$ to $1 \mathrm{hr}$ ), a quasi-static solution was assumed. The calculated reaction rate taken at the beginning and end of each time interval was averaged and was-assumed to be constant over that interval; the nitrogen inlet flow rate was assumed to be equal to the nitrogen

$$
\text { AI-AEC-MEMO- } 12736
$$


outlet flowrate for each point. The results from each interval were totaled to get the final results.

Data from 95 points during the period from the start of steaming to the beginning of the 6-hr "zero-hydrogen" steaming (indicating that all sodium had been reacted) was used for the calculations. The calculations involved the use of compressible flow equations for orifice meters. A Fortran computer program was written to facilitate the numerical operations and to reduce the error which might have accumulated from hand calculations. The orifice flow equations were taken from Reference 8. A constant orifice discharge coefficient of 0.61 was assumed.

In addition to calculating the amount of sodium reacted, the computer program also included calculation of other parameters considered of significant interest during operation. A total of ten parameters was calculated for each data point.

1) Elapsed time in hours and minutes from the actual start of steaming operations

2) The steam inlet flowrate in $\mathrm{lb} / \mathrm{hr}$ based on the inlet steam orifice reading

3) The nitrogen inlet flowrate in scfm based on the inlet nitrogen orifice reading

4) Volume percent of steam in the inlet gas mixture based on steam and nitrogen inlet flowrates

5) Total steam inlet in pounds based on the summation of average steam flowrates over the individual time interval

6) Volume percent hydrogen in the condenser effluent gas, a part of the input data

7) Sodium reaction rate in $\mathrm{lb} / \mathrm{hr}$ based on the inlet nitrogen flowrate and the hydrogen concentration in the condenser effluent gas

8) Process operating efficiency in percent based on the calculated molal rate of steam reacting with sodium and the indicated rate of steam entering the reactor vessel, defined as zero for zero steam flow 
9) The amount of sodium reacted in pounds since the start of steaming operations based on the average sodium reaction rate calculated for each time interval

10) Total process efficiency in percent based on the calculated moles of sodium reacted and the calculated total steam inlet to the reactor since the start of steaming operations

Items 2), 4), 5), 8), and 10) are subject to some error due to the steam blowdown flow leaving the system after the inlet steam orifice meter. Derivation of the equations used in the program and a program listing are given in Appendices D-1 and D-3.

The computer program was planned to read the input data for one point, perform the necessary calculations, and then print the results; as opposed to reading all the data and then performing the calculations. Only those calculated values which were necessary for averaging or summing were retained for use with calculations on the next data point. The process operating efficiency was arbitrarily defined as zero for those few points where there was zero steam flow but a measurable hydrogen concentration was still indicated in the effluent gas. A check was also included to stop the program in the event of a calculated negative time interval which could occur if the data cards were loaded in the wrong sequence.

All data, shown in Appendix D-4, for calculation of the results was copied from data recorded by CPPD. A complete copy of the original data was not reproduced herein because most of the information recorded was used solely for monitoring the status of the reactor and steaming system during the steaming operation and during preoperation checks.

During the steaming operations, few readings were taken of the pressure on the upstream side of the steam and nitrogen inlet orifices. That these pressurcs were not monitored at every point was an oversight; the gages had been installed immediately before the start of operations and the identification numbers were left off of the data sheets inadvertently. After the steaming operation was completed, a short test was run to obtain additional data for correlating the mixing tank pressure reading with the flow meter readings and the orifice pressure readings. These test data, along with the readings which had been 
taken during the reactor and loop steaming operations, were used to establish an empirical relationship between the three readings. This relationship was then used for the main calculations. Derivation of the relationship is shown in Appendix D-2.

The printout of results from the computer calculations are shown in Table 3. Calculations indicate that a total of $483 \mathrm{lb}$ of sodium were chemically reacted with steam in the reactor vessel and connecting piping. An earlier run had indicated that approximately $700 \mathrm{lb}$ of sodium had been reacted, see Reference 9; however, a subsequent review of the calculation procedure disclosed the fact that the square root scale on the indicators for the steam and nitrogen flowmeters had been interpreted as being a linear scale. The computer program was then corrected and run again to give the present results.

Comparison of the process efficiencies in Columns 8 and 10 of the results printout, Table 3, show that the overall process efficiencies indicated in the earlier tests with a simulated reactor vessel were similar in magnitude, see page 6 of Reference 5. In fact, the reactor results data are practically equal to those for the longest, 16-hr, test. Higher process efficiencies, in the neighborhood of $18 \%$, were found for rather steady operating intervals near the be ginning of the reaction at Hallam. The calculated efficiency of $47 \%$ for the second point is misleading due to the previously high steam flow which was still affecting the hydrogen concentration. The initial high process efficiencies were due to the close proximity of sodium to the inlet line. Steam was first admitted to Line 41 which leads down, inside the reactor vessel, to within 2 in. of the bottom, near the periphery. The deepest portion of the sodium pool, $\sim 7 / 32$ in., was just under the pipe outlet.

No calculations were attempted for the amount of sodium reacted in the primary heat transfer loops, due to the wide swings in effluent hydrogen concentration, some of which were beyond the instrument range of $5 \%$ and the frequency with which manual controls had to be adjusted.

\section{Inspection Results}

After each steaming operation, reactor steaming and loop steaming, samples of sodium were taken from the primary system and inspected. Sodium samples were taken from the primary heat transfer loop piping by cutting a 
TABLE 3

HNPF RETIREMENT RESULTS FROM STEAMING OF REACTOR VESSEL

(Sheet 1 of 3)

HNPF RETIREMENT

RESUL TS FROM STEAMING OF REACTOR VESSEL

\begin{tabular}{|c|c|c|}
\hline $\begin{array}{l}\text { ELAP } \\
\text { TIME }\end{array}$ & SED & $\begin{array}{l}2 \\
\text { STEAM } \\
\text { FLCW } \\
\text { RATE }\end{array}$ \\
\hline$H R / M$ & IN & $L B / H R$ \\
\hline 01 & 0 & $117.34 \mathrm{C}$ \\
\hline $0 /$ & 28 & 46.520 \\
\hline $1 /$ & 0 & 57.246 \\
\hline $1 /$ & $3 C$ & $1 \mathrm{CC} .381$ \\
\hline 21 & 0 & 100.114 \\
\hline 21 & $3 C$ & 100.187 \\
\hline 31 & 0 & $57 . C 35$ \\
\hline 31 & 30 & 57.035 \\
\hline 41 & 0 & $57 . C 45$ \\
\hline 41 & 30 & 93.264 \\
\hline $5 /$ & 0 & 90.455 \\
\hline s/ & $3 C$ & 91.703 \\
\hline 61 & 0 & 52.133 \\
\hline $6 /$ & 30 & 91.497 \\
\hline 71 & $u$ & 51.508 \\
\hline 71 & 30 & 91.302 \\
\hline 81 & 0 & 90.946 \\
\hline 81 & 30 & 114.841 \\
\hline s/ & 0 & 139.695 \\
\hline $9 /$ & 30 & 129.711 \\
\hline 101 & 0 & 100.005 \\
\hline $1 \mathrm{Cl}$ & 30 & S5. 947 \\
\hline $11 /$ & 0 & 99.971 \\
\hline 111 & 30 & 102.184 \\
\hline 121 & 0 & 139.538 \\
\hline 121 & 30 & 142.351. \\
\hline 131 & 0 & $1=4 \cdot c 40$ \\
\hline $\begin{array}{l}131 \\
141\end{array}$ & 30 & $\begin{array}{r}192.489 \\
1507\end{array}$ \\
\hline 141 & $3 v$ & 191.135 \\
\hline $15 /$ & 0 & $19 \mathrm{C} .87 \mathrm{C}$ \\
\hline $15 /$ & 30 & $190.87 \mathrm{C}$ \\
\hline
\end{tabular}

3
NI TROGE
FLOW
RATE
SCFM
IC5.212
$104.69 C$
$1 C 4.713$
125.436
126.244
126.223
$1 C 5.542$
$1 C 4.491$
$1 C 4.432$
87.455
67.618
76.612
77.792
77.167
77.127
65.880
69.783
68.633
69.428
69.392
68.801
68.809
68.651
$7 C .049$
$7 C .065$
71.314
12.088
70.312
76.356
$7 C .160$
$7 C .166$
$7 C .210$

\begin{tabular}{lr}
\multicolumn{4}{|c}{} & 5 \\
VOLUNE & TOTAL \\
PFRCENT & STEAM \\
SIM. & INLET
\end{tabular}

INLET

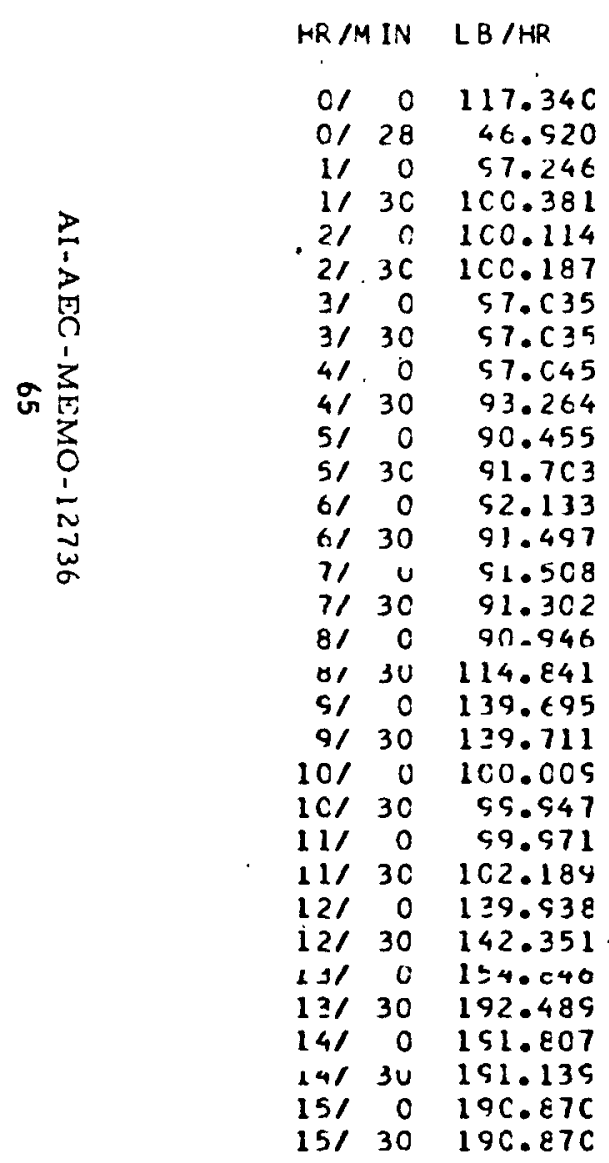

LB.

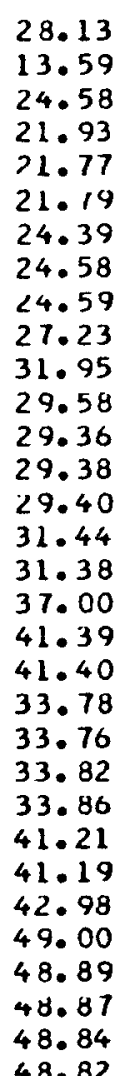

\begin{tabular}{ll}
\multicolumn{1}{c}{6} & \multicolumn{1}{c}{7} \\
VOLJME & SODIUM \\
PERCENT & REACT ION \\
HYO. & KAIE
\end{tabular}

$L B / H R$

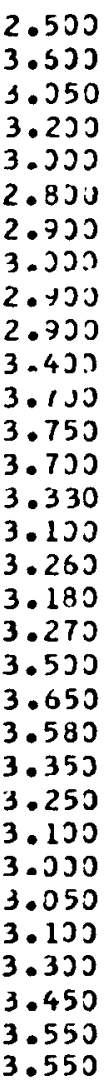

8
PROCESS
OPER.

EFP.

PERCENT

13.103

47.488

19.306

23.543

22.227

20.684

18.514

18.981

18.317

15.961

14.995

18.294

18.749

18.468

16.547

13.955

14.736

11.187

9.575

10.267

14.851

14.568

13.565

13.123

9.129

8.830

8.347

6.660

7.134

7.476

7.711

7.716
SOOIUM

REACTED

LB.

0.0

$25 .<11$

38.763

53.421

67.149

79.507

01.130

102.692

113.125

122.213

131905

142.782

153.698

163.933

181.191

180.576

197.953

206.808

216.115

225.532

234.515

243.131

251.496

259.592

267.736

275.960

284.427

293.362

302.629

312.035
10

POTAL

EFF.

PERCENT

0.0

22. 925

25.706

24.043

23. 714

23.214

22.571

21.998

21.562

21.064

20.515

20.171

20.035

19.927

19.756

19.460

19.146

18.731

18.104

17.486

17.164

17.045

16. $90 \mathrm{R}$

16.749

16.449

16.033

15.620

15.121

14. 603

14.171

13.805

13.484 
TABLE 3

HNPF RETIREMENT RESULTS FROM STEAMING OF REACTOR VESSEL (Sheet 2 of 3)

HNPF RETIREMENT

RESUR TS FROM STEAMING OF REACTOR VESSEL

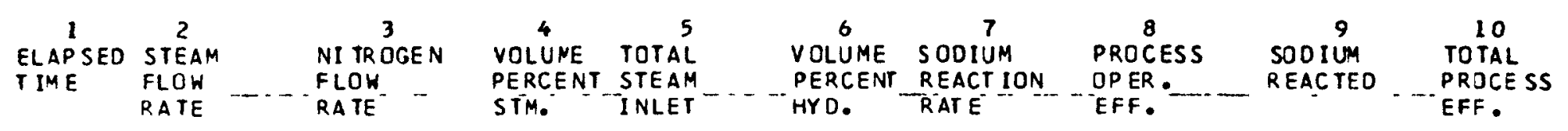

HR/MIN LB/HR SCFM LB.

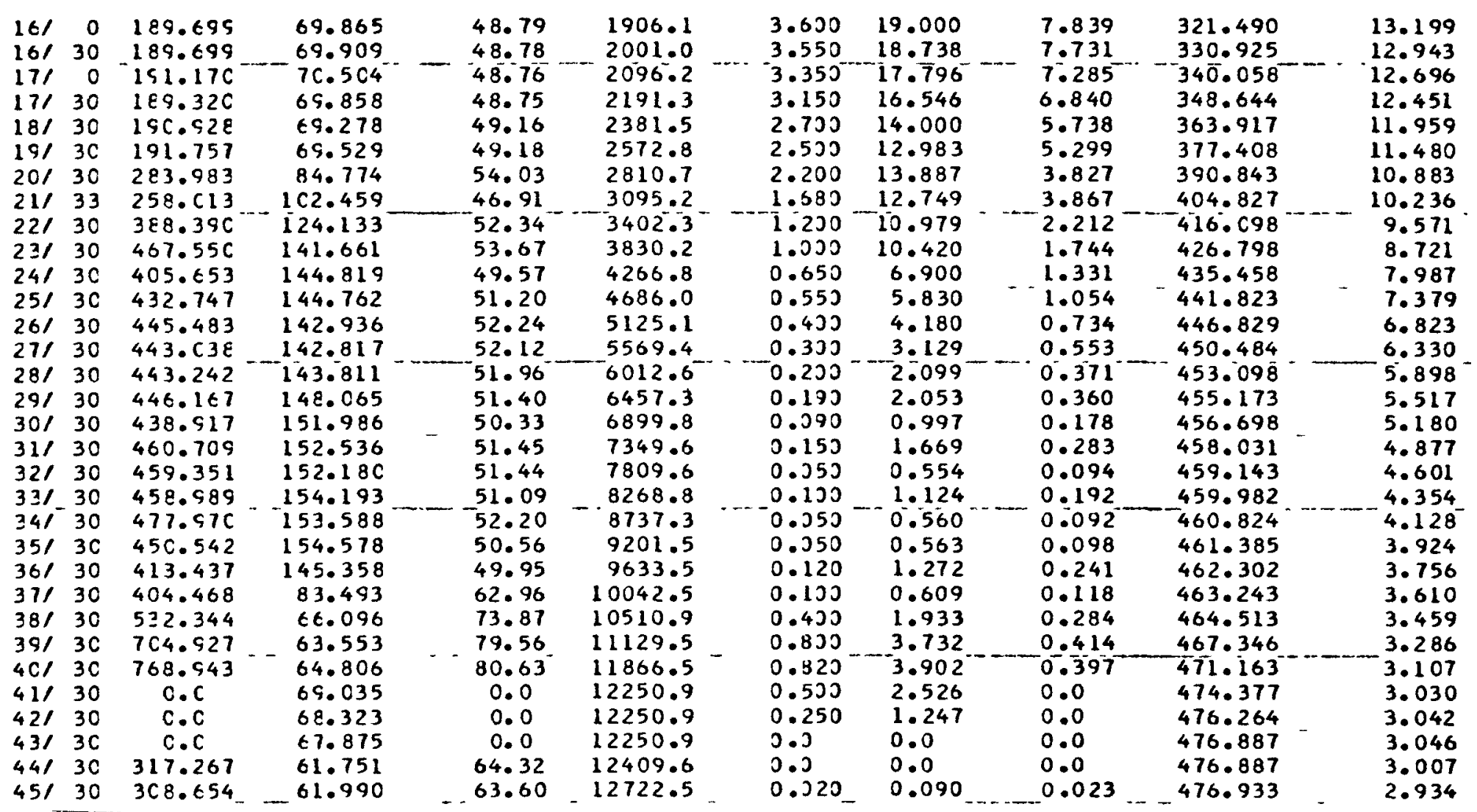


TABLE 3

HNPF RETIREMENT RESULTS FROM STEAMING OF REACTOR VESSEL (Sheet 3 of 3 )

HNPF RETIREMENT

RESUL TS FRUM STEAMING OF REACTOR VESSEL

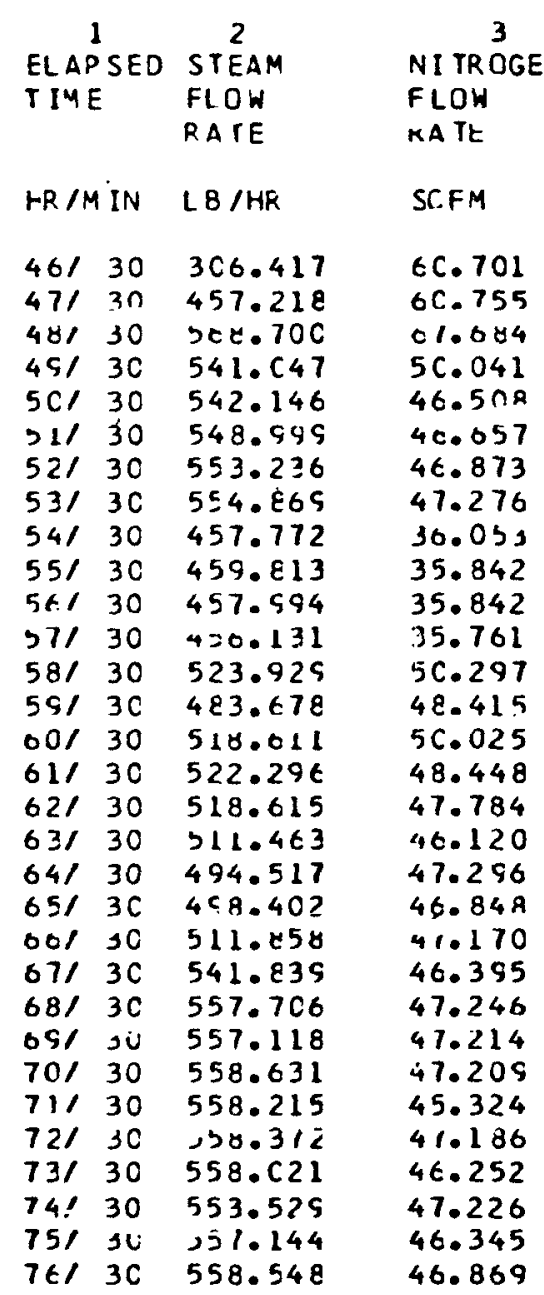

$$
\begin{array}{lr}
\multicolumn{4}{c}{4} & 5 \\
\text { VOLUNE } & \text { TOTAL } \\
\text { PERCENT } & \text { STEAM } \\
\text { SIM. } & \text { INLET }
\end{array}
$$

$$
\text { LB. }
$$

63.92
72.53
74.67
79.14
80.36
80.50
80.55
80.46
81.67
81.82
81.77
81.74
78.52
77.81
78.44
79.09
79.20
79.56
78.58
78.87
14.20
80.39
80.55
80.55
80.59
81.21
80.59
80.89
80.44
80.84
80.70

\section{1} 13411.9 13424.8 14479.7 15071.3 15060.4 13566.4
16118.0 16118.0
16672.1 17178.4 17637.2 $1809 \mathrm{~K} .1$ 18553.1 19043.2 19547.0 20048.1 20568.6 21089.0 21604.1 22107.0 22603.5 23108.6 23635.5 24185.3 24742.7 25300.5 25859.0 26417.3 26975.5 27531.2 28086.6 28644.4

\begin{tabular}{ll}
\multicolumn{1}{c}{6} & \multicolumn{1}{c}{7} \\
VOLUME & SODIUM \\
PERCENT & REACT ION \\
HYD. & RATE
\end{tabular}

\section{LB/ HR}

0.100

0.113

0.110

0.130

0.160

0.080

0.080

0.360

0.353

0.023

0.250

0.050

0.050

0.5

0.3

0.553

0.325

0.0

0.0

2.5

0.340

0.340

0.170

0.150

0.1050

0.330

0.310

ט. 010

0.0

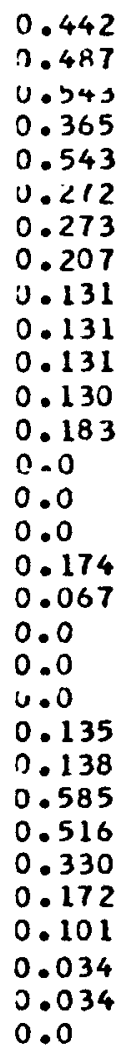

8
PROCESS
OPER.
EFF.

PERCENT

0.113 0.083

0.083
0.075

0.053

0.078

0.039

0.039

0.029

0.022

0.022

0.022

0.022

0.027

0.0

0.0

0.0

0.026

0.010

0.0

0.0

0.0

0.020

0.019

0.402

0.072

0.046

0.024

0.014

0.005

0.005

0.0

$\stackrel{9}{\text { SO OIUM }}$
REACTED

LB.

477.199

477.664

478.179

478.633

479.086

479.494

479.766

480.006

480.175

480.306

480.437

480.567

480.724

480.816

480.816

480.816

480.903

481.023

481.057

481.057

481.057

$481 \cdot 125$

491.261

481.623

482.174

482.597

482.848

482.985

483.052

483.087

483.103
TOTAL

PROCE SS

EFF.

PFRCENT

2.866

2. 787

2.687

2.587

$2.49 h$

<.411

2.330

2. 253

2.188

2.131

2. 078

2. 027

1. 976

1. 925

1.817

1. 829

1.785

1.743

.703

1.666

1. 629

1. 593

1.557

1.323

1.491

1. 461

1.430

1.401

1.373

.340

$1+C 2171$

TRACEEACK FOLLOWS- ROLTINE ISN REG. 14 
4-in.-diameter hole in the top of the pipe wall and scraping out a sample. The sample holes were subsequently welded closed. The sample location for the loop piping was at the ends which connected to the steaming system. This was a low point to which liquids would drain. Since scraping for a sodium sample in the reactor vessel was impractical, sodium samples were placed in special containers and suspended inside the reactor vessel prior to the steaming operation, see Section VI of Appendix B. The samples were removed and inspected after completion of various stages of the steaming operation.

\section{a. Reactor Vessel Results}

The first two sodium sample sets, 2 cups, were removed from the reactor vessel after steaming for $6 \mathrm{hr}$ with zero hydrogen indication in the effluent gases. The following is a quotation from the operators log book on the condition of sample in each cup:

"Both samples were identical in appearance when removed from the reactor. The samples were in a liquid state and a reddishbrown color. They began to set up immediately into a bluish gelatin appearing semi-solid. Before setting up, both samples were probed for particulates. Only one solid piece of solid matter was found, that being in the bottom portion from $\mathrm{C}-128$. This particle about the size of a match head was put into a water sample and no reaction occurred."

Based on the lack of evidence of unreacted sodium in the sample and the 6-hr of steaming with zero hydrogen indicated in the effluent gases, it was concluded that all residual sodium in the reactor vessel had been reacted chemically. The vessel preheaters were then turned up to $450^{\circ} \mathrm{F}$ and a $24-\mathrm{hr}$ purge with hot 350 to $400^{\circ} \mathrm{F}$ nitrogen started.

At the end of a 24-hr period, a sample of the effluent nitrogen was cooled from 468 to $74^{\circ} \mathrm{F}$, and the humidity was measured. The relative humidity was less than $2 \%$ at $74^{\circ} \mathrm{F}$. This corresponds to a relative humidity of less than $0.002 \%$ at the effluent temperature of $468^{\circ} \mathrm{F}$. The four remaining sample sets

*Consumers Public Power District, Sheldon Station; Reactor Steaming System Log, entry at 0500 on April 12, 1958 
were then removed and inspected. All samples had solidified and there was no evidence of unreacted sodium when they were mixed with water.

b. Primary Heat Transfer Loop Results

Each of the three heat transfer loops were steamed with $75 \%$ steam entering the loop until the effluent hydrogen concentration indicated zero for at least $3 \mathrm{hr}$. After the 3-hr period, the loops were dried by purging each with hot nitrogen until the relative humidity of the effluent nitrogen was less than $1 \%$. Afte $r$ the loops had been dried, samples of the residue were taken from each of the six main pipe ends, two for each loop, where available. Two of the lines, No. 232 and 233, did not have enough residue for a sample. All samples taken were solid and showed no sign of unreacted sodium when they were mixed with water.

3. Potential Effects of Residue

The interior of the reactor vessel is considered to be a posibly dangerous source of radiation for a period of 100 years. In order to assure that the integrity of the vessel will be maintained for at least that period, an investigation was made of the potential effects of the sodium hydroxide on the vessel material. A complete description of the investigation and its results are given in Reference 10 .

The principal conclusions of this investigation were as follows.

1) After completing the planned sealing operations for the vessel, it will be subject to a passive environment and no significant corrosion due to the caustic will occur.

2) The introduction of water or air into the vessel, by seepage or other means, will not measurably change the corrosion due to the caustic.

3) The low stress levels in the reactor vessel and the insignificant amounts of chlorides and sulfates in the residue are not sufficient to promote stress corrosion.

Based on the foregoing conclusions, it is estimated that the integrity of the reactor vessel will be maintained more than the required 100 years.

AI-AEC-MEMO- 12736 
$$
\text { . }
$$ 


\section{DISPOSAL OF SODIUM SERVICE PIPING}

\section{A. REMOVAL OF SECONDARY SODIUM SERVICE PIPING}

The preparation for the removal of the secondary sodium system was initiated with the removal of the insulation, heaters, and reflectors from the sodium piping and sodium system components. This facilitated separation of the sodium piping from the system components.

The secondary sodium service piping was separated from a system component by use of a pipe cutter at the stub joint. A stainless steel seal plate with a stainless steel bar stock valve was welded over the open stub joint to the system component. A plastic cap was then taped over the open end of the pipe.

A nitrogen gas line was connected to the stainless steel bar stock valve in the seal plate and the secondary sodium system was purged with nitrogen both to prevent the residual sodium in the system from reacting with the atmospheric moisture and to retain an inert atmosphere within the system.

The secondary sodium service piping was separated from all system components and then each section of pipe, if too long to remove from the pipe ways, was cut at the tees and bends to facilitate removal from the below grade areas to the reactor high bay for storage. The pipe hangers were removed and the system components were blocked in place as sections of pipe were removed and transferred from the pipe ways and. to the system component bay to the reactor high bay.

\section{B. CLEANING OF SECONDARY SODIUM SERVICE PIPING}

The secondary sodium service piping was transferred from its storage area in the reactor high bay to the sodium disposal facility for cleaning after all the piping had been removed from the system.

Approximately $627 \mathrm{ft}$ of secondary service piping was cleaned in the sodium disposal facility, Figures 32 and 33. After cleaning, the pipe was transferred to the pipe scrap pile south of the reactor building to be disposed of as clean scrap.

$$
\text { AI- } \triangle E C-M E M O-12736
$$




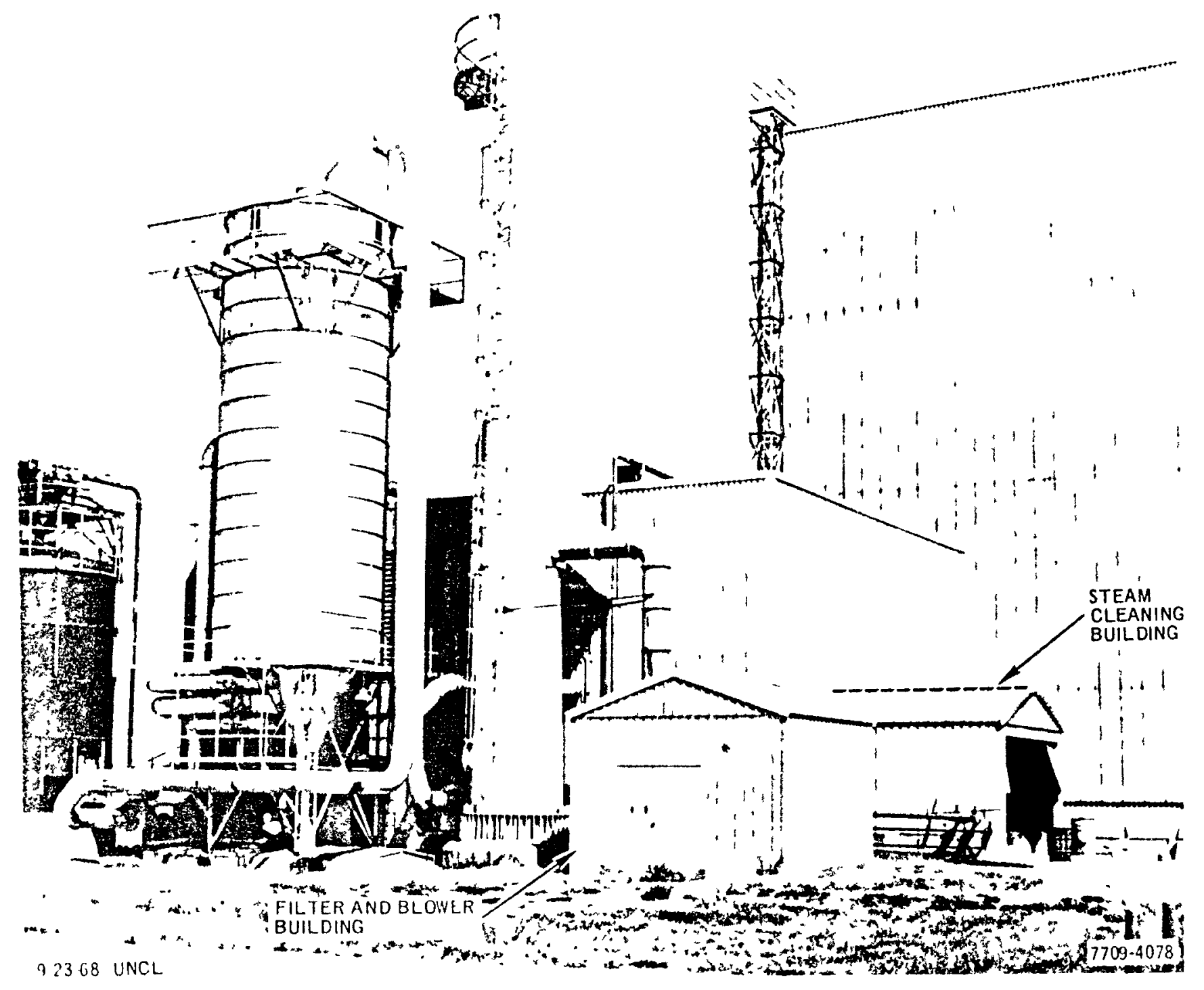

Figure 32. Sodium Disposal Facility Buildings 


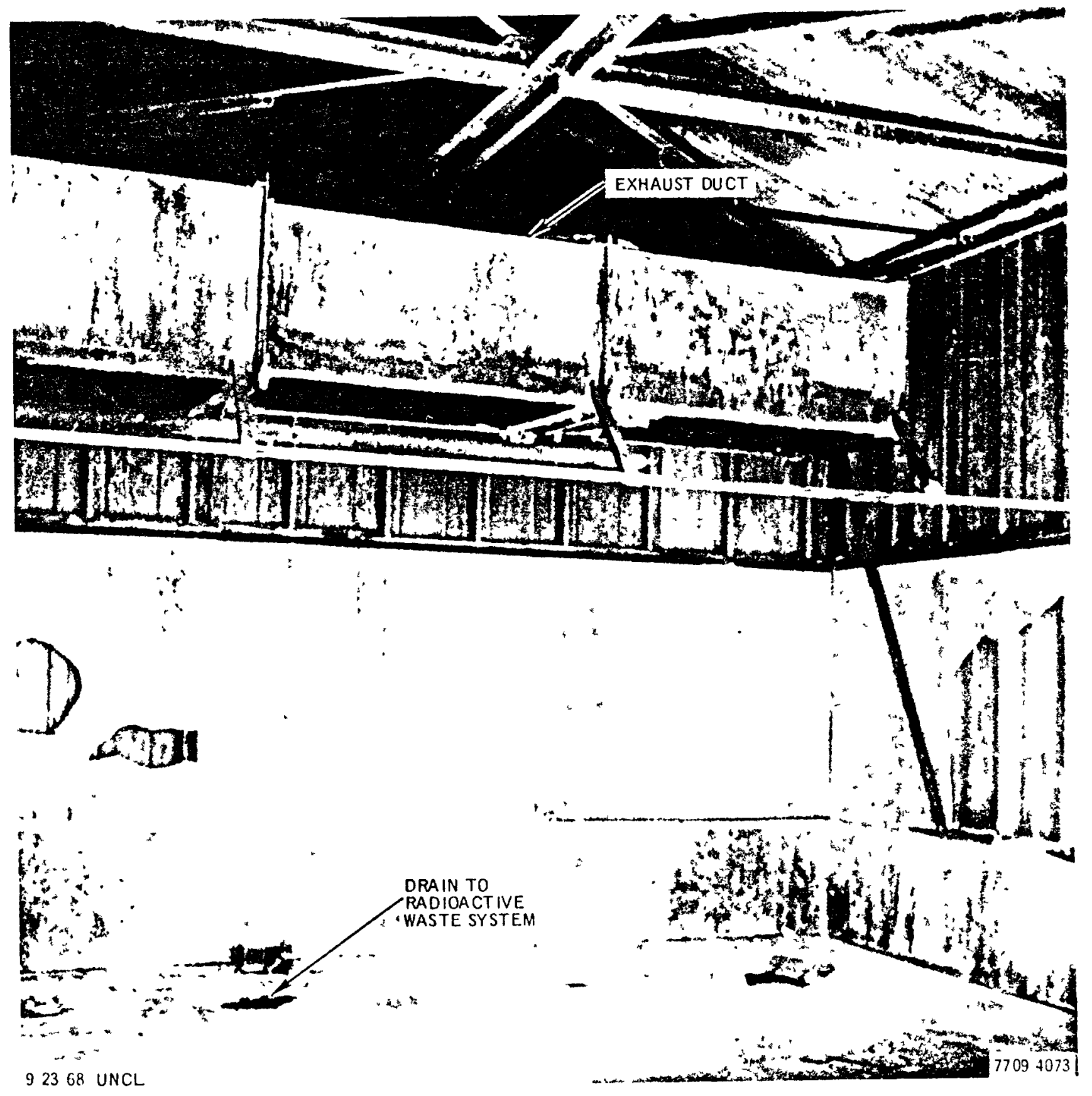

Figure 33 Interior of Sodium Cleaning Bullding

\author{
AI-AEC-MEiNO-12736
}




\section{REMOVAL OF PRIMARY SODIUM SERVICE PIPING}

The primary sodium service piping was removed from the primary service system in accordance with HNPF Retirement Activity Specification No. 5, Reaction of Residual Primary Sodium and Retirement of Primary Sodium System; and detailed procedure RDP-5-1, Isolation of Primary Sodium Service System and Disassembly of System.

The primary sodium service piping was prepared for removal in the same manner as that for the secondary sodium system by removing the pipe and system component insulation heaters and reflectors to facilitate the cutting of the pipes first at the juncture of the system components and by cutting at pipe tees and pipe bends to facilitate removal for cleaning. As a section of pipe was separated from a system component, the opening to the component was closed by welding a stainless steel seal plate over the opening. A stainless steel bar stock valve in the seal plate was used in purging the system with nitrogen to retain an inert atmosphere within the system.

\section{CLEANING OF PRIMARY SODIUM SERVICE PIPING}

The dismantled primary sodium service piping was removed from the below-reactor-grade areas and was transferred to the sodium disposal facility for cleaning and reacting of residual sodium. There was approximately $4088 \mathrm{ft}$ of primary service pipe cleaned and approximately $3800 \mathrm{lb}$ of sodium removed from the pipe and reacted in the sodium disposal facility. All sections of the primary sodium service piping were surveyed for contamination, by the HNPF health and safety personnel; all of the pipe was found to be clean and was placed in the scrap metal yard. 


\section{REMOVAL AND DISPOSITION OF MAJOR COMPONENTS}

\section{A. MAIN SODIUM BLOCK AND THROTTLE VALVES}

The removal of the main primary sodium block and throttle valves was performed in accordance with HNPF Retirement Activity Specification No. 5, Reaction of Residual Sodium and Retirement of Primary Sodium System; and detailed procedure RDP-5-2, Removal of Primary Sodium Block and Throttle Valves and Isolation of the Reactor from its Related Systems. The main secondary sodium block and throttle valves were removed in accordance with HNPF Retirement Activity Specification No. 6, Reaction of Residual Secondary Sodium and Retirement of Secondary Sodium System; and detailed procedure RDP-6-5, Removal of Secondary Heat Transfer Piping and Components.

The main primary sodium block and throttle valves were located in the east and west pipe gallerys just out of the reactor cavity below access plugs No. $9 \mathrm{~A}$ and $9 \mathrm{~B}$.

The pneumatic valve operators, pipe hangers, and valve structural supports were removed to provide access for the pipe cutter used in separating the valves from the main primary sodium pipe lines. Temporary blocking was used to support the valves and piping until the valves could be removed.

The valve and pipe insulation, heaters, and reflectors were also removed to provide access for the pipe cutter. After separating the valves from the system, plastic caps were placed over the inlet and outlet openings of the valves. The reactor side and the system side of the sodium pipe was sealed by welding a stainless steel pipe cap over the open line. Each pipe cap was fitted with a 2 -in. capped stub end for future connection to the steaming system.

The main primary sodium throttle valves were removed as an assembly with the main primary sodium check valve. The throttle and check valve were raised from the below-reactor-grade pipe-way to the reactor high bay by use of the high bay $60-$ ton crane. The throttle and check valve were then separated by use of a pipe cutter on the reactor high bay floor. There were three main primary sodium block valves and three main primary sodium throttle and check valves. After the valves were removed from the primary system and transferred to the reactor high bay, the plastic caps were removed from the valve

$$
\text { AI-AEC-MEMO-12736 }
$$




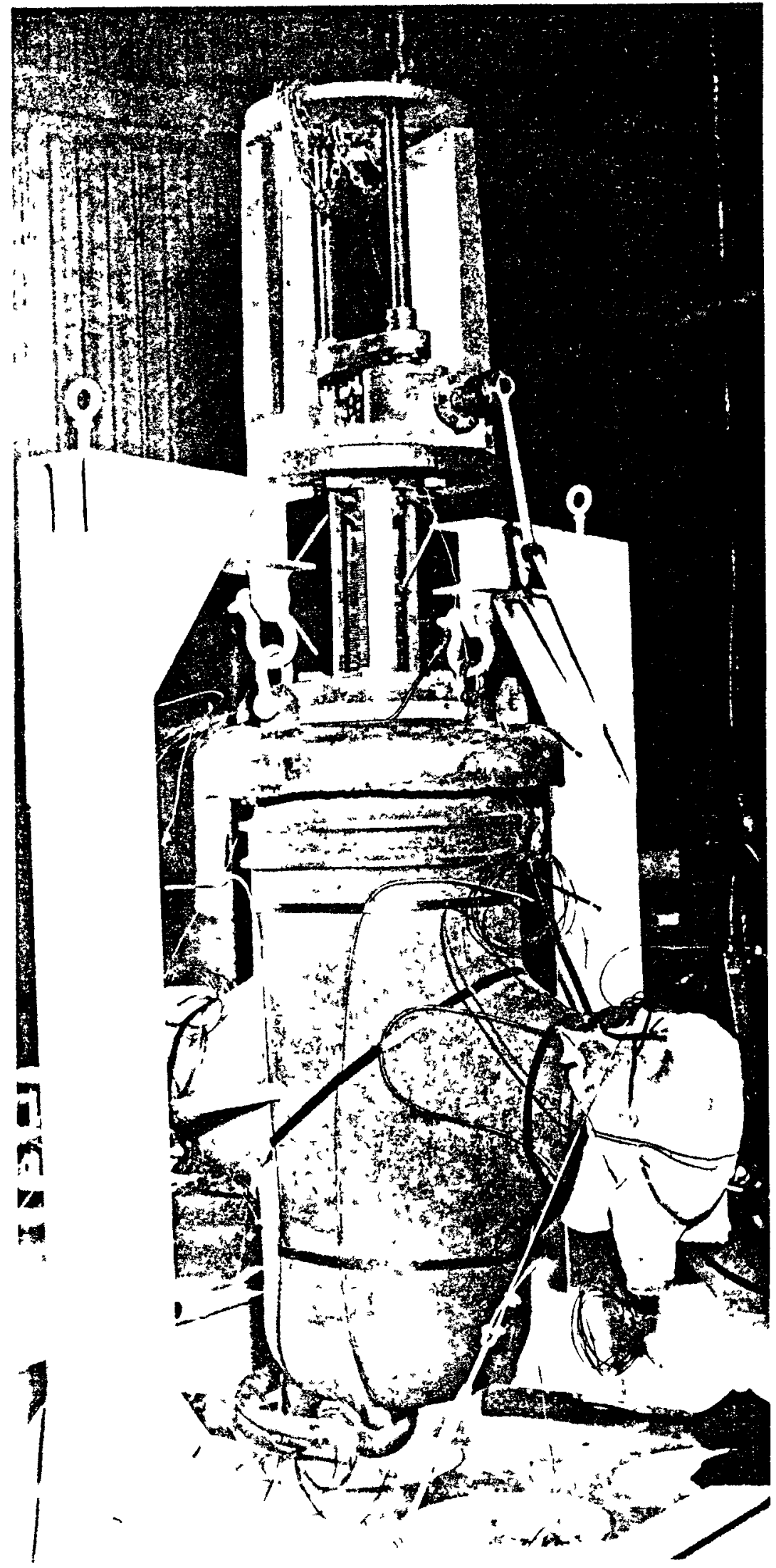

$7694-5465$

Figure 34. Primary Sodium Block Valve After Cleaning at Santa Susana 
inlet and outlets and were replaced by welding a stainless steel seal plate over the openings. The valves were then crated for shipment off site.

The main secondary sodium throttle valves were removed in a similar manner to that used for the main primary sodium valves. There were no block or check valves in the main secondary sodium system.

The three main primary sodium, block, check, and throttle valves together with the three main secondary sodium throttle valves were shipped to the Liquid Metals Engineering Center at Santa Susana, California. Figures 34 and 35 show the primary sodium block and throttle valves after arrival at Santa Susana.

\section{B. STEAM GENERATORS AND RELATED COMPONENTS}

The three steam generators, each consisting of an evaporator, a superheater, and an eliminator, Figure 36, we re isolated from the sodium system and removed from the steam generator rooms as outlined in HNPF Activity Specification No. 6, Reaction of Residual Secondary Sodium and Retirement of Secondary Sodium System; and detailed procedure RDP-6-4.

The isolation of the steam generator system began in March 1968 with the isolation of the steam generators, superheaters, and evaporators from the secondary sodium system and the interconnecting pipe lines between each component. Steèl seal plates were welded over each opening where pipe connection was separated from the component. One seal plate on each component contained a bar stock valve to facilitate leak checking of the welds of the seal plates.

It was necessary to remove the heating and ventilating ducting, ladders, and elevated catwalks from the steam generator rooms to facilitate the removal of the steam generators and system components. Wood cribbing-and-blocking was used to support the components until removed for shipping off site.

During the isolation of the superheater and evaporator vessels, cradle extension assemblies were installed on the vessels to provide support for the vessel during shipment.

The steam generators, superheaters, and evaporators were shipped by rail to Idaho Nuclear Corp. NRTS, Central Facilities Area, Scoville, Idaho

for storage. The shipments were completed in Junc 1968.

$$
\text { AI - AEC - MEMO- } 12736
$$




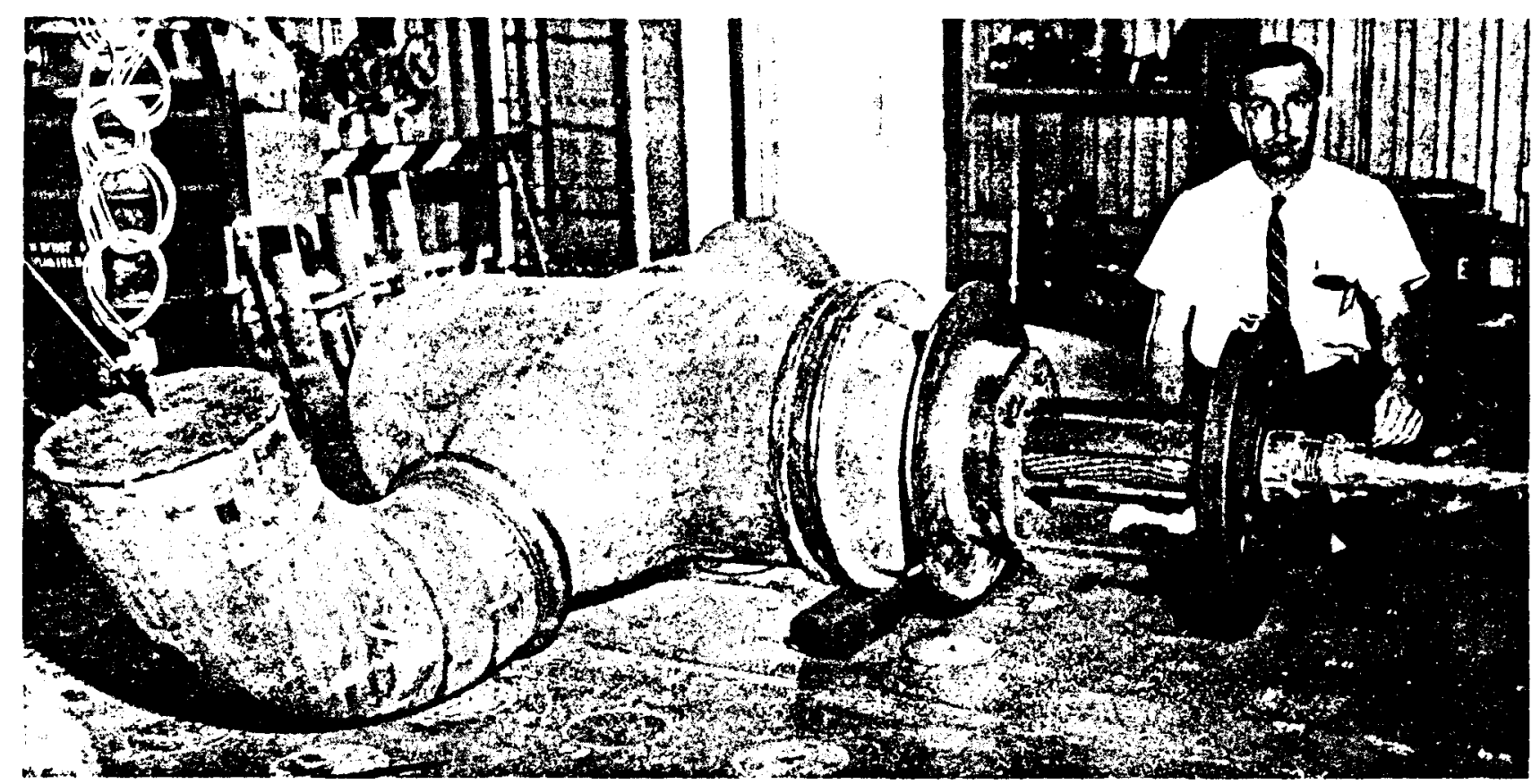

7694-5463

Figure 35. Primary Sodium Throttle Valve After Arrival at Santa Susana
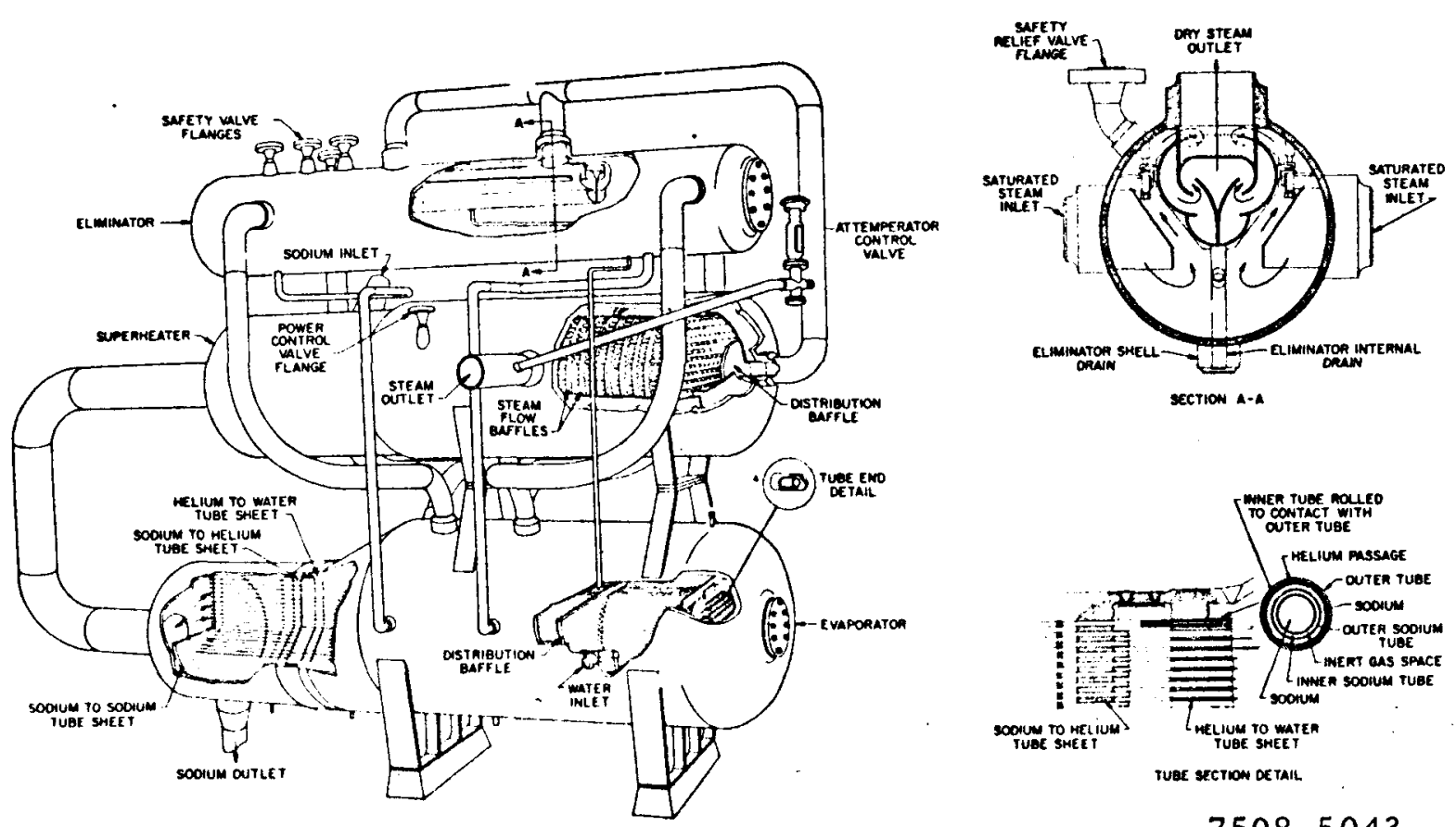

$7508-5043$

Figure 36. HNPF Steam Generator Assembly 


\section{INTERMEDIATE HEAT EXCHANGERS}

The intermediate heat exchangers, Figure 37, were isolated from the reactor sodium systems as outlined in Activity Specifications No. 5, Reaction of Residual Primary Sodium and Retirement of Primary Sodium Systems; and No. 6, Reaction of Residual Secondary Sodium and Retirement of Secondary Sodium Sys tem. Also followed, we re detailed procedures RDP 5-3, Isolate Intermediate Heat Exchanger Modules from their related Primary System; and RDP 6-2, Isolate the Intermediate Heat Exchangers from their related Secondary Systems.

The isolation of the IHX modules included cutting of the primary and secondary main heat transfer piping outboard of the inlet and outlet nozzles of the modules, welding of closure plates onto the remaining line stubs, and cutting and capping the vent lines which had been used to vent the secondary sodium side of the modules to the expansion tanks.

Bar stock valves were attached to the primary loop inlet and outlet nozzle closure plates and the secondary loop vent nozzles closure plates. These bar stock valves were installed during the module isolation to provide a means of maintaining an inert gas atmosphere in the modules. These valves remained on the modules during shipment and storage. Isolation of the Intermediate Heat Exchangers began in January of 1968.

Following the isolation of the modules and prior to their removal from the vaults, bellows support braces and guide locking plates were installed on the module bellows on the shell side to retain the modules in a rigid position within their support frames, for removal and shipment.

An intermediate heat exchanger module with its support frame was removed from its position in the vault, Figure 38, by use of the reactor high bay crane and was held in an upright position while a shipping skid was attached to the side of the support frame; then the IHX module, support frame, and shipping skid we re tilted down to the reactor high bay floor and prepared for shipment, Figure 39. The six Intermediate Heat Exchanger Modules were all shipped by truck to Idaho Nuclear Corp., NRTS, Central Facilities Area, Scoville, Idaho. The final shipment was made in June of 1968. 


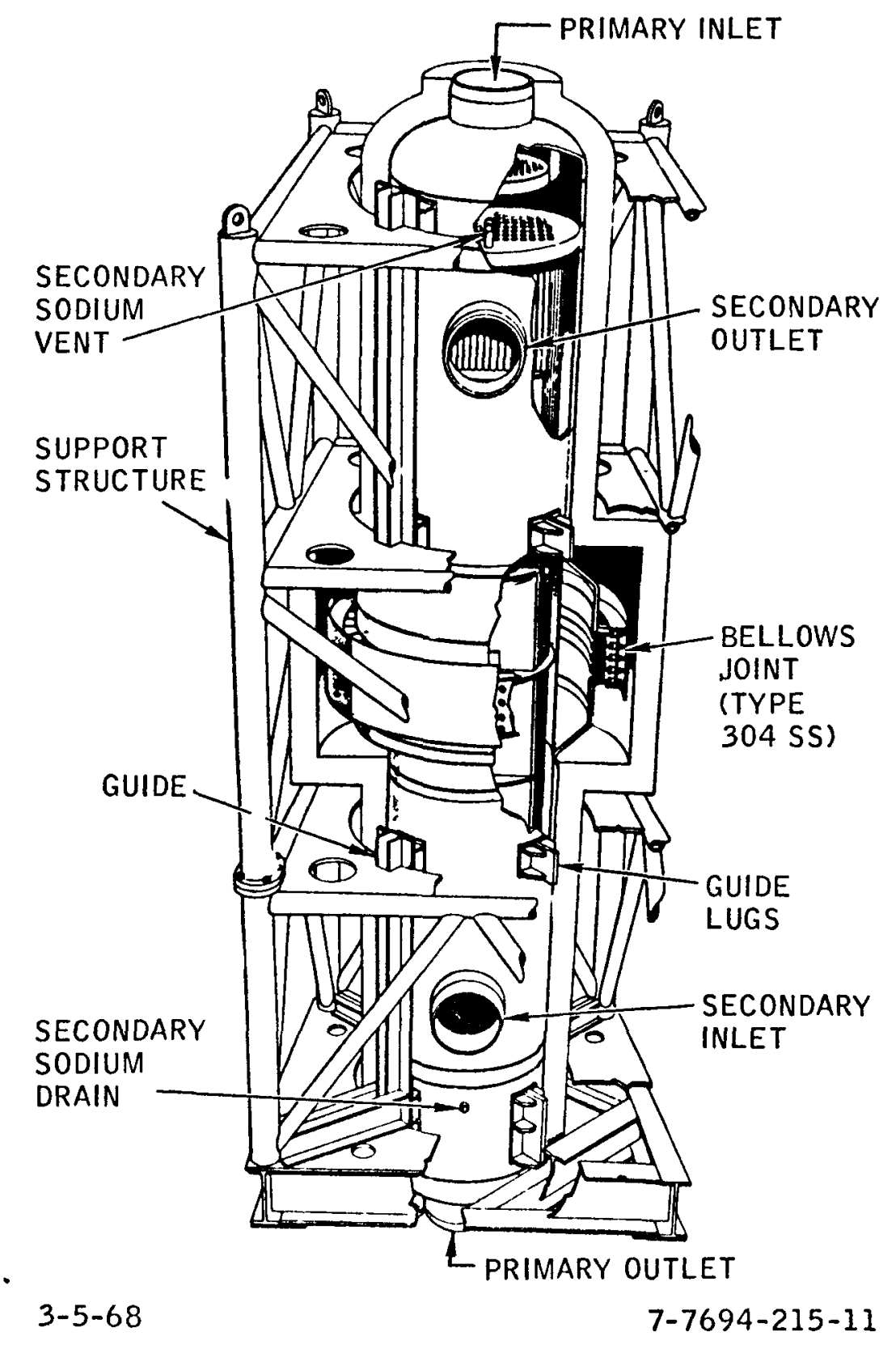

Figure 37. HNPF Intermediate Heat Exchanger 


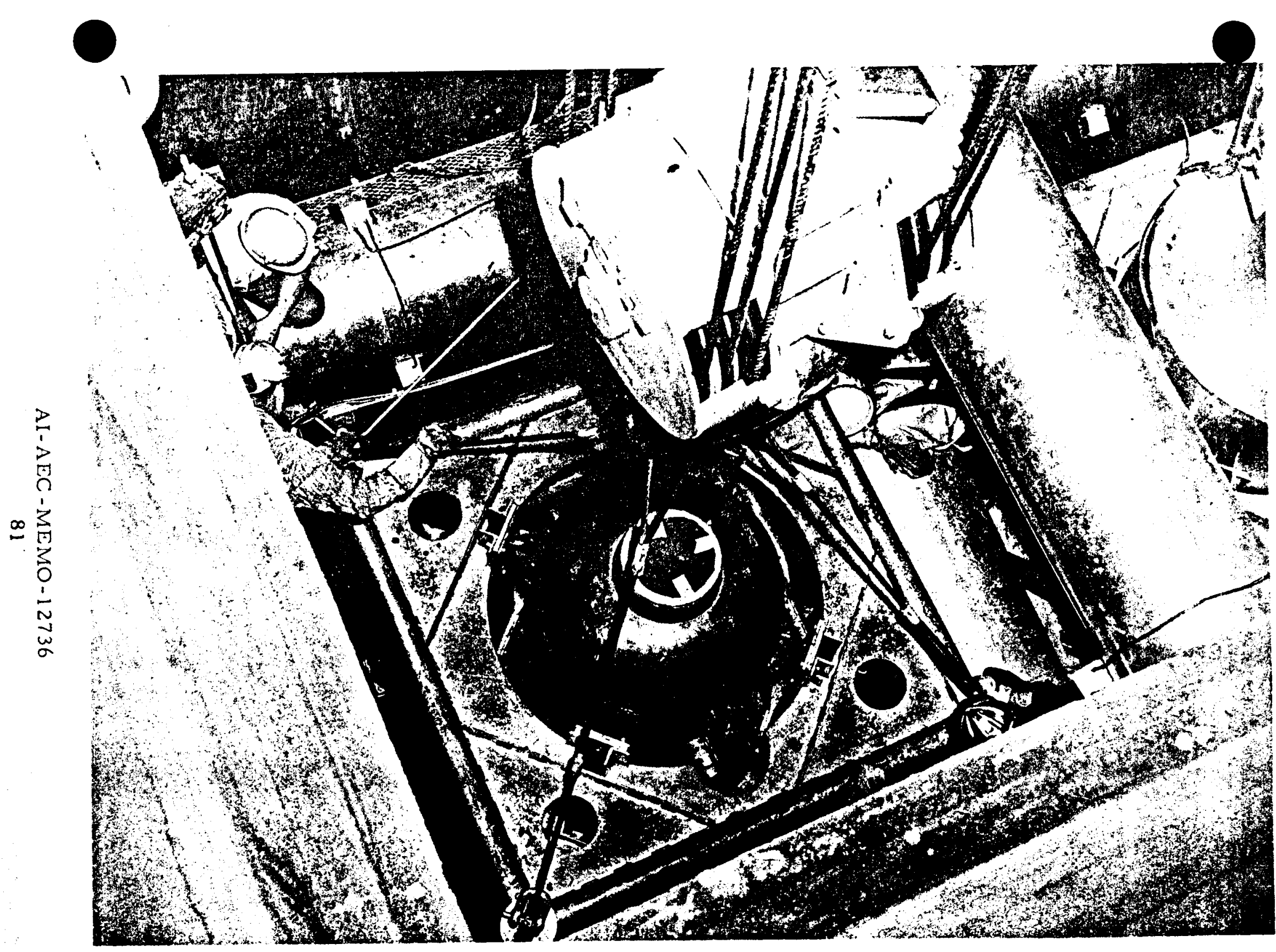

Figure 38. IHX Module Being Removed from Vault 


\section{PUMP REMOVAL}

\section{Primary Sodium Pumps}

The removal of the primary sodium pumps was performed in accordance with Retirement Activity Specification No. 5, Reaction of residual Sodium and Retirement of Primary Sodium Systems.

The three primary sodium pumps, Figure 40, were located north of the reactor and in a line parallel to the intermediate heat exchanger isolation structure.

To initiate the removal of the primary sodium pumps, the electrical services and instrumentation lines were disconnected. The oil seal pump and sodium piping were then disconnected from the pump. The pump motor and bearing seal assemblies were removed from the pump assemblies and stored in a temporary storage area above the IHX cells. The pumps were then removed from their outer casings and were transferred to the pump wash cell. After the pumps were removed from their outer casings, a gasketed steel plate was installed over the outer pump casings to provide a gas tight seal for the primary sodium system.

After the first wash cycle, each pump was removed from the wash cell for visual inspection. The pump diffusers were then removed, and the inner barrel and impeller were returned to the wash cell for a second washing. The pump assemblies were transferred to Pit 19 in the reactor high bay where the impellers were removed from the inner barrels. The inner barrels were then transferred to the wash cell for a third washing. The pump diffusers and im pellers were also rewashed in the pump wash cell; and after washing, each part was hand washed with acetone for a final decontamination. The pump parts were then reassembled for shipment.

The primary sodium pump motor, bearing seal assemblies, and pump assemblies were crated and shipped to the Idaho Nuclear Corp., NRTS, Central Facilities Area, Scoville, Idaho for storage.

The outer pump casings remained in the primary sodium loops until the loops were steam cleaned. They were then removed from the primary sodium system and shipped to Scoville, Idaho for storage with the pumps. 


\section{PRIMARY PUMP:}

IMPELLER DIAMETER: 59 in. BOWL DIAMETER: 109 in. BARREL DIAMETER: $\quad 67 \mathrm{in.}$ LENGTH OF BARREL: $\quad 22 \mathrm{ft}$ SUCTION NOZZLE: $\quad 36$ in. DISCHARGE NOZZLE: $32 \mathrm{in.}$
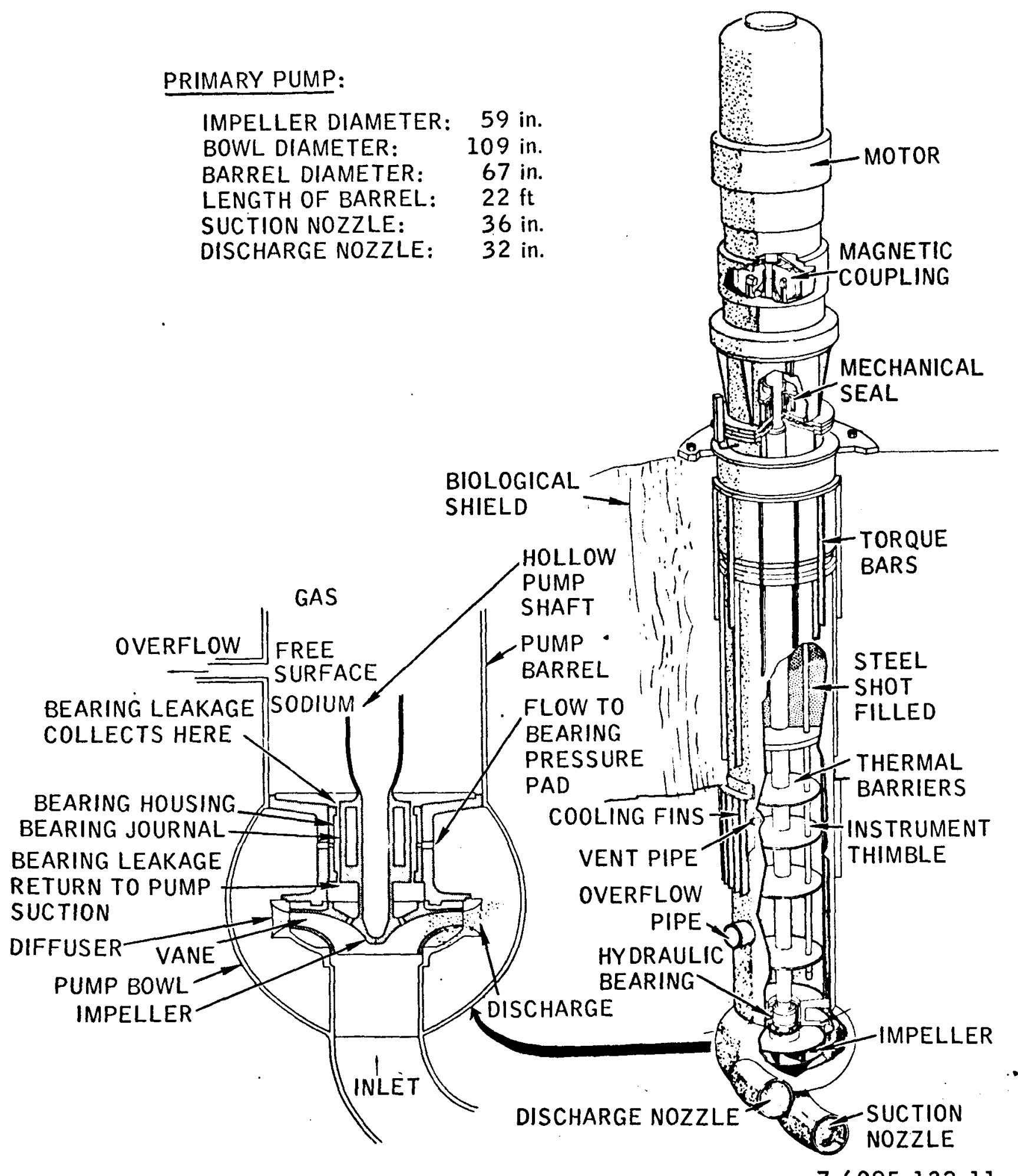

Figure 40. Free-Surface Sodium Pump 
The primary pump balancing-legs disconnected from the primary sodium pumps during the pumps separation from the primary sodium system were considered to be scrap and were shipped to Beatty, Nevada for burial.

\section{Secondary Sodium Pumps}

The removal and shipment of the three secondary sodium pumps was performed in accordance with Retirement Activity Specification No. 6, Reaction of Residual Secondary Systems; and detailed procedure RDP-6-1, Isolation of the Secondary Sodium Service System and Disassembly of the System.

To initiate the removal of the secondary sodium pumps, the electrical services, instrumentation connections, and the oil seal pump were disconnected from the three secondary sodium pumps. The pump drive motors and bearing seal assemblies were then removed from the pump assemblies and placed in temporary storage on the reactor high bay floor on shipping skids designed and fabricated to support the pump drive motor assemblies until packaged for shipment. The pumps were then removed from their outer casing and transferred to the pump wash cell for cleaning. After washing, the pump assemblies were transferred to Pit 19 and disassembled; each pump component was individually washed in the wash cell. The secondary pumps were not reassembled after washing, but were packaged in separate crates for shipment.

The secondary sodium pumps were shipped to the Liquid Metals Engineering Center, Santa Susana, California on October 9, 1967.

The outer secondary pump cases were sealed and removed from the secondary sodium system according to detailed Procedure RDP-6-3, Isolate and Remove the Secondary Pump Cases from their Related Systems. The secondary pump cases were not washed. A gasketed steel plate was installed over the pump casing before it was removed from the secondary sodium system. The inlet and outlet pipes were sealed by welding a seal plate over the opening of the pipe stubs.

One secondary sodium pump casing was shipped to the Liquid Metals Engineering Center, Santa Susana, California. The remaining two secondary pump cases were shipped to Idaho Nuclear Corp., NRTS Central Facilities Area, Scoville, Idaho for storage. 


\section{Sodium Service EM Pumps}

There were four electromagnetic pumps in the HNPF sodium service systems. One EM pump was used as a sodium transfer pump to transfer sodium from the sodium loading station to the sodium storage tanks, another of the EM pumps was in the secondary service system. The EM transfer and secondarysodium pumps were not contaminated. These were removed from the sodium system during the removal of the secondary sodium system piping and were shipped to Pacific Northwest Labs, Richland, Washington in April of 1968.

The remaining two EM pumps were located in parallel in the primary sodium service system and were removed from that system during the removal of the primary sodium service system piping. The throat sections and connecting pipe stubs from the primary sodium EM pumps were contaminated with radioactive material. They were considered to be radioactive waste and were shipped to Beatty, Nevada for burial. The primary EM pump coils, cage, frames, and capacitors were packaged and shipped to the Liquid Metals Engineering Center, Santa Susana, California. 


\section{REFERENCES}

1. "Hallam Nuclear Power Facility Retirement Plan, Revision 4 (October 10, 1966)" NAA-SR-MEMO-12209, p 6

2. R. R. Stiens and T. J. Boardman, "HNPF-Proposed Methods for Removal and Shipment of Bulk Sodium, " NAA-SR-MEMO-12269 (March 27, 1967)

3. R. J. Boardman and S. Sudar, "Reaction of Residual Sodium in HNPF Primary Sodium Systems, " NAA-SR-MEMO-12268

4. J. H. Perry, "Chemical Engineers' Handbook," 4th ed., McGraw-Hill Co., New York (1963)

5. F. W. Poucher, "HNPF Steam-Sodium Reactor Tests," AI-AEC-TDR12714 (June 21, 1968)

6. P. W. Mullen, "Modern Gas Analysis," Interscience Publishers, p 137 (1955)

7. F. W. Poucher, "Sodium-Air Reaction Test at Ambient Conditions," NAASR-T DR - 12403

8. N. C. Ebaugh, "Engineering Thermodynamics," Lancaster Press, p 114 and 115 (1937)

9. "Monthly Retirement Report No. 21," April 1968; Hallam Nuclear Power Station, Sheldon Station, Consumers Public Power District, p 25

10. J. W. Wunderlich et al., "Potential Effects of Sodium Hydroxide on the HNPF Reactor Vessel - Hallam Retirement Program," AI-AEC-MEMO12733 (August 9, 1968) 
$$
\text { . }
$$ 
APPENDIX A

SPECIFICATIONS AND PROCEDURES

AI-AEC-MEMO- 12736

89 


\section{LIST OF ACTIVIT Y SPECIFICATIONS}

Spec. No.

Title

1. Primary Sodium Disposal

2. Secondary Sodium Disposal

3. Disposal of Irradiated Fuel

4. Disposal of Unirradiated Fuel

5. Reaction of Residual Primary Sodium and Retirement of Primary Sodium System

6. Reaction of Residual Secondary Sodium and Retirement of Secondary Sodium System

7. Disposal of Contaminated and Irradiated Material

8. Reactor Isolation

9. Retirement of Auxiliary Systems

10. Securing of Is olation Structure

11. Retirement of Radioactive Waste Facility

12. Final Closeout of the Facility 


\section{LIST OF RETIREMENT DETAILED PROCEDURES}

Proc.

No.

1-1 Isolation of the Primary Fill Tanks

1-2 Removal of Primary Sodium Fill Tanks and Transfer to Railroad Cars

2-1 Isolation of the Secondary Sodium Fill Tanks

2-2 Removal of Secondary Sodium Fill Tanks and Transfer to Railroad Cars

3-1 Disposal of Irradiated Fuel

3-2 Loading of the Six-Element Irradiated Fuel Shipping Cask at the HNPF

4-1 Disposal of Unirradiated Fuel

5-1 Isolation of Primary Sodium Service System and Disassembly of the System

5-2 Removal of the Primary Sodium Block and Throttle Valves and Isolation of the Reactor from Its Related Sodium Systems

5-3 Isolate Intermediate Heat Exchanger Modules from Their Related Primary System

5-4 Isolation and Removal of Primary Pump Balancing Legs

5-5 Reaction of Residual Sodium in Reactor

5-6 Reaction of Residual Sodium in the Primary Heat Transfer Loops

5-7 Isolation and Removal of Primary Pump Cases

6-1 Isolation of the Secondary Sodium Service System and Disassembly of the System

6-2 Isolate the Intermediate Heat Exchangers from Their Related Secondary Systems

6-3 Isolate and Remove the Secondary Pump Cases from Their Related Systems

6-4 Isolation of Steam Generator Evaporators and Superheaters from Secondary Sodium Systems

6-5 Removal of Secondary Heat Transfer Piping and Components

6-6 Disassembly and Removal of Steam Generators

8-1 Final Closure of Reactor and Containment Vessel Pipes

8-2 Final Closure of Reactor Top Shield and Reactor Structure Pipe Hangers

9-1 Dismantling and Removal of Feedwater and Steam System Piping and Components 
$$
\text { . }
$$ 


\section{APPENDIX B \\ ACTIVITY SPECIFICATION NO. 5 - REACTION OF RESIDUAL PRIMARY SODIUM AND RETIREMENT OF \\ PRIMARY SODIUM SYSTEM}

AI-AEC-MEMO-12736 
$$
\text { . }
$$ 


\section{PURPOSE}

The purpose of this activity specification is to provide for reaction or removal of residual sodium remaining in the primary sodium system and to provide for disposal of primary sodium system hardware and components.

\section{ACTIVITY PLAN}

For purposes of this activity specification, the primary sodium system will include the primary sodium main heat transfer system, the reactor vessel, and the primary sodium service system.

Sodium has been drained from the primary sodium system into primary fill tanks. The sodium fllled primary fill tanks will be disposed of as per Activity Specification No. 1, "Primary Sodium Disposal." Residual sodium remains in certain portions of the system. Primary sodium system components and hardware will be classified in categories and disposed of accordingly. Component category classifications refer basically to the ultimate methods of disposal of the component. These category classifications are contained in Fart II, C3, of the HNPF Retirement Plan and are summarized below:

Category A - Property authorized by $\mathrm{CH}$ for shipment off site except as scrap. Such property will be removed from its present location and shipped off site to AEC designated recipients.

Category B - Property which will be removed from its present location and shipped off site as scrap.

Category C - Property which will remain in its present location at the HNPF.

Category D - Property which will be removed from its present location and placed in adequately contained subsurface volumes.

Category E - Property which will remain in its present location but whose ownership will be transferred to CPPD.

Category F - Property which must be removed to accomplish the retirement of the HNPF and which $\mathrm{CH}$ authorizes to be removed from its present location pending determination of its ultimate disposition. Such property will be provided with suitable protection against damage and temporarily stored until its final status as Category $A, B$, or $D$ material is decided.

The reactor vessel will be steam cleaned in place as described in Section IV and Appendix I of this activity specification. Other primary system components and hardware will be disposed of as follows:

Category $A$ and $F$ items will be removed from the system, residual sodium present will be removed and/or reacted as necessary, and prior to ultimate disposal the item will be sealed containing an inert atmosphere if necessary. Category $B$ items will be removed from the system and residual sodium present removed or reacted as necessary. Residual sodium in Category $C$ items will be reduced by reaction and/or physical removal to the specified limits for its safe containment. Where alternatives are stated, the steps employed shall be the most economical of those determined to be technically feasible. 


\section{ENGINEERING}

A. Engineering, Scheduling, and Requirements

Operations connected with this activity will be scheduled in coordination with other HNPF Retirement activities. However, work contemplated under this activity is largely independent of other activities.

The methods of reaction of residual primary sodium and retirement of the primary sodium system were chosen as a result of system engineering analysis of the problems involved.

Major subcontractual work items, engineering studies, and equipment design and procurement to be conducted in support of this activity are listed below:

1. Design, procurement, and installation of sodium pumping apparatus for removing the residual sodium heel remaining in the reactor vessel.

2. Detailed design, equipment procurement, and system modifications to permit the inplace steam cleaning of the reactor vessel.

3. Detailed design, equipment procurement, and system modifications to permit the inplace reaction and/or removal of residual sodium in primary system components, other than the reactor vessel, as necessary (e.g. , primary main heat transfer system piping).

4. Subcontractual work in connection with design, equipment procural, and existing hardware and structures modifications to permit the removal and/or reaction of residual sodium in Category $A, B$, and $F$ items. It is recommened, based on engineering feasibility and economic considerations, that auxiliary sodium cleaning facilities be provided. The pump wash cell will be used for sodium cleaning operations which can be economically and reliably performed by remote controlled steam cleaning. Auxiliary facilities will be required for the majority of sodium cleaning operations (e.g., manual removal, swabbing, water flush, heated oil bath, and manual steam cleaning).

5. Heavy equipment removal subcontracts for such removal as is deemed necessary.

6. Miscellaneous engineering studies, design, and equipment procural in support of this activity.

B. Health and Safety

This activity will be carried out under normal HNPF and CPPD Safety regulations. Radiological safety will be in accord with the HNPF Operations Manual Volume Ia, Part III, and 10CFR20 regulations. Hardware lifting and moving will be conducted in accord with the CPPD Safety Manual.

C. Standards

Welding procedures, welding qualifications, and inspection for welding of all components utilized for reaction fluid containment during in-place steam cleaning operations shall conform to the ASME Boiler and Pressure Vessel Code, Section VIII.

Care will be exercised to minimize damage to Category A and $F$ components during removal, handling, and cleaning operations. Category $B$ and $C$ components are scrap items and require no special handling to preserve the equipment.

Criteria for sodium removal and cleaning operations are contained in Part IV and Appendix I of this activity specification. 
Sodium pumping apparatus shall be procured and utilized to pump the residual sodium heel from the reactor vessel. The depth of the residual sodium heel will be measured before and after pumping.

Primary sodium fill tanks will be removed and the primary sodium service system will be modified in accord with Activity Specification No. 1, "Primary Sodium Disposal."

Each component for which an approved $\mathrm{CH}$ purchase order has been received will be disposed of in accord with its respective removal requirement.

It should be noted that category designations, as described in Section II of this activity specification, define the ultimate disposal of the item.

A. Main Heat Transfer System

1. The residual sodium heel in the reactor vessel will be pumped out to reduce the quantity of residual sodium to a minimum. The average depth of the sodium heel after pumping shall be approximately $1 / 4$-inch or less in depth.

2. The reactor vessel will be isolated from the primary system and steaming lines and hardware installed as described in Appendix I.

3. The primary balancing legs will be removed from the system and disposed of as Category $\mathrm{C}$ items.

4. The IHX units will be isolated and sealed by cutting and capping all primary sodium lines leading to the IHX units inside the IHX cells. Cutting and capping will be accomplished so that an inert atmosphere is maintained within the IHX. Secondary sodium lines will be cut and capped as per Activity Specification No. 6. Ultimate disposal of the IHX units will be as Category $A$ items.

5. The primary main heat transfer system 14-and 16-inch piping will be modified to permit in-place steaming reaction of residual sodium. The modification essentially consists of providing steam inlet lines from the steam mixing tank (to be utilized in reactor vessel steaming) and exhaust lines to the condenser (to be utilized in reactor vessel steaming), isolating the main loops from the Na service system by cutting and capping and installing a bypass line to replace the flow path formerly provided by the IHX units. The primary pumps have already been removed from the system. The primary pump cases will be modified to permit in-place steam cleaning of the 14-and 16-inch main piping. Sodium piping of lesser diameter $\left(6^{\prime \prime}, 4 ", 3 "\right.$, and $\left.2^{\prime \prime}\right)$ that is not utilized for steaming activities will be removed from the primary pipe galleries and ultimately disposed of as Category $B$ items.

6. The primary pumps, pump cases, and associated instrumentation and hardware will ultimately be disposed of as Category A items.

7. After modifications are complete the main primary piping (14-and 16-inch) will be steam cleaned in place one loop at a time utilizing essentially the same procedure as that to be employed in steaming the reactor vessel (Appendix 1). The primary pump cases will ultimately be removed from the system and the 14-and 16-inch piping will be sealed with a dry nitrogen atmosphere and disposed of as Category $C$ (left in place). 
8. The reactor vessel will then be steamed as described in Appendix I.

B. Primary Sodium Service System

1. Primary sodium service system hardware, components, and piping for which approved $\mathrm{CH}$ purchase orders are not received will be classified as Category $\mathrm{B}$ items and will be removed from the system with the following exceptions:

a) Pipe sections which extend through vault walls and which are difficult to remove will be classified as Category $\mathrm{C}$ and left in place. Residual sodium present will be removed and/or reacted in the most expeditious and economic manner.

b) Piping which contains relatively insignificant amounts of sodium will be classified as Category $C$ items and left in place or stored nearby in accord with operational convenience and economic considerations. For purposes of determining whether residual sodium is present in "significant" quantities the following procedure will be followed:

1) The piping will be cut into convenient lengths so that internal surfaces may be visually inspected.

2) If sodium is not present in layers exceeding $1 / 8$-inch in thickness, the piping will be classified as Category $C$. Sodium layers of $1 / 8$-inch or less will react with moisture from the atmosphere within approximately 30 days. This procedure will be followed provided that the radioactivity of the residual sodium present does not present a problem from the contamination control standpoint. If contamination control presents a problem, then the piping will be removed and disposed of as Category $B$ material (with residual sodium being removed and/or reacted as necessary).

2. Residual sodium in the below-grade Category B primary sodium system items will be removed and/or reacted as necessary utilizing the pump wash cell and/or auxiliary cleaning facilities. If residual sodium removal in a Category $B$ item is technically or economically unfeasible, the item will be suitably sealed and/or packaged and shipped off site for disposal elsewhere. 
APPENDIX I

(of Appendix B)

Reaction of Residual Sodium in the Reactor Vessel

Residual sodium in the Hallam Nuclear Power Facility reactor vessel will be reacted with a nitrogen-steam mixture, Significant considerations are summarized below under two headings:

A. System Modifications and Preliminary Tasks and, B. Process Control and Instrumentation.

A. System Modifications and Preliminary Tasks

1. The residual sodium heel in the reactor vessel will be pumped out to reduce the quantity of residual sodium in the reactor vessel to a minimum. The average depth of the sodium heel after pumping shall be approximately $1 / 4-$ inch or less in depth.

2. The reactor vessel will be isolated from the main heat transfer system bycutting and capping the following lines on the primary pipeway side of the gallery seals:

$\begin{array}{ccll}\text { Quantity } & \text { Size } & \text { Material Type } & \text { Remarks } \\ 3 & 14^{\prime \prime} & 304 & \text { Na inlet } \\ 3 & 16^{\prime \prime} & 304 & \text { Na outlet } \\ 1 & 6^{\prime \prime} & 304 & \text { Moderator coolant inlet } \\ 3 & 3^{\prime \prime} & 304 & \text { One fill and drain and } \\ 3 & 18^{\prime \prime} & \text { Carbon Steel } & \text { Guard pipe } \\ 3 & 20^{\prime \prime} & \text { Carbon Steel } & \text { Guard pipe } \\ 1 & 10^{\prime \prime} & \text { Carbon Steel } & \text { Guard pipe } \\ 1 & 6^{\prime \prime} & \text { Carbon Steel } & \text { Guard pipe for fill and drain }\end{array}$

3. A steam-nitrogen mixing station to introduce the reaction fluid into the reactor vessel and exhaust lines and a condensation tank to exhaust reaction products to the reactor building stack will be designed and installed.

4. A central control and instrumentation panel will be designed and installed for monitoring and control of the process.

B. Process Control and Instrumentation

1. General Description of Process

a. The reactor vessel and associated piping will be preheated to $250^{\circ}-300^{\circ}$ utilizing existing procedures and equipment and heated nitrogen flow.

b. Nitrogen-steam mixtures at $250^{\circ}-300^{\circ} \mathrm{F}$. will be introduced into the systems for reaction purposes. The initial steam/nitrogen ratio will be zero (i.e., pure heated nitrogen will be introduced into the system). The steam to nitrogen ratio will be slowly increased and the following parameters monitored.

(1) Oxygen content

(2) Hydrogen content

(3) Pressure

(4) Selected reactor vessel temperatures 
(5) Pressure

(6) Vessel effluent temperature

(7) Flow rates (both inlet and exit)

Instrumentation will be provided so that mass flows in and out of the reactor vessel may be estimated on the basis of recorded data.

c. Steam flow rates, steam-nitrogen percentages, and reaction times to be utilized will be specified in the Detailed Procedures. These operational criteria will be based on experimental studies of the process conducted by Atomics International.

2. Normal Operating Conditions

Tentative values for the normal conditions under which the steaming process will be operated are listed below. These values are based on the studies of the process conducted by Atomics International. The Detailed Procedures will contain more definitive data for the process as necessary.

a. Reactor vessel pressure, 1 to 6 psig.

b. Reactor vessel atmosphere temperature, $250^{\circ}-450^{\circ} \mathrm{F}$.

c. Reactor vessel structure temperature (bottom of vessel) $250^{\circ}-550^{\circ} \mathrm{F}$.

d. Oxygen content of reactor vessel, trace quantities only.

e. Nitrogen and steam mixture input to reactor vessel. $250^{\circ}-300^{\circ} \mathrm{F}$.

3. Tentative Maximum and Minimum Values

a. Maximum deliberate reactor vessel operating pressure to be utilized for steaming operations, 10 psig

b. Maximum reactor vessel pressure for flushing and venting operations (normal or emergency), 15 psig

c. Maximum reactor vessel oxygen content, $1 / 2 \%$

d. Maximum vessel structure temperature (TC's on bottom of reactor vessel), $650^{\circ} \mathrm{F}$

e. Minimum temperature of reactor vessel structure, $240^{\circ} \mathrm{F}$

f. Maximum reactor vessel atmosphere temperature, $600^{\circ} \mathrm{F}$

g. Minimum reactor vessel pressure, $1 / 2 \mathrm{psig}$

The above maximums and minimums are to a greater or lesser extent arbitrary but are currently considered to be reasonable operational values based on studies conducted to date. The above parameters will be more precisely defined as necessary in the Detailed Procedures. It is assumed that the operator will take corrective action when significant deviations from normal values are observed before the above values are reached. Routine operation somewhat outside the above limits is not necessarily hazardous and may be permitted provided there is an operational reason for such procedures and appropriate approval is granted.

However, in no event will steaming operations be continued if $2 \%$ or greater oxygen concentrations are present since such oxygen concentrations would very likely indicate a gross malfunction of the system. Pressures in excess of 25 psig are considered to be possibly damaging to the reactor bellows (rupture of the bellows does not present a hazard 
to personnel but would present other problems). Prolonged vessel atmosphere and structural temperatures in excess of $700^{\circ} \mathrm{F}$. are considered to represent an excessively fast rate of $\mathrm{Na-steam}$ reaction due to the use of an unreasonably high steam flow rate and/or steam/nitrogen ratio for the amount of sodium present. Reactor temperature should be maintained at $240^{\circ} \mathrm{F}$. or above to avoid any hazards due to possible steam condensation within the reactor vessel. Reactor pressure should be maintained at greater than atmospheric to preclude the possibility of air inleakage to the system.

4. Alarms

Tentative alarms and their setpoints are listed below. As discussed in Item 3 above, the setpoints are to a greater or lesser extent arbitrary and final values and/or additional alarms will be contained in the Detailed Procedures.

a. High oxygen content in reactor vessel, $1 / 2 \%$

b. High reactor vessel pressure, 2 psig above desired operating pressure

c. High reactor vessel atmosphere temperature, $550^{\circ} \mathrm{F}$

d. High reactor vessel structural temperature, $650^{\circ} \mathrm{F}$

e. Low reactor vessel structural temperature, $240^{\circ} \mathrm{F}$

f. Low reactor vessel pressure, $1 / 2 \mathrm{psig}$

g. Automatic action high pressure alarm (4 psig above desired operating pressure)

h. High radiation effluent alarm.

All alarms shall give both visible and audible alarm signals at the central control and instrumentation panel.

5. Operator Action in Case of Alarm

Detailed operator actions in case of alarm will be contained in the Detailed Procedures. The general nature of operator action in case of alarm is briefly summarized below.

Upon high vessel oxygen content alarm the operator shall cut off steam flow and commence nitrogen flushing operations until oxygen content returns to normal values.

Upon high reactor vessel pressure alarm, high reactor vessel atmosphere temperature alarm, and high reactor vessel structural temperature alarm the operator shall reduce sieam and total flow rate as necessary to return conditions to normal. The automatic action high pressure alarm will automatically shut off both the steam and nitrogen supplies to the reactor vessel.

Upon low reactor vessel temperature alarm the operator shall energize the reactor vessel heaters as necessary to return conditions to normal.

Upon low reactor vessel pressure alarm the operator shall increase nitrogen flow rate as necessary to return conditions to normal.

Upon high radiation effluent alarm the operator shall begin to reduce steam and nitrogen flow rate preparatory to shutting down steaming operations and an investigation will be immediately initiated as to the cause of the alarm. Release of quantitites of radioactive material sufficient to cause a high radiation effluent alarm is considered to be an extremely unlikely occurrence, and instrument malfunction and/or operations elsewhere in the plant 
are considered to be more likely causes of the alarm. If investigation indicates the alarm is valid, the steaming process shall be shut down.

The occurrence of a valid high oxygen alarm, high radiation effluent alarm, or a significant sodium reaction pressure transient requires that, after immediate operator action is taken, the steaming operation will be shut down and an investigation of the causes of such occurrences will be conducted. Steaming operations may be recommenced after the observed phenomena have been explained, damage (if any) has been assessed, adequate provision made for prevention of future re-occurrence, and appropriate approval (to be specified in the Detailed Procedures) is obtained.

6. Reaction Completion

The reaction steaming process shall be performed in a manner such that there is a high degree of assurance, on the basis of studies conducted by Atomics International, that the reaction of residual sodium will be essentially complete. That is, reaction times utilized for specified steam percentages and flow rates shall be conservative in regard to the actual reaction times experimentally recorded to essentially completely react the estimated thicknesses of residual sodium present. These minimum reaction times, along with pertinent other data, will be specified in the Detailed Procedures. After the minimum reaction run times have been carried out, an additional requirement is that hydrogen evolution must be shown to be essentially neglibible over a prolonged period (e.g., 6 hours) prior to the cessation of steaming operations. Finally, sodium samples of various thicknesses shall be placed in the reactor vessel prior to steaming operations and removed after the above requirements are met. Thus, a direct experimental check upon the efficacy of the steaming operations will be available.

After steaming operations have been completed, the steam supply will be cut off, the reactor vessel heaters will be energized as necessary, and heated nitrogen will be passed through the vessel to dry the $\mathrm{NaOH}$ which was formed during steaming. This will insure that the $\mathrm{NaOH}$ remaining in the vessel will be in solid form when the reactor is cooled to ambient temperature. Finally, the reactor vessel will be sealed with a dry nitrogen atmosphere such that a small positive gage pressure will be present under ambient conditions. The drying and nitrogen atmosphere sealing operation reduces dry corrosion rates to neglibible proportions. 


\begin{abstract}
APPENDIX C
RETIREMENT DETAILED PROCEDURE 5-5

REACTION OF RESIDUAL SODIUM IN REACTOR
\end{abstract}

AI-AEC-MEMO- 12736

103 
$$
\text { . }
$$ 


\section{PURPOSE}

This procedure establishes a step by step sequence for ope rating the steam-nitrogen process system for chemically reacting the residual sodium in the reactor vessel and its connecting line stubs.

\section{DESCRIPTION}

The activities to be accomplished by this procedure are as follows:

Establish specified pre-operating conditions on the steam-nitrogen system, the reactor vessel and the reactor vent system as designated by Section IV of this procedure. Admit the specified steam-nitrogen mixtures into the reactor vessel through the reactor line stubs as.designated by Section IV of this procedure, determine that the residual sodium in the reactor has been chemically reacted as per specified tests of the gaseous effluent from the reactor and by inspection of the incore sodium samples, terminate the steaming operation, purge inert gas through the system complex to insure that the moisture is removed, terminate the operation and permit the system, including the reactor, to cool to ambient temperature.

\section{CRIT ERIA}

\section{A. Requirements and Prerequisites}

1. This activity will be co-ordinated with othe $r$ plant activities during the HNPF retirement program.

2. The reactor cavity atmosphere shall have $<2-1 / 2 \% \mathrm{O}_{2}$.

3. The steam-nitrogen system shall have been thoroughly tested, instruments calibrated and system operated to designed operating requirements per detailed procedure prior to initiating the operation detailed in Section IV of this procedure.

4. Sodium samples will be installed per Section VI of this procedure.

5. Drain tanks $T-2,3$ and 5 will have a water heel deep enough to cover the end of the drain.

6. Pressures, temperatures, flow, composition of the steam-nitrogen mixture into the reactor vessel shall be recorded at 30 minute intervals during the initial reaction period (four hours); thereafter, this data shall be recorded at one-hour intervals.

7. Those personnel assigned to perform the work detailed in Section IV of this procedure shall be thoroughly checked out on all aspects of the operation. This requirement will include physically operating the system per detailed procedure prior to admitting process gases (steam-nitrogen) into the reactor.

B. Health and Safety

1. Special work permits are required for the work detailed in Section IV of this procedure.

2. A minimum of two operators shall be in attendance in the reactor building during the period that the steam-nitrogen system is in operation. A third operator will be required as necessary to record data in the control room.

3. Only authorized personnel will be permitted access to the primary pipe gallery during the steaming operation. 
4. Personnel will wear protective clothing and equipment as deemed necessary by CPPD Health and Safety.

5. Activities that do not pertain to the sodium reaction operation will be conducted only by special CPPD Health and Safety permission on or near the reactor loading face or the sodium reaction process system exposed in the high bay area.

C. Standards

Work performed in connection with this activity will be carried out under normal HNPF Health and Safety regulations and in accordance with the specified requirements of this procedure.

IV METHOD OF ACCOMPLISHMENT AND SEQUENCE OF EVENTS (Refer to Dwg. N69012001, C Change)

1. All preparatory work shall be completed before starting the work of this section. Verify that $V-5$ is tagged open and the caps removed from the drains between V-15-15A, V-55$55 \mathrm{~A}$ and $\mathrm{V}-57-57 \mathrm{~A}$.

2. Confirm that the $\mathrm{LN}_{2}$ storage tank is full and the back-up $\mathrm{N}_{2}$ supply is available and connected and the $\mathrm{N}_{2}$ system is in normal operation with $\mathrm{V}-912$ and $\mathrm{V}-46$ open.

3. The reactor cover gas will be supplied at $1 / 2$ psig through PCV-3 as indicated on PI-3 with V-51, V-52 block-reactor $\mathrm{N}_{2}$ supply, and V-41 block-line 148-3-AA reactor drain line open. $V-31,67,68$ and 69 block valve to PI-2, 3, 4, and PRC-1 open, with the following valves closed:

$$
\begin{aligned}
& V-1,2,3,4,6,7,11,12,15,15 A, 17,18,19,24,25,26,27,28,29,30, \\
& 33,36,42,43,44,45,47,53,54,55,55 A, 57,57 A, 58,59,60,63,65,66
\end{aligned}
$$

4. Energize the preheat on the gas mixing tank and all associated lines to and from the reactor. Check the preheat temperature on the instruments assigned and verify that the reactor and mixing tank temperature are $250^{\circ}-350^{\circ} \mathrm{F}$. See date sheet IV -1 .

5. Open V-58 and V-60 condenser cooling water and adjust flow on FI-608 to 140 gpm. Vent shell side by opening $V-59$ as required to remove any trapped gas in the condenser shell.

Initial Purge of System

6. Open the following valves:

V-63 throttle condenser gas outlet

V-33 inlet-hydrogen analyzer

V-17 block-reactor bypass

V-2 block $\mathrm{N}_{2}$ supply

Verify that $S V-3 \mathrm{~V}$ is open and reactor pressure is above $1 / 4$ psig. Verify $\mathrm{N}_{2}$ system in normal operation ( $\mathrm{LN}_{2}$ system operating with 50 psig in the low pressure storage tank T-901), and energize $\mathrm{N}_{2}$ heater $\mathrm{H}-2$ with temperature control set at $150^{\circ} \mathrm{F}$.

7. Open V-65, block $\mathrm{N}_{2}$ sample to $\mathrm{O}_{2}$ analyzer, and check out operation of $\mathrm{O}_{2}$ analyzer. Verify $\mathrm{N}_{2}$ supply $<1 / 2 \% \mathrm{O}_{2}$.

8. Check SV-2V open, Open V-7, and establish $20 \mathrm{cfm}$ flow as read on FI-2. Compare FI-2 with FI-900. Throttle V-63 to maintain 1 psig minimum on PI-4. 
9. Energize $\mathrm{N}_{2}$ heater $\mathrm{H}-1$ with temperature on $\mathrm{T} 1 \mathrm{C}-1$ set at $325^{\circ} \mathrm{F}$.

10. Observe temperature on TRC-1 and pressure on PRC-1. Record all data on Data Stitet IV-1. TIC-1 should not drop below $250^{\circ} \mathrm{F}$.

11. Observe $\mathrm{O}_{2}$ analyzer and purge until $\mathrm{O}_{2}$ is $<1 / 2 \%$.

12. Increase nitrogen flow on $F I-2$ to $150 \mathrm{cfm}$ in $40 \mathrm{cfm}$ increments using $V-6$ and $\dot{V}=\overrightarrow{7}$. Record all pressures and temperatures on Data Sheet IV-1. Àjjust $\ddot{V}-63$ as réquired tó maintain 1 psig minimum back pressure on PI-4 at all times.

13. Close V-6, V-7, and V-63. Install caps on the drains between $V-15-15 A$ and $V-57-57 A$.

14. Close V-17 block-reactor bypass and open V-15 and V-15A block-reactor inlet header.

15. Open V-57 and V-57 A block-reactor effluent outlet. Adjust V-6 and V-7 to establish $20 \mathrm{cfm}$ flow through line 148, reactor fill and drain, as read on FI-2, Adjust V-63 to maintain 1 psig minimum on $\mathrm{PI}-4$. Observe the $\mathrm{O}_{2}$ analyzer; oxygen should remain below 1\%. Temperature on TRC-1 should not go below $250^{\circ} \mathrm{F}$. Record data on Data Sheet IV -1 .

16. Increase $\mathrm{N}_{2}$ flow to $150 \mathrm{cfm}$ on $\mathrm{FI}-2$ in $40 \mathrm{cfm}$ increments using $\mathrm{V}-6$ and $\mathrm{V}-7$. Adjust $\mathrm{V}-63$ to maintain 1 psig minimum on PRC-1. Record data on Data Sheet IV -1 .

17. Purge the inlet and outlet headers by alternately opening and closing the following valves. Purge each combination for the indicated time. Observe that the $\mathrm{O}_{2}$ analyzer remains $<1 / 2 \%$ oxygen.

\begin{tabular}{|c|c|c|}
\hline Open & Close & Purge Time \\
\hline$V-45$ & $V-41$ & 1 Min. \\
\hline$V-44$ & V-45 & $10 \mathrm{Min}$. \\
\hline$V-28$ & $V-44$ & $1 \mathrm{Min}$. \\
\hline$V-27$ & $V-28$ & $10 \mathrm{Min}$. \\
\hline$V-26$ & $v-27$ & $10 \mathrm{Min}$. \\
\hline$V-25$ & $v-26$ & $10 \mathrm{Min}$. \\
\hline$V-24$ & $V-25$ & $5 \mathrm{Min}$. \\
\hline$V-43$ & $V-24$ & $5 \mathrm{Min}$. \\
\hline$V-42$ & $v-43$ & $5 \mathrm{Min}$. \\
\hline
\end{tabular}

18. Open $V-41$, close $V-42$, close $V-6$ and $V-7$ and reduce $N_{2}$ flow on FI-2 to zero. Close $\mathrm{V}-63$. Turn off the $\mathrm{N}_{2}$ heater $\mathrm{H}-1$.

19. Close V-15, V-15A, V-57 and V-57A. Remove the caps on the drains between the two pairs of valves.

20. Throttle V-5, open V-47, and warm up the steam header. Open V-1 block-steam supply V-11 mixing tank vent, and V-12 mixing tank drain. Crack open V-4 and warm up the steam header and mixing tank, limit pressure on PI-2 to 10 psig maximum and flow on FI-1 to $20 \mathrm{cfm}$ maximum. Open V-66 and blow down FI-1, close V-66 and V-5.

21. Open V-29 block inlet laundry room hold-up tanks. Determine that V-1188 or V-1197 inlet to No. 1 or No. 2 hold-up tank is open.

22. Crack open $\mathrm{V}-7$ and establish to $10 \mathrm{cfm} \mathrm{N}$ flow on FI-2. Turn on $\mathrm{N}_{2}$ heater $\mathrm{H}-1$.

23. Open $V-17$ and then close $V-11$ and $V-12$ and adjust $V-63$ to hold 1 prig minimum on PI-4. Adjust $\mathrm{N}_{2}$ flow to $100 \mathrm{cfm}$ on FI-2 using V-6 and V-7. Adjust steam flow to $25 \mathrm{cfm}$ on FI-1 
using V-3 and V-4. Record all data on Data Sheetl IV-1, -2 . Determine that all systems are operating satisfactorily. Condensate flow should be observed in FI-5.

24. Verify that this procedure has been completed to step 23 and examine all data to determine if all conditions are satisfactory. Verify that item 5, Section III-A, "Requirements and Prerequisites," of this procedure has been completed and attach a signed-off training procedure. The system is now ready to begin steaming the reactor.

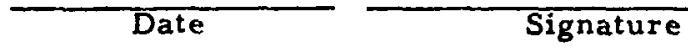

Based on previous test experience, the following general information should be used as a guide for determining if the steam-sodium reaction is controlled and for making process adjustments for unusual circumstances.

a. Reactor vessel gas temperature and pressure and the hydrogen evolution rate are the main data points which indicate the status of the reaction. The reaction is assumed to be controlled if the reactor vessel gas temperature and pressure remain relatively constant. However, if during steady-state operation reactor vessel gas temperature reaches $450^{\circ} \mathrm{F}$ or reactor vessel pressure reaches 6 psig, the steam flow should be immediately reduced in an attempt to correct the situation. When normal conditions are again established for a period of 30 minutes, the steam flow should be slowly returned to the operating point.

b. During periods of changing steam-nitrogen gas mixture ratios it is possible that the above-noted unusual temperature and pressure conditions may be encountered. If this is the case, the nitrogen flow should be increased or the steam flow reduced (depending upon which flow is beging adjusted) to the previous set point where essentially a steadystate condition existed. When conditions are again normal for a minimum of $30 \mathrm{~min}-$ utes, attempts should be made to continue with the procedure.

c. If at any time the reaction appears to be uncontrollable by simply reducing steam flow, the steam and nitrogen flow should be completely stopped and supervision notified immediately. Reactor cover gas will be maintained at 1/2 psig through PCV-3.

\section{Caution}

The following operating limits should not be exceeded:

PRC-1 Reactor pressure minimum $1 / 2 \mathrm{psig}$ maximum 6 psig

Reactor Vessel Atmosphere Effluent Temperature

TRC-1 Minimum $250^{\circ} \mathrm{F}$ Maximum $450^{\circ} \mathrm{F}$

Reactor Vessel (bottom) Temperature

Minimum $250^{\circ} \mathrm{F}$

Maximum $550^{\circ} \mathrm{F}$

Reactor cavity liner temperature maximum $225^{\circ} \mathrm{F}$.

Oxygen content of reactor effluent and nitrogen supply $<1 / 2 \%$.

In the event that any of these conditions are approached or exceeded, refer to Section $V$, "Operator Action in Case of Alarm." 
Steaming Reactor

25. Reduce steam flow to zero by closing $V-3$ and $V-4$ and crack open $V-12$ mixing tank drain. Nitrogen will bleed from the tank. Purge at $100 \mathrm{cfm} \mathrm{N}_{2}$ for 5 minutes to dry out the system.

26. Close $V-41$, crack V-45, and observe $\mathrm{N}_{2}$ flow into drain tank $\mathrm{T}-5$. Replace the caps on the drain between $\mathrm{V}-15-15 \mathrm{~A}, \mathrm{~V}-55-55 \mathrm{~A}$ and $\mathrm{V}-57-57 \mathrm{~A}$.

27. Open V-57 and V-57 A block-reactor effluent outlet. Open V-15 and V-15A block-reactor inlet header. Purge through V-45. Open 41 , close V-17 and V-45.

28. Establish $100 \mathrm{cfm} \mathrm{N}$ flow through the reactor. Adjust $\mathrm{V}-6$ and $\mathrm{V}-7$ as required. Adjust V-63 to hold 1 psig minimum back pressure on the reactor.

29. Crack open V-4 and slowly increase the steam flow on FI- 1 to $25 \mathrm{cfm}$. Blow down the mixing tank and close V-12 when dry steam appears. Monitor the hydrogen analyzer and observe for an increase in hydrogen. Record all data at 30 minute intervals. Watch carefully the temperature on TRC-1 and monitor reactor vessel temperature. Compare with data taken in step 23. An increase in loading face shield and upper cavity liner temperatures is expected until these surfaces approach the temperature of the steam going into the reactor. The reactor effluent temperature TRC-1 is not expected to be appreciably higher than the inlet temperatures on $T R-1$ and $T R-2$. Notify supervisor if $T R C-1$ goes above $350^{\circ} \mathrm{F}$. Temperatures will be limited to a maximum $450^{\circ} \mathrm{F}$ for normal operation.

30. After conditions have reached a quasi-steady condition, while holding steam flow constant at $25 \mathrm{cfm}$ reduce nitrogen flow from $100 \mathrm{cfm}$ to $60 \mathrm{cfm}$ in $20 \mathrm{cfm}$ increments waiting 10 minutes between changes. Increase steam flow from $25 \mathrm{cfm}$ to $60 \mathrm{cfm}$ in $17 \mathrm{cfm}$ increments waiting 10 minutes between changes. Continue at a steaming $\mathrm{rate}$ of $60 \mathrm{cfm} \mathrm{steam}$ $60 \mathrm{cfm}$ nitrogen, $50 \%$ mixture steam and nitrogen for 6 hours. Record all data at $30 \mathrm{~min}-$ ute intervals for 4 hours. Here after all data will be recorded at one-hour intervals.

31. Alternately increase nitrogen flow and then steam flow in $20 \mathrm{cfm}$ increments at $10 \mathrm{~min}-$ ute intervals until flow in increased to a total of $300 \mathrm{cfm}(150 \mathrm{cfm}$ nitrogen and $150 \mathrm{cfm}$ steam). Continue this steaming rate for at least 6 hours.

NOTE: The hydrogen detector will indicate at what rate the sodium-steam reaction is taking place. The hydrogen detector should be used as a guide for knowing when to proceed if the concentration of hydrogen is high enough to give a good indication on the detector.

32. Open V-44 and begin steaming 239-14-AA, close V-41. Steam for one hour or until the hydrogen detector shows a peak and then a decrease.

33. Open $V-28$ and blow down the header until dry steam is observed at the condensate drain into T-3 drain tank. TR-1 should read the same as TR-2 and not less than $250^{\circ} \mathrm{F}$. Close $\mathrm{V}-28$.

34. Open V-26 and introduce steam through line 237-14-AA. Throttle V-44 but leave enough flow to keep the line warm. Steam for one hour or until the hydrogen detector peaks and then shows a decrease.

35. Open V-27 and begin steaming line 238-14-AA, close V-26 and steam for one hour or until the hydrogen detector shows a peak and then a decrease. 
36. Open V-24 and begin steaming line 231-16-AA, close V-27. Steam for one hour or until the hydrogen detector shows a peak and then a decrease.

37. Open V-25 and begin steaming line 284-6AA, close V-24 and steam for one hour or until the hydrogen detector shows a peak and then a decrease.

38. Open V-42 and begin steaming line 232-16-AA, close V-25. Steam for one hour or until the hydrogen detector shows a peak and then a decrease.

39. Open V-43 and begin steaming line 233-16 AA, close V-42. Steam for one hour or until the hydrogen detector shows a peak and then a decrease.

40. Open $V-41,42,44,24,25,26$ and 27 . Introduce steam through all lines into the reactor. Reduce nitrogen flow from $150 \mathrm{cfm}$ to $60 \mathrm{cfm}$ in $20 \mathrm{cfm}$ increments waiting 10 minutes between changes. Increase steam from $150 \mathrm{cfm}$ to $240 \mathrm{cfm}$ in $20 \mathrm{cfm}$ increments waiting 10 minutes between changes. Continue under $80 \%$ steam concentration for 10 hours.

41. Close V-42,43,44,24, 25, 26 and 27. Steam through V-41 and line 148-3 for 1 hour.

42. Open V-44 and close V-41 and steam through line 239-14-AA for 1 hour.

43. Open $\mathrm{V}-28$ and blow down the header until dry steam is observed at $\mathrm{T}-3$ drain tank. Close $\mathrm{V}-28$.

44. Open V-26 and steam through line 237-14-AA for 1 hour. Throttle V-44 but leave enough flow to keep the line warm.

45. Open V-27, close V-26 and steam line 238-14-AA for 1 hour.

46. Open V-24 and close V-27. Steam line 231-16-AA for 1 hour.

47. Open V-25 and close V-24. Steam line 284-6-AA for 1 hour.

48. Open V-42 and close V-25. Steam line 232-16-AA for 1 hour.

49. Open V-43 and close V-42. Steam line 233-16-AA for 1 hour.

50. Open V-41,42,44,24, 25, 26 and 27. Monitor the hydrogen detector and continue steaming at $80 \%$ steam concentrations $(60 \mathrm{~cm} \mathrm{~N}, 240 \mathrm{cfm}$ steam) until hydrogen has been undetected for 6 hours.

51. Reduce the steam and nitrogen flow to zero by closing V-3, 4, 6 and 7 and turn off $N_{2}$ heater $\mathrm{H}-1$. Reactor pressure will be maintained at $1 / 2 \mathrm{psig}$ through PCV-3. Close $\mathrm{V}-63, \mathrm{~V}-47$, and $\mathrm{V}-1$. Tag open $\mathrm{V}-5$.

52. Remove one sodium sample from the reactor to determine if the sodium has all been reacted by the steam. If reaction of the first sample is not complete, repeat step 50. If the first sample is complete, remove the second sample to determine if it has been completely reacted. If both samples are done, proceed to the next step in this procedure. If the reaction is not complete on the second sample, repeat step 50. Repeat this process until examination of two samples indicates the reaction has been completed. All samples will be removed and handled according to Section VI of this procedure.

53. Prepare to purge the reactor. Set all preheat control points up to $450^{\circ} \mathrm{F}$. Reset TAH-1 to $450^{\circ} \mathrm{F}$. Close V-24, 42, and 43 .

54. Turn on heater $\mathrm{H}-1$, open $\mathrm{V}-6$ and $\mathrm{V}-7$ and purge the reactor with dry nitrogen holding nitrogen temperature outlet on both heaters as high as possible, not to exceed $450^{\circ} \mathrm{F}$ on 
$\mathrm{H}-1$ and $150^{\circ} \mathrm{F}$ on $\mathrm{H}-2$, at a flow rate of $80 \mathrm{cfm}$ minimum. Adjust $\mathrm{V}-63$ to hold $1 / 2 \mathrm{psig}$ back pressure on the reactor. Continue the purge for 24 hours.

55. Open V-24, 42 and 43. Continue the purge until the level control LC-1 has stopped collecting water.

56. Secure the purge by closing $V-6,7$ and 63. Reactor pressure will be maintained at $1 / 2$ psig through PCV-3. Secure nitrogen heaters $H-1$ and $H-2$.

57. Remove remaining sodium samples from the reactor according to Section VI of this procedure and verify that the samples are solid at room temperature.

58. Secure all reactor and reaction system heaters and allow the reactor to cool to ambient temperature. Maintain $1 / 2$ psig on the reactor through $P C V-3$ or use an alternate source of $\mathrm{N}_{2}$ supply if reaction system is disconnected from the reactor before the reactor reaches ambient temperature.

\section{CORRECTIVE ACTION IN CASE OF ALARM}

1. Reactor high pressure (alarm set at 8 psig, automatic action closes SV-IV and SV-2V at 10 psig; manual reset is required to reopen $S V-1$ and $S V-2)$. Open $V-63$, verify flow in FI- 4 and determine that total flow on FI-1 and FI-2 has not exceeded $300 \mathrm{cfm}$. Close V-3 and $V-4$, reduce steam flow as required to reduce pressure in the reactor. Determine that PCV -3 is operating satisfactorily.

2. Reactor low pressure (alarm set at $1 / 4$ psig). Automatic action closes SV-3V when alarm sounds. SV-3V opens when alarm clears. Check to see that PCV-3 is operating and PI-3 is indicating pressure. Throttle V-63 to increase reactor pressure to 1 psig as indicated on $\mathrm{PI}-3$.

3. High oxygen (alarm set at $1 / 2 \% \mathrm{O}_{2}$ in nitrogen). Determine that the reactor is above atmospheric pressure and that the nitrogen supply has not been contaminated with oxygen. A high alarm might be expected during initial purging operations. Only trace quantities of oxygen should be present during the steaming operation. If a high oxygen $>1 / 2 \%$ occurs during the steaming operation, secure the steam flow by closing V-3 and V-4 and continue the hot nitrogen purge until the trouble can be located and corrected.

4. Reactor atmospherc effluent high temperature (alarm set at $550^{\circ} \mathrm{F}$ ). Reduce the steam and nitrogen flow being careful to maintain the same steam-nitrogen flow ratio. This will reduce the reaction rate and effluent temperature should decrease.

5. Reactor atmosphere effluent low temperature (operating limit $250^{\circ} \mathrm{F}$ ). A low effluent temperature on TRC-1 indicates that something is wrong with the temperature of the steam and/or nitrogen supply. Determine that the steam supply is $350^{\circ} \mathrm{F}$ as read on $\mathrm{TI}-1$ and the nitrogen supply is $300^{\circ} \mathrm{F}$ or higher as read on TIC-1. Discontinue steaming if the temperature on TRC-1 goes below $225^{\circ} \mathrm{F}$ until the cause of the low ternperature can be determined and corrected.

6. Reactor vessel bottom low temperature. Alarm set at $250^{\circ} \mathrm{F}$ as read on $\mathrm{T} 1-21-26$ through 30 on main board in control room. Determine that reactor bottom heaters are on and operating. 


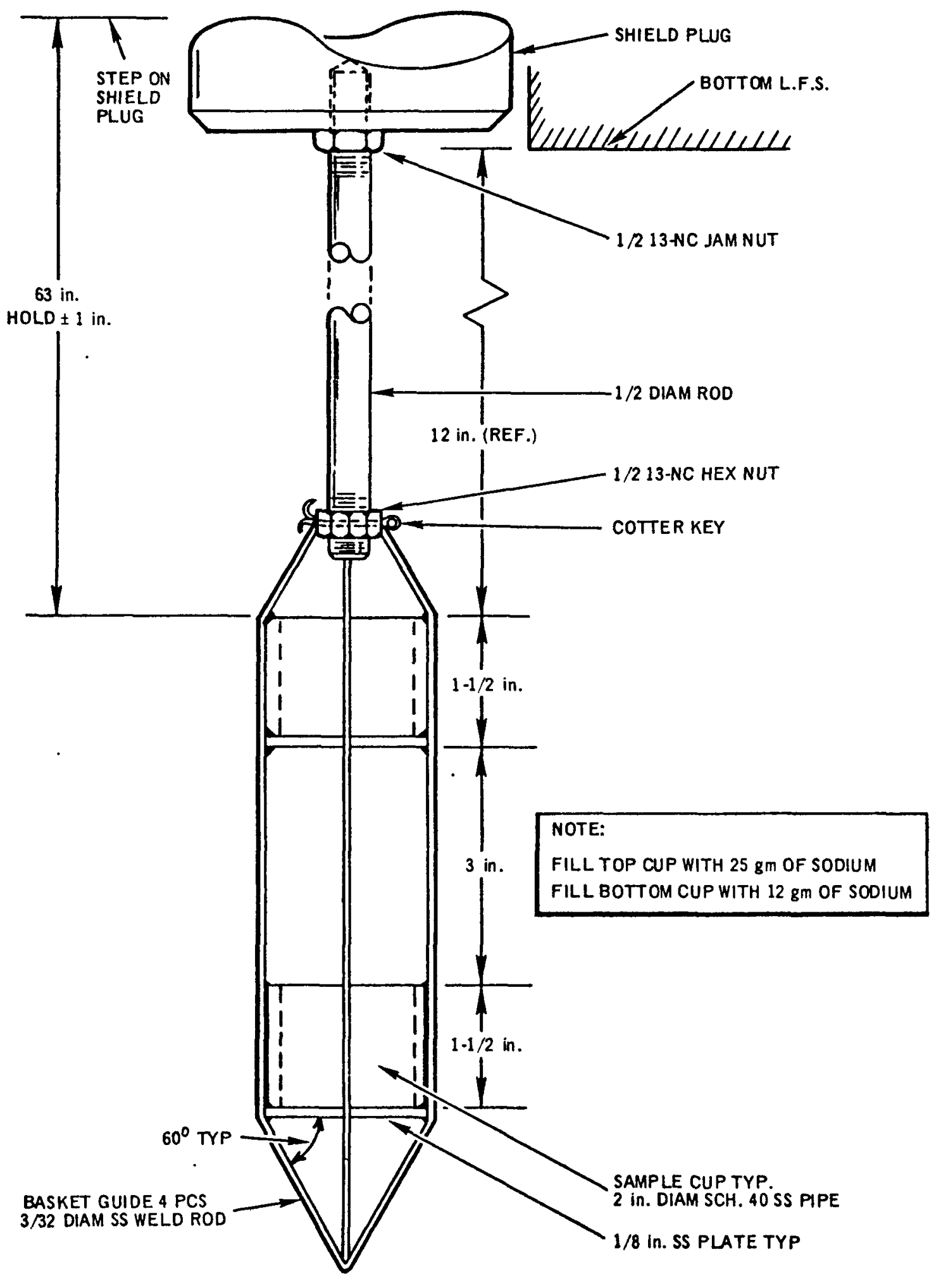

$7709-5401$

Figure 1. Sodium Sample Suspended from Shield Plug 
7. Reactor vessel bottom high temperature alarm set at $550^{\circ} \mathrm{F}$ as read on $\mathrm{TI}-21-26$ through 30. Determine that the bottom heaters are off. If necessary, reduce steam and nitrogen flow to slow the reaction rate and reduce reactor vessel bottom temperatures.

8. Reactor cavity liner and loading face shield temperatures. There is no alarm but the cavity liner and loading face shield temperature as read on TI-18 on the main board should be limited to a maximum of $225^{\circ} \mathrm{F}$.

VI. PREPARATION, INSTALLATION AND REMOVAL OF SODIUM SAMPLES USED TO DETERMINE COMPLETION OF THE REACTION PROCESS IN THE REACTOR

Each sample will consist of 2 cups, one suspended 3 inches above the other. The bottom cup will contain 12 grams of sodium; the upper cup will contain 25 grams. The sample cups will be fabricated from a section of 2 inch diameter schedule 40 stainless steel pipe $1-1 / 2$ inches long with a flat plate welded 1/4" deep on the bottom. The sample cup assembly will be suspended 1 foot below the loading face shield as shown in Figure 1.

Six samples will be installed in the reactor by attaching them to the bottom of a reactor shield plug and inserting them into the reactor using the short gas lock. A temporary operating procedure will be developed for this operation at the time the work is to be done. Sample locations are shown in Figure 2.

The samples will be removed, using the same procedure that covers the installation. The samples will be removed as required to monitor the reaction and drying process. 


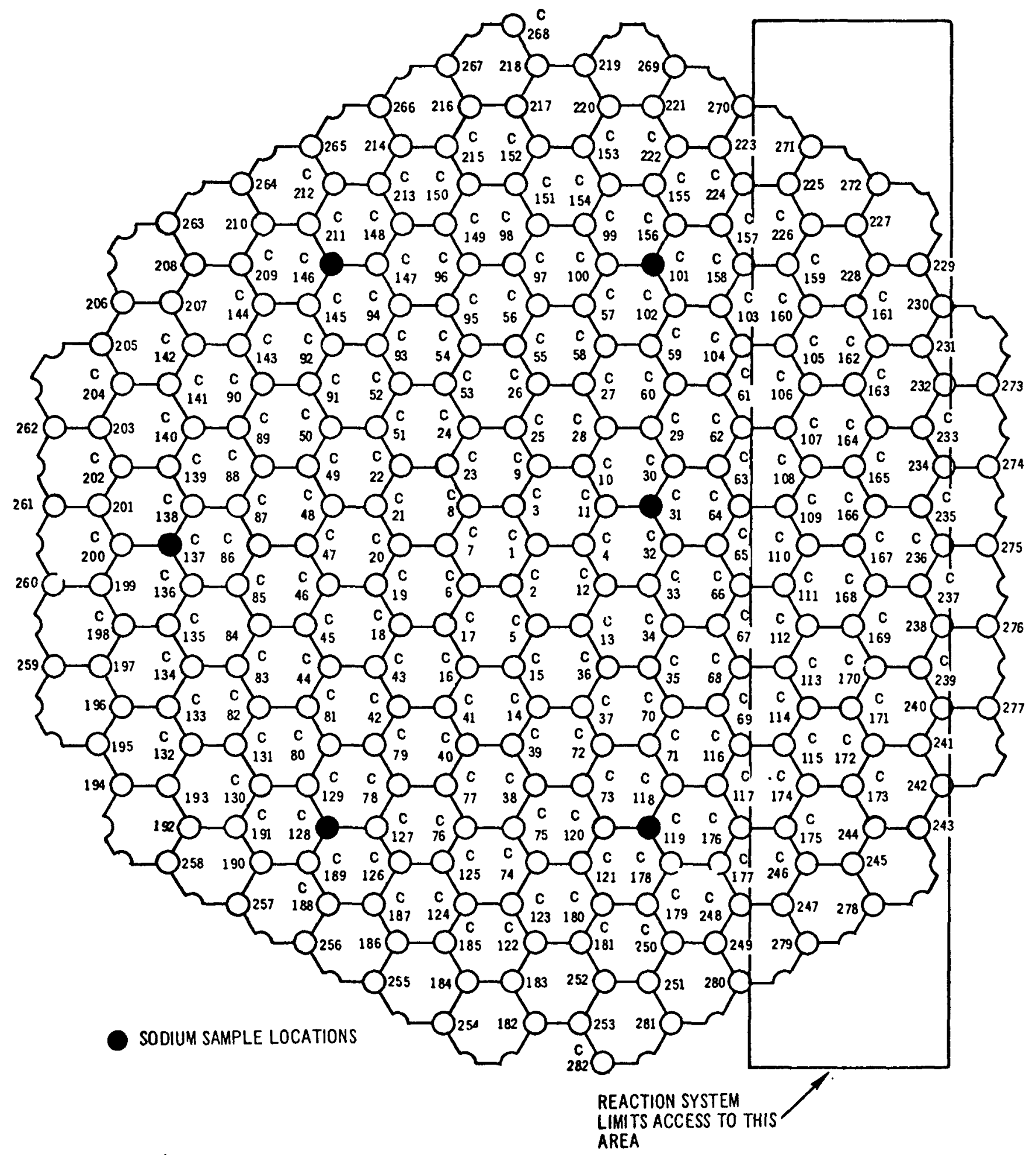

$7709-5402$

Figure 2. Sodium Sample Locations 


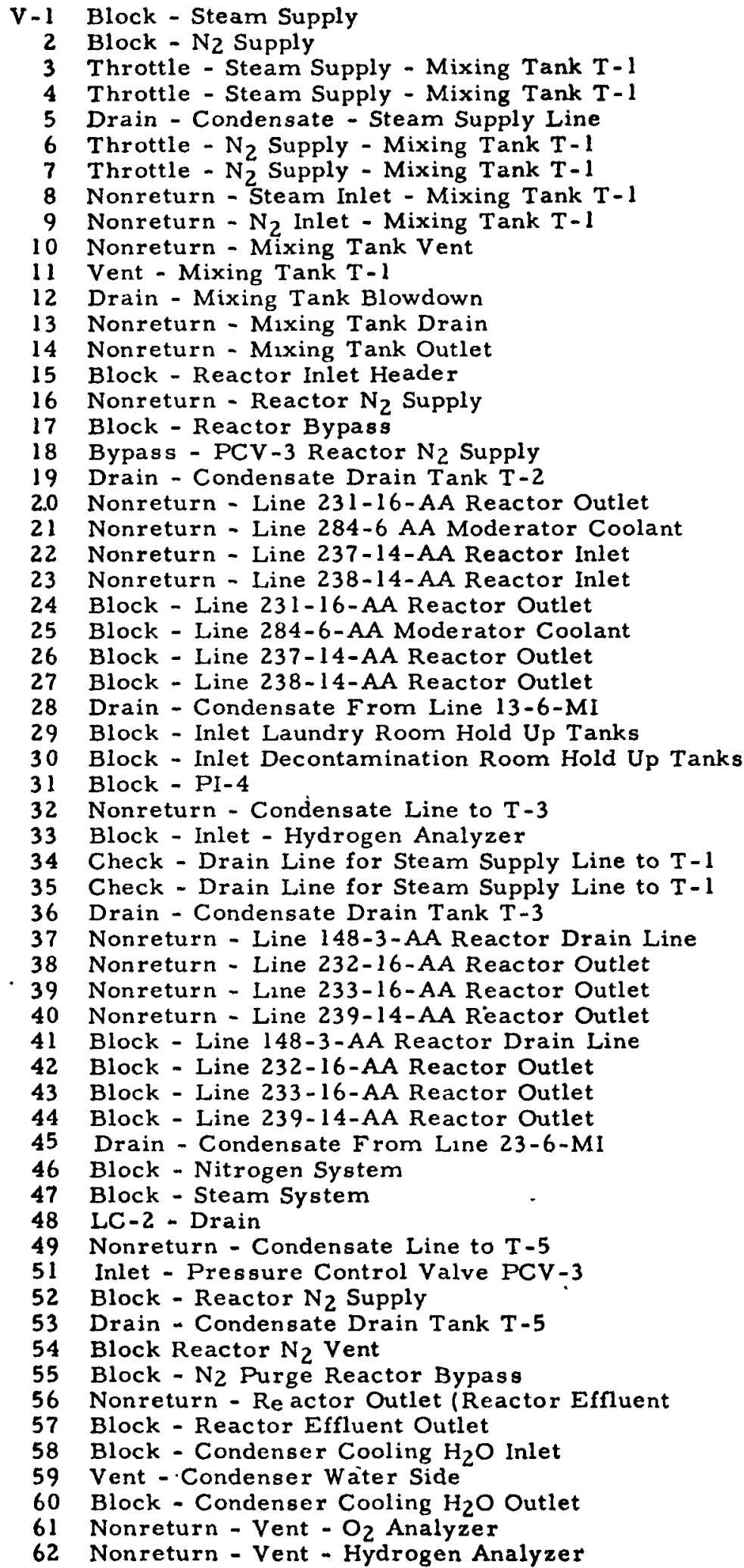


V-63 Throttle - Condenser - Gas Outlet

64 Nonreturn - Condenser - Gas Outlet

65 Block - $\mathrm{N}_{2}$ Sample to $\mathrm{O}_{2}$ Analyzer

66 Blowdown - FI-1 Steam Flowmeter

67 Block - PI-2

68 Block - PI-3

69 Block - PRC-1

70 Heater $\mathrm{H}-2$ Bypass

71 Heater H-2 Block

72 Heater H-2 Block

73 PCV-1 Block

74 PCV-1 Block

75 PCV - 1 Bypass

PCV-1 Nitrogen Supply from $\mathrm{GN}_{2}$ Trailer Set at 80 psig

$2 \quad \mathrm{~N}_{2}$ Sample to $\mathrm{O}_{2}$ Analyzer Set at $1 / 2 \%$

$3 \mathrm{~N}_{2}$ Cover Gass to Reactor Set at $1 / 2 \mathrm{psi}$

SV-1V Steam Supply High Pressure Reactor Cut Off

2V $\mathrm{N}_{2}$ Supply High Pressure Reactor Cut Off

3V Reactor Vent Low Pressure Cut Off

4V Control Valve Condenser Drain

PSV - 1 Relief Valve - Mixing Tank - Set at 25 psig

2 Relief Valve - $1 / 2 \mathrm{lb}$. Reactor Supply Set at 10 psig 


\section{APPENDIX D-}

\section{CONTENTS}

1. Derivation of Equations for Analysis of Sodium - Steam Reaction . . 119

2. Analysis of Data for Correlation Between Inlet Orifice Meter Readings (FI-1 and FI-2) and Pressure Drop Between Upstream

Orifice Pressure Taps and Mixing Tank. . . . . : : : . . . . 127

3. Listing of FORTRAN IV Computer Program for Calculation of Results from Steaming of Reactor Vessel .............. 129

4. Listing of Input Data for Calculation of Results from Sodium -

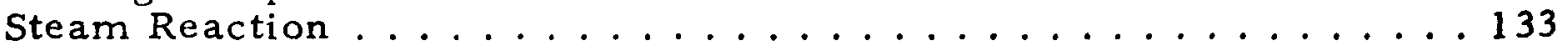


$$
\text { . }
$$ 
$\left(t_{d}\right)=$ time at which data point was taken based on twenty-four hour clock (hr and $\mathrm{min}$ )

NT

$\left(T_{n}\right)=$ nitrogen temperature upstream of inlet orifice $(T I-6)(\bullet F)$

T16

$\left(\Delta P_{n}\right)=$ nitrogen orifice pressure difference $(F I-2)(\%)$

FI2

$\left(T_{B}\right)=$ steam temperature upstream of inlet orifice $(\mathrm{TI}-1)\left({ }^{\circ} \mathrm{F}\right)$

$\mathrm{TI}-1$

$\left(\Delta P_{8}\right)=$ steam orifice pressure difference $(F I-1)(\%)$

FII

$\left(P_{\mathbf{b}}\right)$ = barometric pressure (in. $\left.\mathrm{Hg}\right)$

PB

$\left(P_{m}\right)=$ mixing tank pressure $(P I-2)(p s i g)$

$\left(X_{h}\right)=$ hydrogen fraction in condenser gas effluent $(\%)$

PI2

$\left(P_{a}\right)$ - atmospheric pressure (psia)

$$
\mathrm{P}_{\mathrm{a}}=0.491 \mathrm{P}_{\mathrm{b}}
$$

$\left(P_{t}\right)=$ mixing tank pressure in psia

$$
P_{t}=P_{a}+P_{m}
$$

$\left(M_{s}\right)=$ steam flow rate through inlet orifice $(1 \mathrm{~b}-\mathrm{mole} / \mathrm{min})$

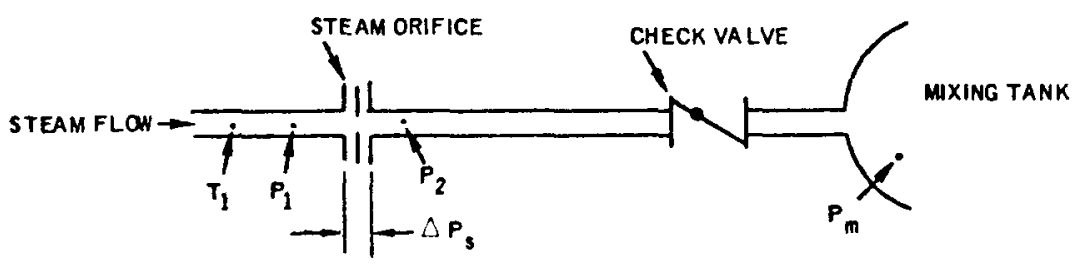

$$
\text { Diagram of Steam Inlet Piping }
$$

From N. C. Ebaugh "Engineering Thermodynamics," Loncaster Press, 1937

p. 115, Equation 13

$$
M=8.02 C_{d} F_{2} \frac{P_{1}}{\sqrt{R I_{1}}} \sqrt{\frac{K}{K-1}} \sqrt{\left(\frac{P_{2}}{P_{1}}\right)^{(K+1) / K}-\left(\frac{P_{2}}{P_{1}}\right)^{2 / K}} \mathrm{lb} / \mathrm{sec}
$$

p. 114, Equation 10

$$
F=\frac{1}{\sqrt{1-\left(\frac{D_{2}}{D_{1}}\right)^{4}\left(\frac{P_{2}}{P_{1}}\right)^{2 / K}}}
$$

where

$$
\begin{aligned}
& C_{d}=\text { orifice discharge coefficient (assumed }=0.61 \text { ) } \\
& A_{2}=\text { orifice area }\left(=1.248 \mathrm{in.}^{2}\right)
\end{aligned}
$$


$P_{2}=$ orifice downstream pressure (psia with $A_{2}$ in sq in.)

$P_{1}=$ orifice upstream pressure (psia with $A_{2}$ in $8 q$ in.)

$K=$ ratio of const. pres. spec, ht. to const, vol. spec. ht. $(=1.29$ for steam under operating conditions)

$R=$ gas constant $\left(=85.4 \mathrm{ft}-1 \mathrm{~b} / 1 \mathrm{~b}-{ }^{\circ} \mathrm{F}\right.$ for steam under operating conditions $)$

$T_{1}=$ orifice upstream temperature $\left({ }^{\circ} \mathrm{F}\right.$ abs $)$

$D_{2}=1 D$ of orifice approach pipe $(=2.067 \mathrm{in.}$ for $2 \mathrm{in.}-\mathrm{Sch} 40$ pipe $)$

$D_{1}=$ orifice diameter $(=1.260$ in. $)$

Equations 3 and 4 may be combined and rearranged to the form

$$
M=8.02 C_{d^{A}} P_{1}\left\{\frac{\left(\frac{K}{K-1}\right)\left(1-r^{(K-1 V K}\right)}{R T_{1}\left[\left(\frac{1}{r}\right)^{2 / K}-\beta^{4}\right]}\right\}^{1 / 2}
$$

where

$$
\begin{aligned}
& \mathbf{r}=\text { orifice pressure ratio }\left(=\mathrm{P}_{2} / \mathrm{P}_{1}\right) \\
& \boldsymbol{\beta}=\text { diameter ratio }\left(=\mathrm{D}_{2} / \mathrm{D}_{1}\right)
\end{aligned}
$$

Direct measurement of $\mathrm{P}_{2}$ was not taken during the operation. Measurement of the gage pressure at $P_{1}$ was taken during part of the operation using PI-13. Analysis is of the data indicated reasonably accurate correlation between the flow-meter reading $(F I-1)$ and the pressure difference $\left[(P I-13)-(P I-2)=P_{1}-P_{t}\right]$ to be given by the equation: (see Appendix D-2)

$$
\left(P_{1}-P_{t}\right)=0.0733(\mathrm{FI}-1)
$$

For the 33 points examined, the average deviation between measured and calculated values was $0.253 \mathrm{psi}$, the standard (root mean square) deviation was 0.336 psi. Considering that the minimum reading for (PI-2) was 9.8 psig and assuming a standard atmosphere of $14.0 \mathrm{psia}$ (at $1440 \mathrm{ft}-6 \mathrm{in}$. elevation) the average deviation in calculating $P_{1}$ would be about $1.02 \%$, the standard deviation about $1.36 \%$.

Using Equation 6, $P_{1}$ is calculated from:

$$
P_{1}=P_{t}+0.0733(F I-1)
$$

The orifice meter (FI-1) measured the pressure difference across the orifice as a fraction of the rated pressure difference $\left(=100\right.$ in. $\left.\mathrm{H}_{2} \mathrm{O}\right)$. The read-out scale on this meter was a square root scale ranging from 0. to $100 \%$ such that $100 \%$ is equivalent to 100 in. $H_{2} \mathrm{O}$. The pressure difference $\left(\Delta \mathrm{P}_{8}\right)$ is therefore

$$
\begin{aligned}
& \Delta P_{B}=[(F I-1) / 100]^{2} \text { in. } H_{2} \mathrm{O} \\
& \therefore r=1-0.000361(F I-1)^{2} / P_{1}
\end{aligned}
$$

where 1 in. $\mathrm{H}_{2} \mathrm{O}=0.0361 \mathrm{psi}$. 
For the orifice flow in $1 b-$ mole $/ \mathrm{min}$

$$
M_{8}=\frac{60}{18}(M) \quad 1 \mathrm{~b}-\mathrm{mole} / \mathrm{min}
$$

where

$$
\begin{aligned}
& 60=\operatorname{seconds} / \mathrm{min} \\
& 18=\text { molecular weight of stearn }
\end{aligned}
$$

Using the calculated results from Equations 7 and 9 and putting numerical values into Equation 5 we have

$$
\begin{aligned}
M_{s} & =\frac{60}{18}(8.02)(0.61)(1.248) P_{1}\left\{\frac{\left(\frac{1.29}{1.29-1}\right)\left(1-r^{(1.29-1) / 1.29}\right)}{\left.85.4 T_{1} l\left(\frac{1}{r}\right)^{2 / 1.29}-\left(\frac{1.260}{2.067}\right)^{4}\right]}\right\}^{1 / 2} \\
& =20.35 P_{1}\left\{\frac{4.45\left(1-r^{0.225}\right)}{\left.85.4 \mathrm{~T}_{1}\left(\frac{1}{\mathrm{r}}\right)^{1.55}-0.138\right)}\right\}^{1 / 2} \mathrm{lb/ \textrm {mole } / \mathrm { min }},
\end{aligned}
$$

where $T_{1}=460+\left(T_{s}\right)$

$$
M_{s}=4.64 P_{1}\left\{\frac{\left(1-r^{0.255}\right)}{\left(460+T_{s}\right)\left(\left(\frac{1}{r}\right)^{1.55}-0.138\right]}\right\}^{1 / 2} \quad \text { lb-mole/min }
$$

$\left(M_{n}\right)$ Nitrogen flow rate through inlet orifice in $1 b-$ mole $/ \mathrm{min}$

The nitrogen flow rate is calculated in the same manner as the steam flow rate, using Equation 5 and the following constants:

$$
\begin{array}{rlrl}
C_{\mathbf{d}} & =0.61 \text { (as sumed) } & & D_{2}=1.114 \mathrm{in} . \\
A_{2}=0.974 \mathrm{in} .{ }^{2} & D_{1}=2.067 \mathrm{in} . \\
K & =1.40 & & \text { Molecular wt }=28 \\
R=55.2 \mathrm{ft}-1 \mathrm{~b} / 1 \mathrm{~b}-{ }^{\circ} \mathrm{F} & &
\end{array}
$$

The upstream pressure $\left(P_{1}\right)$ for the nitrogen orifice is based on analysis of the data taken on pressure gage (PI-14) which was also used during part of the operation. Analysis of the data indicated correlation between the flowmeter reading (FI-2) and the pressure difference $\left[(P I-14)-(P I-2)=P_{1}-P_{t}\right]$ to be given by the equation:

$$
\left(P_{1}-P_{t}\right)=0.0465(F I-2) \text { psia (see Appendix D-2) }
$$

For the 36 points examined, the average deviation between measured and calculated values was $0.164 \mathrm{psi}$, the standard (root mean square) deviation was $0.217 \mathrm{psi}$. 
Considering that the minimum value for $\left(P_{1}-P_{t}\right)$ was 3.4 psig and as suming a standard atmosphere of $14.0 \mathrm{psia}$ (at $1440 \mathrm{ft}-6 \mathrm{in}$. elevation) the average deviation in calculating $P_{1}$ would be about $0.94 \%$, the standard deviation about $1.19 \%$.

Using Equation 6, $P_{1}$ is calculated from:

$$
P_{1}=P_{t}+0.0465(F I-2)
$$

The nitrogen orifice meter (FI-2) was similar to the steam orifice meter (FI-1), having a 0 to $100 \%$ square root scale with $100 \%$ equivalent to 100 in. $\mathrm{H}_{2} \mathrm{O}$. The pressure drop $\left(\Delta P_{n}\right)$ is therefore

$$
\begin{aligned}
& \Delta P_{n}=[(F I-2) / 100]^{2} \text { in. } H_{2} \mathrm{O} \\
& \therefore x=1-0.000361(F I-2)^{2} / P_{1}
\end{aligned}
$$

(NOTE: The symbols $P_{1}, r$, and $T_{1}$ are used for both nitrogen and steam calculations since these are not stored simultaneously in the computer.)

Using the calculated results from Equations 14 and 16 and putting numerical values into Equation 5 we have

$$
\begin{aligned}
& M_{n}=\frac{60}{28}(8.02)(0.61)(0.974) P_{1}\left\{\frac{\left(\frac{1.40}{1.40-1}\right)\left(1-r^{(1.40-1) / 1.40}\right)}{55.2 \mathrm{~T}_{1}\left[\left(\frac{1}{r}\right)^{2 / 1.40}-0.085\right]}\right\}^{1 / 2} \\
& M_{n}=10.2 P_{1}\left\{\frac{3.5\left(1-r^{0.286}\right)}{\left.55.2 \mathrm{~T}_{1} \mid\left(\frac{1}{r}\right)^{1.428}-0.085\right]}\right\}^{1 / 2} \mathrm{lb- \textrm {mole } / \mathrm { min }}
\end{aligned}
$$

where $T_{1}=460+T_{n}$

$$
M_{n}=2.57 P_{1}\left\{\frac{\left(1-r^{0.286}\right)}{\left(460+T_{n}\right)\left[\left(\frac{1}{r}\right)^{1.428}-0.085\right]}\right\}^{1 / 2} 1 \mathrm{~b}-\mathrm{mole} / \mathrm{min}
$$

$\left(w_{s}\right)$ Steam flow rate through inlet orifice in $1 b / h r$

$$
\begin{aligned}
& \mathrm{w}_{\mathrm{B}}=18(60) \mathrm{M}_{\mathrm{B}} \\
& \mathrm{W}_{\mathrm{B}}=1080 \mathrm{M}_{\mathrm{s}}
\end{aligned}
$$


$\left(Q_{n}\right)$ Nitrogen flow through inlet orifice in $8 \mathrm{cfm}$

$$
Q_{n}=\frac{R^{\prime} T_{s t d}}{P_{\text {std }}} M_{n} \text { scfm }
$$

where

$$
\begin{gathered}
R^{\prime}=\text { universal gas const. }\left(=1545 \mathrm{ft}-\mathrm{lb} / \mathrm{lb}-\text { mole }-{ }^{\circ} \mathrm{F}\right) \\
T_{\text {std }}=\text { standard temperature }\left(=520^{\circ} \mathrm{F} \text { abs }\right) \\
P_{\text {std }}=\text { standard pressure }(=2116.8 \mathrm{psf}) \\
Q_{\mathrm{n}}=379 \mathrm{M}_{\mathrm{n}}
\end{gathered}
$$

$\left(t_{m}\right)$ Data time in minutes of 1440 minute day

The data time was recorded in hours (a) and minutes (b) based on a 24 -hour clock. The form of the record is

$$
(100 a) \text { hours }+(b) \text { minutes }
$$

Therefore, in terms of a 1440 minute clock, the time is:

$$
t_{m}=60 \frac{(100 a)}{100}+b
$$

In the computer, this was performed by integer calculations which truncate the remainder on division

$$
t_{m}=\left[\frac{(100 a+b)}{100}\right] 60+(100 a+b)-\left|\frac{(100 a+b)}{100}\right| \text { minutes }
$$

where $\left[\frac{(100 a+b)}{100}\right\}=a$

$(\Delta t)$ Time interval between data points in minutes

The time interval is calculated from the difference of the recorded times of successive data points

$$
\Delta t=t_{m(i+1)}-t_{m(i)} \text { minutes }
$$

where subscript (i) is the number of the data point

$\left(S_{s(i)}\right)$ Steam flow over time interval in lb-moles

It is as sumed that the average steam flow over the time interval is equal to the average of the flow rates at the beginning and end of the interval (data points) multiplied by the time interval

$$
S_{s(i)}=\frac{M_{s(i)}+M_{s(i+1)}}{2}(\Delta t)
$$


$\left(C_{s(j)}\right)$ Total steam flow since start of operation in $1 \mathrm{~b}$-mole

$$
c_{s(j)}=\sum_{i=1}^{i=j} s_{s(i)}
$$

where limit $j=$ number of data point at end of last time interval considered.

$\left(F_{s}\right)$ Volume fraction of steam in gas entering reactor in $\%$

Based on Mole $\%=$ Volume $\%$

$$
F_{s}=\frac{M_{s}}{M_{s}+M_{n}} 100
$$

$\left(M_{0}\right)$ Sodium reaction rate (with steam) in $1 \mathrm{~b}-\mathrm{mole} / \mathrm{min}$

Assuming steady state conditions (i.e., nitrogen inlet flow = nitrogen outlet flow) and the condenser effluent gas is all nitrogen and hydrogen. The $\mathrm{lb}-\mathrm{mole} / \mathrm{min}$ of hydrogen leaving the condenser $\left(M_{h}\right)$ is:

$$
M_{h}=\frac{\left(X_{h} / 100\right)}{1-\left(X_{h} / 100\right)} M_{n} \quad \text { lb-mole } / \text { min }
$$

The chemical equation for the steam-sodium reaction indicates that one mole of hydrogen is formed when two moles of sodium react with steam

$$
\begin{aligned}
& 2 \mathrm{H}_{2} \mathrm{O}+2 \mathrm{Na} \rightarrow 2 \mathrm{NaOH}+\underset{\mathrm{H}_{2}}{\rightarrow}+2 \text { Sodium Hydroxide }+1 \text { Hydrogen } \\
& 2 \text { Steam }+2 \text { Sodium }=2 \text { Sodium }
\end{aligned}
$$

Therefore for each mole of hydrogen in the effluent gas, two moles of sodium were reacted in the system

$$
\begin{aligned}
& M_{0}=2 M_{h} \\
& M_{0}=\frac{\left(X_{h} / 50\right)}{1-\left(X_{h} / 100\right)} M_{n} \quad \text { lb-mole } / \text { min }
\end{aligned}
$$

$\left(\mathrm{W}_{\mathrm{o}}\right)$ Sodium reaction rate in $\mathrm{lb} / \mathrm{hr}$

$$
\begin{aligned}
& \mathrm{w}_{0}=23(60) \mathrm{M}_{0} \\
& \mathrm{w}_{0}=1380 \mathrm{M}_{0} \mathrm{lb} / \mathrm{hr}
\end{aligned}
$$

$\left(S_{o(i)}\right)$ Sodium reacted in time interval in $1 \mathrm{~b}-$ mole

$$
S_{o(i)}=\frac{M_{o(i)}+M_{o(i+1)}}{2} \Delta t \quad \text { lb-mole }
$$


$\left(C_{o(j)}\right)$ Total amount of sodium reacted since start of operation in lb-mole

$$
c_{o(j)}=\sum_{i=1}^{i=j} s_{o(i)} \quad l b-\text { mole }
$$

$\left(e_{(i)}\right)$ Process efficiency during time interval in percent

For $100 \%$ efficiency each $1 \mathrm{~b}$-mole of steam entering the reactor would combine with one $\mathrm{lb}$-mole of sodium. The process efficiency over the interval is defined as the ratio of rate of sodium reacted (in $1 \mathrm{~b}-\mathrm{mole} / \mathrm{min}$ ) to rate of steam entering the reactor vessel (in lb-mole/min)

$$
e_{(i)}=\frac{M_{0}}{M_{s}} 100 \quad \text { percent }
$$

EFI

$\left(\eta_{(j)}\right)$ Average process efficiency since start of operation in percent

$$
\eta_{(j)}=\frac{c_{o(j)}}{C_{s(j)}} 100 \text { percent }
$$

EFA

$\left(D_{8(j)}\right)$ Total steam flow since start of operation in $1 b$

$$
D_{s(j)}=18 C_{s(j)}
$$

$\operatorname{csT}$

$\left(D_{o(j)}\right)$ Total amount of sodium reacted since start of operation in lb

$$
D_{o(j)}=23 C_{o(j)}
$$

CNA 
$$
\text { . }
$$ 
ANALYSIS OF DATA FOR CORRELATION BETWEEN INLET ORIFICE METER READINGS (FI-1 AND FI-2) AND PRESSURE DROP BETWEEN UPSTREAM ORIFICE PRESSURE TAPS AND MIXING TANK

\section{STEAM INLET}

(M) Number of points examined

$$
N=33
$$

$\left(\sum \Delta P_{1}\right)$ Sum of measured pressure drops (psi)

$$
\sum \Delta P_{1}=[(P I-13)-(P I-2)]=84.1
$$

$\left(\sum F I-1\right)$ Sum of orifice meter readings $(\%)$

$$
\sum(F I-1)=1147.4
$$

The assumed form of the correlating equation is:

$$
\Delta P=m(F I-1)
$$

(m) Average proportionality constant

$$
\begin{aligned}
& \mathrm{m}=\sum \Delta \mathrm{P}_{1} / \sum(F I-1)=84.1 / 1147.4 \\
& \mathrm{~m}=0.0733
\end{aligned}
$$

$\left(\sum e_{1}\right)$ Sum of absolute differences between measured pressure drops and calculated pressure drops

$$
\sum e_{1}=\sum\left|\Delta P_{1}-m(F I-1)\right|=8.34
$$

$\left(\bar{e}_{1}\right)$ Average deviation

$$
\overline{\mathbf{e}}_{\mathbf{i}}=\left(\sum \mathrm{e}_{1}\right) / \mathrm{M}=8.34 / 33=0.253
$$

$\left(\sum_{1}^{2}\right)$ Sum of squares of difference between calculated and measured values

$$
\sum \mathrm{e}_{1}^{2}=\sum\left[\Delta \mathrm{P}_{1}-\mathrm{m}(\mathrm{FI}-1)\right]=3.720
$$

$\left(\sigma_{1}\right)$ Standard deviation

$$
\begin{aligned}
& \sigma_{1}=\mid\left(\sum \mathrm{e}_{1}^{2} /\left.\mathrm{M}\right|^{1 / 2}=3.720 / 33^{1 / 2}\right. \\
& \sigma_{1}=0.336
\end{aligned}
$$


NITROGEN INLET

(N) Number of points examined

$$
N=36
$$

$(\Sigma \Delta P)$ Sum of measured pressure drops

$$
\sum \Delta P_{2}=\sum[(P I-14)-(P I-2)]=70.5
$$

( $\left.\sum F I-1\right)$ Sum of orifice meter readings

$$
\sum(F I-2)=1518.9
$$

The assumed form of the correlating equation is:

$$
\Delta P_{2}=n(F I-2)
$$

(n) Average proportionality constant

$$
\begin{aligned}
& \mathbf{n}=\sum \Delta \mathrm{P}_{2} / \sum(F I-2)=70.5 / 1518.9 \\
& \mathbf{n}=0.0465
\end{aligned}
$$

$\left(\sum e_{2}\right)$ Sum of absolute differences between measured pressure drops and calculated pressure drops

$$
\sum e_{2}=\sum\left|\Delta P_{2}-n(F I-2)\right|=5.91
$$

$\left(\bar{e}_{2}\right)$ Average deviation

$$
\overline{\mathbf{e}}_{2}=\left(\sum \mathrm{e}_{2}\right) / \mathrm{N}=5.91 / 36=0.164 \mathrm{psi}
$$

$\left(\sum e_{2}^{2}\right)$ Sum of squares of difference between calculated and measured values

$$
\sum e_{2}^{2}=\sum\left[\Delta P_{2}-n(F I-2)\right]=1.698
$$

$\left(\sigma_{2}\right)$ Standard deviation

$$
\begin{aligned}
& \sigma_{2}=\left|\left(\mathrm{e}_{2}^{2}\right) / \mathrm{N}\right|^{1 / 2}=1.698 / 36 \\
& \sigma_{2}=0.217 \mathrm{psi}
\end{aligned}
$$

RECOMMENDED EQUATIONS FOR ESTIMATING PRESSURE DIFFERENCE BETWEEN ORIFICE UPSTREAM PRESSURE TAPS AND MIXING TANK

Steam:

$$
\Delta P_{1}=0.0733(\mathrm{FI}-1) \mathrm{psi}
$$

Nitrogen:

$$
\Delta P_{2}=0.0465(F I-2) p s i
$$


ISN 0002

ISN 0003

ISN $\mathrm{COO4}$

ISN 0005

ISN COO6

ISN 0007

ISN 0008

ISN $C 009$

ISN 0010

ISN 0011

ISN 0012

ISN 0013

ISN 0014

ISN C016

ISN $\quad 017$

ISN 0018

ISN 0019

ISN 0020

ISN COZI

ISN 0022

ISN $\mathrm{CO} 23$

C
HNPF RETIREMENT

CALCULATION OF RESULTS FROM STEAMING OF REACTOR VESSEL

00000100

00000200

00000300

00000400

00000450

IMPLICIT REAL $* g(A-H, C-Z)$

$M$ TE $=0$

$Y S T=0,0$

$C U M S Y=C . O$

00000500

00000600

00000700

00000800

UIMN2 $=0.0$

YNA $=0.0$

C UMNA $=$ C. 0

$M S=735$

$N=C$

$M=C$

IC $N=N+1$

IFIN.GT.2OI GO TO 75

WRI TE $(6,11)$

11 FORMATI $1 \% \cdots, 4 X, \cdot H \Lambda P F$ RETIREMENT $\%,, 4 X, \cdot$ RESULTS FROM STEAMING

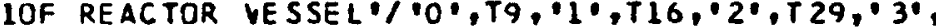

$2^{\prime}, T 48,5^{\circ}, T 58,6^{\prime}, T 67, T^{\prime}, T 77,8^{\prime}, T 87,9^{\prime}, T^{\prime} 98, \cdot 10^{\prime} /$

00001100

00001200

00001210

00001220

00001225

00001226

00001230

00001234

00001236

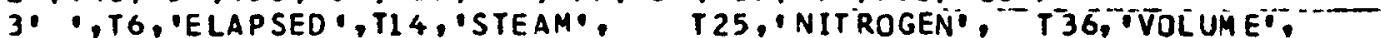

$0000 \lcm{238}$

$4 T 4$, ' TOTAL.

T55, 'VOLUME " T63, SSODIJMP, T74, PROCESS: 00001240

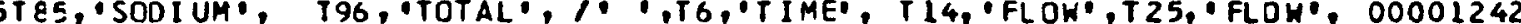

6T36. 'PERCEN1', T44.'STEAM', T55, PERCENT', T63, 'REACTION', 00001244

T85, PREACTED '

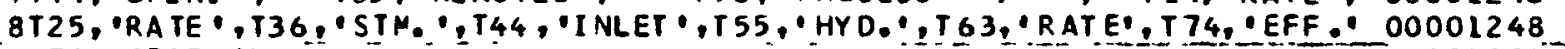

9, TS6, 'EFF.'1 WRI TE $(6,12)$

00001250

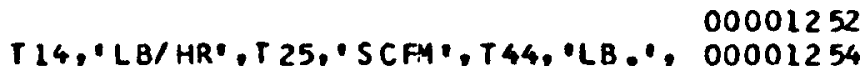

12 FORMATI $0 \cdot, T 6$, 'HR/MIA'.

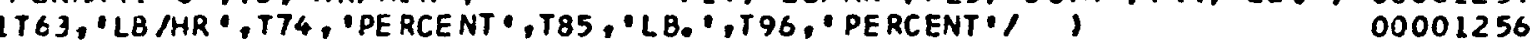

READ INPUT DATA

00001400

00001500

20 FORMATE 15.707 .11

00001700

\section{START CALCULATIOAS}

00001900

00001900
00002000

00002100

$M=M+1$

A TMOSPHERIC PRESSURE PSIA

00002200

MIXING TANK PRESSURE PSIA 


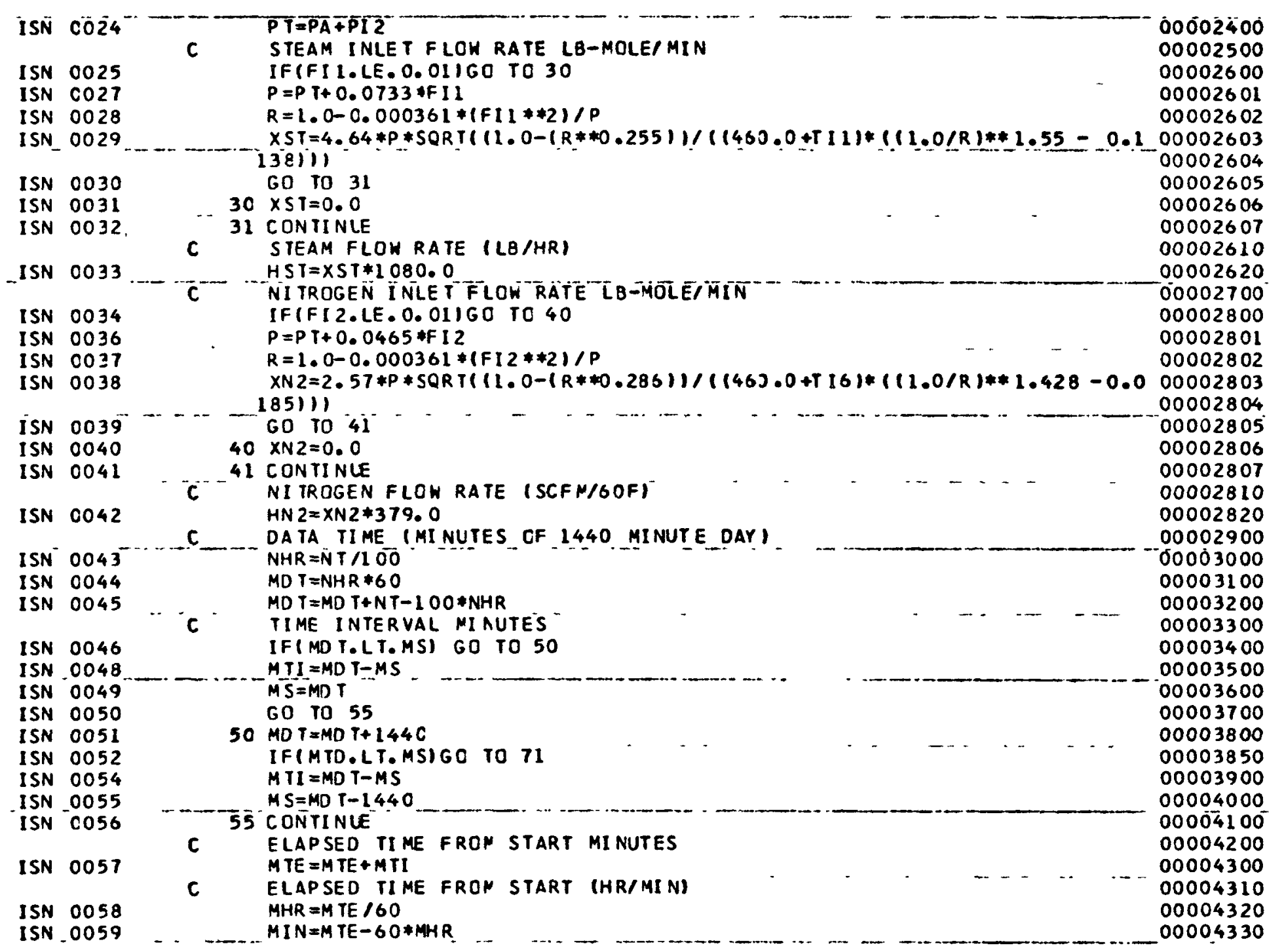




\begin{tabular}{|c|c|}
\hline $\begin{array}{l}\text { ISN } \\
\text { ISN } \\
\text { ISN }\end{array}$ & $\begin{array}{l}0060 \\
0061 \\
0062\end{array}$ \\
\hline$I S N$ & 0063 \\
\hline $\begin{array}{l}\text { ISN } \\
\text { ISN }\end{array}$ & $\begin{array}{l}0064 \\
0065\end{array}$ \\
\hline ISN & 0066 \\
\hline ISN & 0067 \\
\hline ISN & 0068 \\
\hline ISN & 0069 \\
\hline $\begin{array}{l}\text { ISN } \\
\text { ISN }\end{array}$ & $\begin{array}{l}0070 \\
\text { c071 }\end{array}$ \\
\hline ISN & 0072 \\
\hline $\begin{array}{l}\text { ISN } \\
\text { ISN } \\
\text { ISN } \\
\text { ISN } \\
\text { ISN }\end{array}$ & $\begin{array}{l}0073 \\
0075 \\
0076 \\
0077 \\
0078\end{array}$ \\
\hline $\begin{array}{l}\text { ISN } \\
\text { ISN } \\
\text { ISN } \\
\text { ISN } \\
\text { ISN }\end{array}$ & $\begin{array}{l}C 079 \\
C 081 \\
0082 \\
0083 \\
0084\end{array}$ \\
\hline ISN & COQS \\
\hline ISN & Co\&6 \\
\hline ISN & 0087 \\
\hline & 3088 \\
\hline
\end{tabular}

STEAM MASS FLOW OYER TIME INTERVAL LB-YOLE $X M T I=M T I$ $S T I=(Y S T+X S I) * X M T I / 2.0$

$Y \leq T=X S T$

C ACCUM. STM. FLCW FRCM START LB-MOLE

CLMST $=$ CUMST+ STI

c

NI TROGEN MASS FLCH

$X N I=(Y N 2+X N 2) * X M I I / 2.0$

$Y N 2=X N 2$

C

ACCLM. N2 FLOW CVER TIME INTERVAL LB-MOLE

......... - - 00004400

CUMN2 = UMN2+XNI

INLET STEAM FRACTION PERCENT

$F S T=X S T * 100.0 /(X S T+X N 2)$

C SODIUM REACTION RATE LB-MOLE/MIN

$X N A=R H 2 * X N 2 /(11.0-R H 2 / 100,1 * 50.01$

SODI UM REACTI ON RATE (LB/HR)

HNA $=X N A * 1380.0$

C SODIUM REACTED IN TIME INTERVAL LB-MOLE

$X N A I=($ YNA+ XNA $) * X N T I / 2.0$

$Y N A=X N A$

C ACCUM. NA REACTED IA TIME INTERVAL LQ-mOLE

ACCUM. NA REACTED
C LMNA $=$ C UMNA + XNAI

C PROCESS EFFICIENCY DURING TIME INTERVAL PERCENT

$I F I F I 1$. LE. 0.0001, GO TO 60

00004500

00004600

00004800

$E F I=1$ CC. $0 *$ XNA $/ X S T$

60 TO 65

6C EFI $=0.0000$

65 CONIINLE

ACCUM. PROCESS EFFICIENCY PERCENT

IFIMTI . LE. 1 ) GC TO 66

EFA $=100$. O*CLMNA /CUMST

00004900

00005100

00005200

00005300

00005400

00005500

.60 TO 68

$66 E F A=0.000$

68 CONTINLE

c

ACCUM. STM. FLOW IN (LB)

C ST $=$ C UMST $\$ 1$ 18:0

C ACCUM. N2 FLOW IA (LB)

CN $2=C$ UMN $2 * 28.0$

C ACCUM. NA REACTEO (LB)

$C N A=C$ UMNA $\$ 23.0$

00005600

00005700

00005800

00005810

00005820

00005900

$-00006000$

00006100

00006200

00006300

00006400

00006410

00006410
00006500

00006510

00006520

00006530

00006600

00006610

00006610

00006710

00006720

00006730

00006800

00006900

00007000

00007100

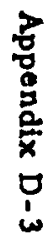

$c$

00007200

00007300

00007400 00007500 
ISN 0089

ISN 0090

ISN 0092

ISN $\operatorname{COS} 3$

ISN 0094

ISN 0095

ISN COSO

ISN COST

ISN $\operatorname{Cog} 8$

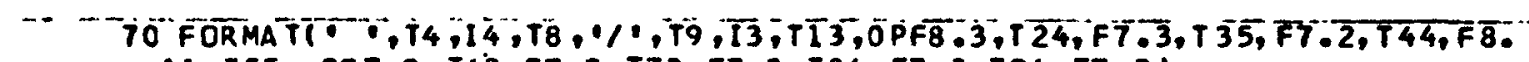
$11, \mathrm{~T} 55$, PF $7,3, T 63, F 7 \cdot 3, T 73, F 7,3, T 84, F 7,3, T 96, F 7,31$

IF (M.LT. 32)GO TO 15

C LINE COUNTER RESET

GO TO 5

WRI TE 16,72

72 FORMATI

75 CONTINLE

CALL EXIT

STOP

END
$000 \overline{7600}$ 00007700

00007800

00007900

00008000

00008010

00008020

00008100

00008150

00008175

00008200

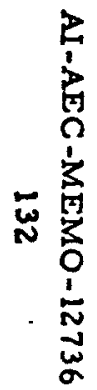




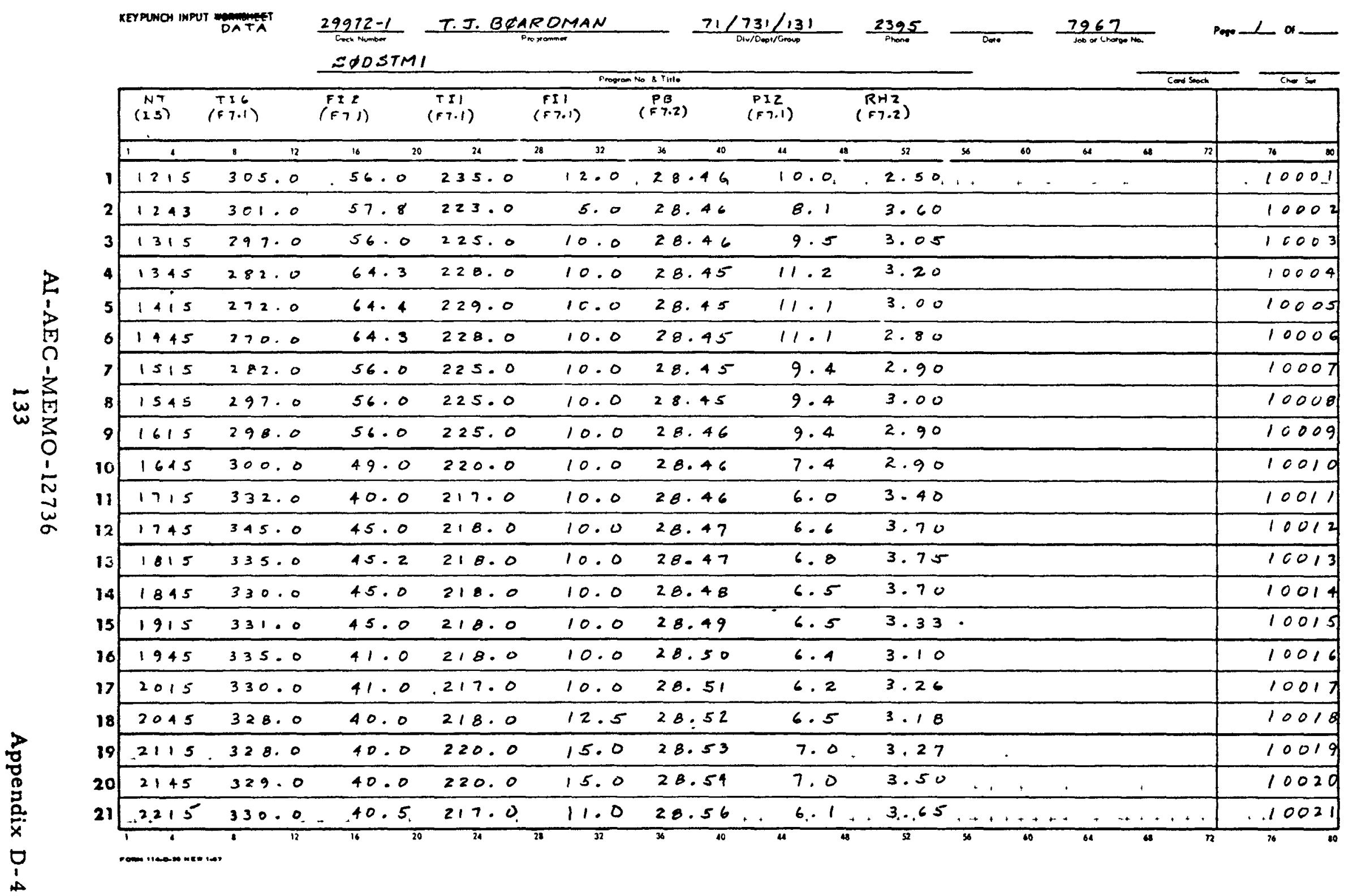




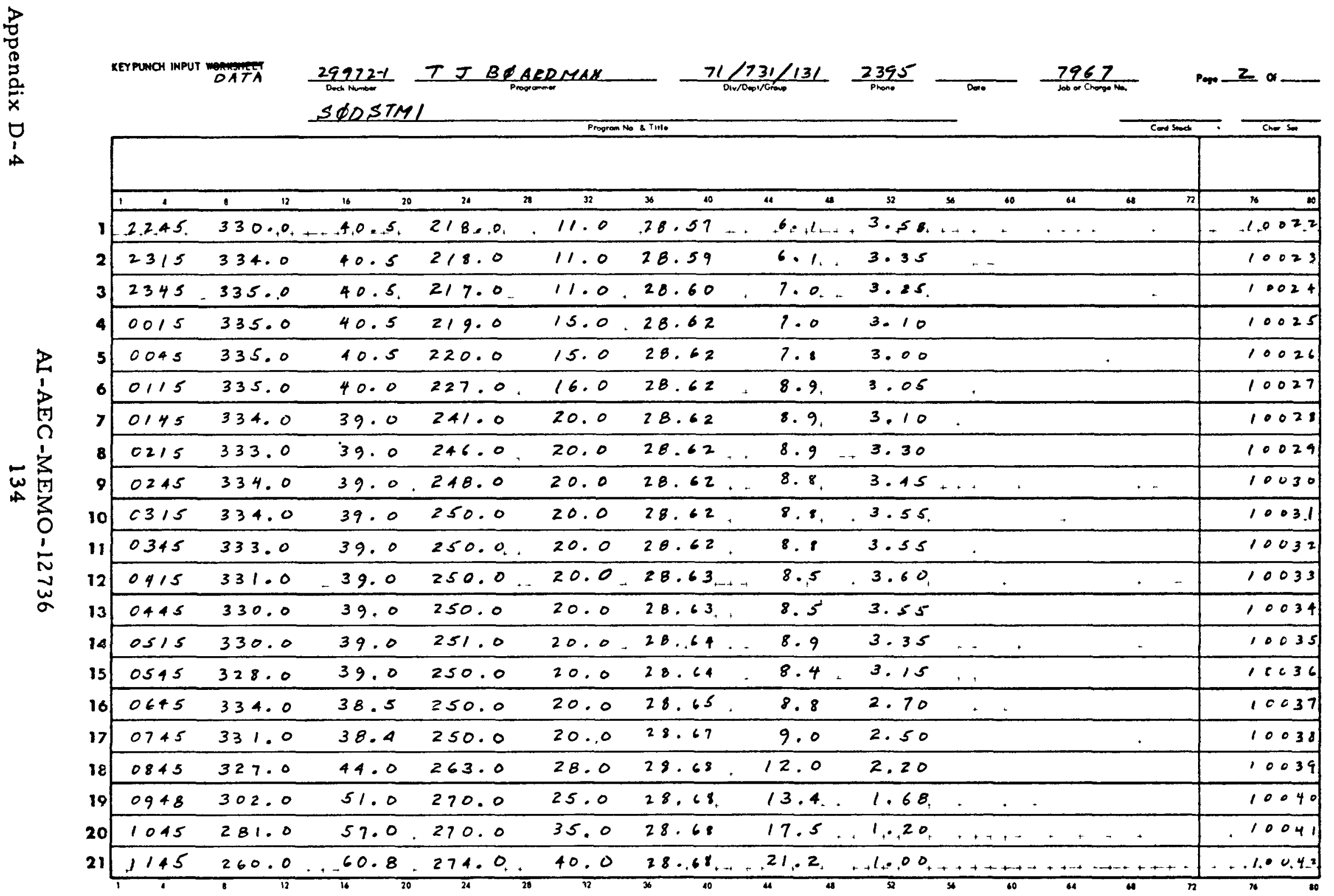


KEYPUNCH INPUT DAFA

$29972-1 T J$ BLAROMAN

$31 / 731 / 131$

$\frac{2355}{\text { Pisong }}$

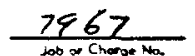

Poge 3 o

SEDSTMI

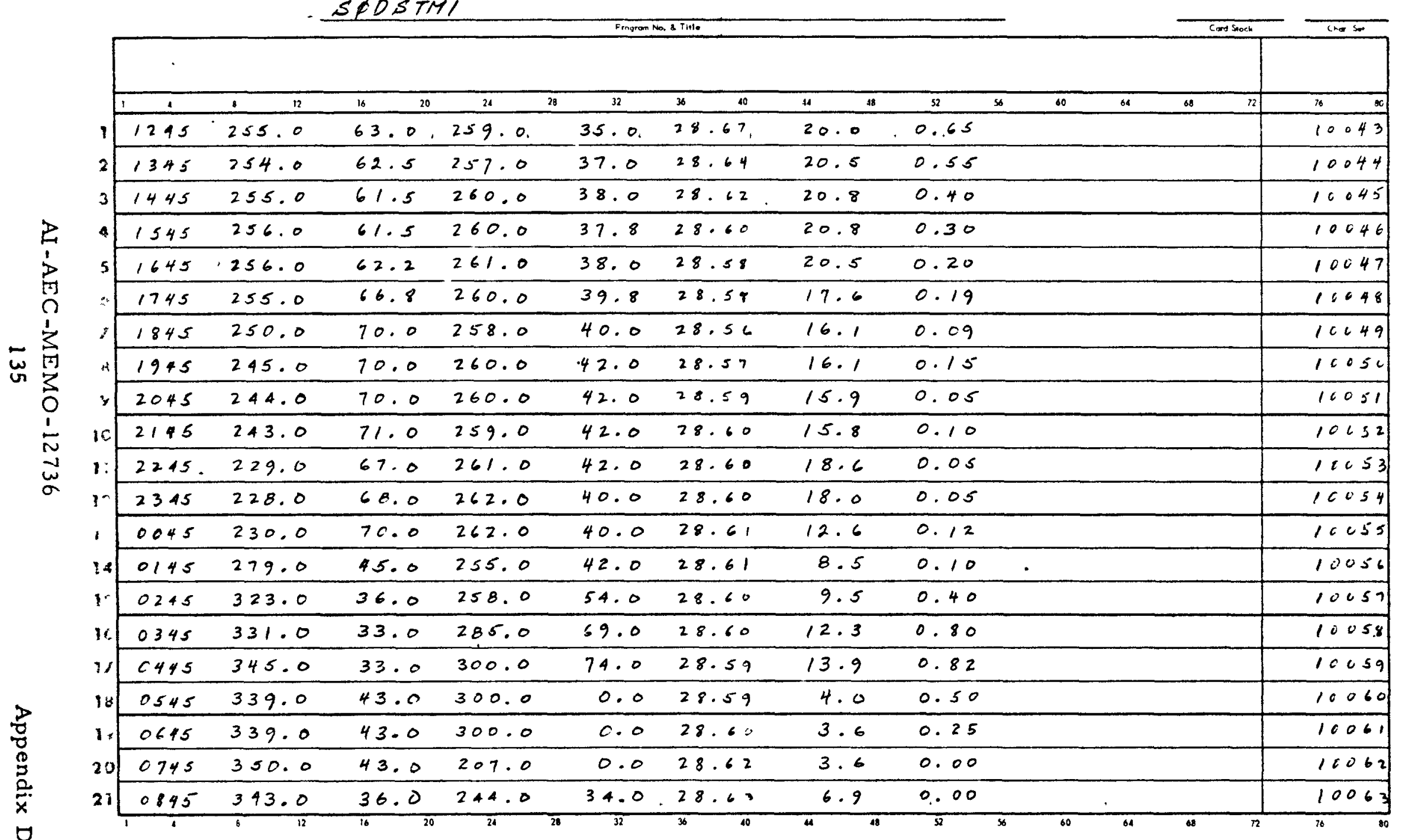




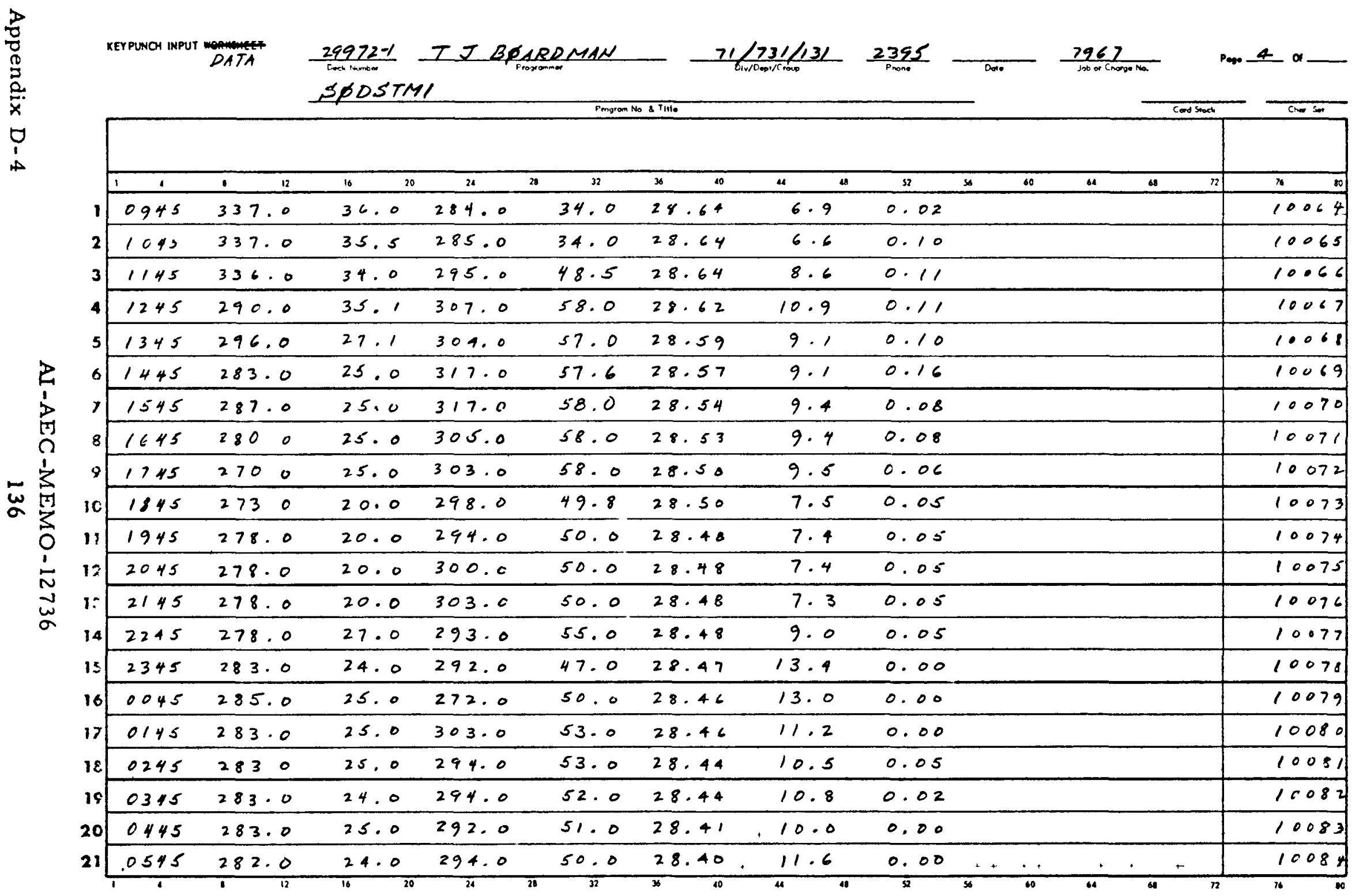




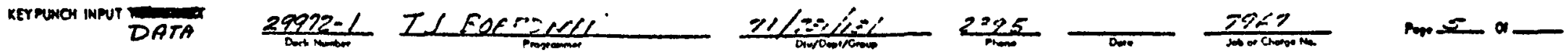

sisester

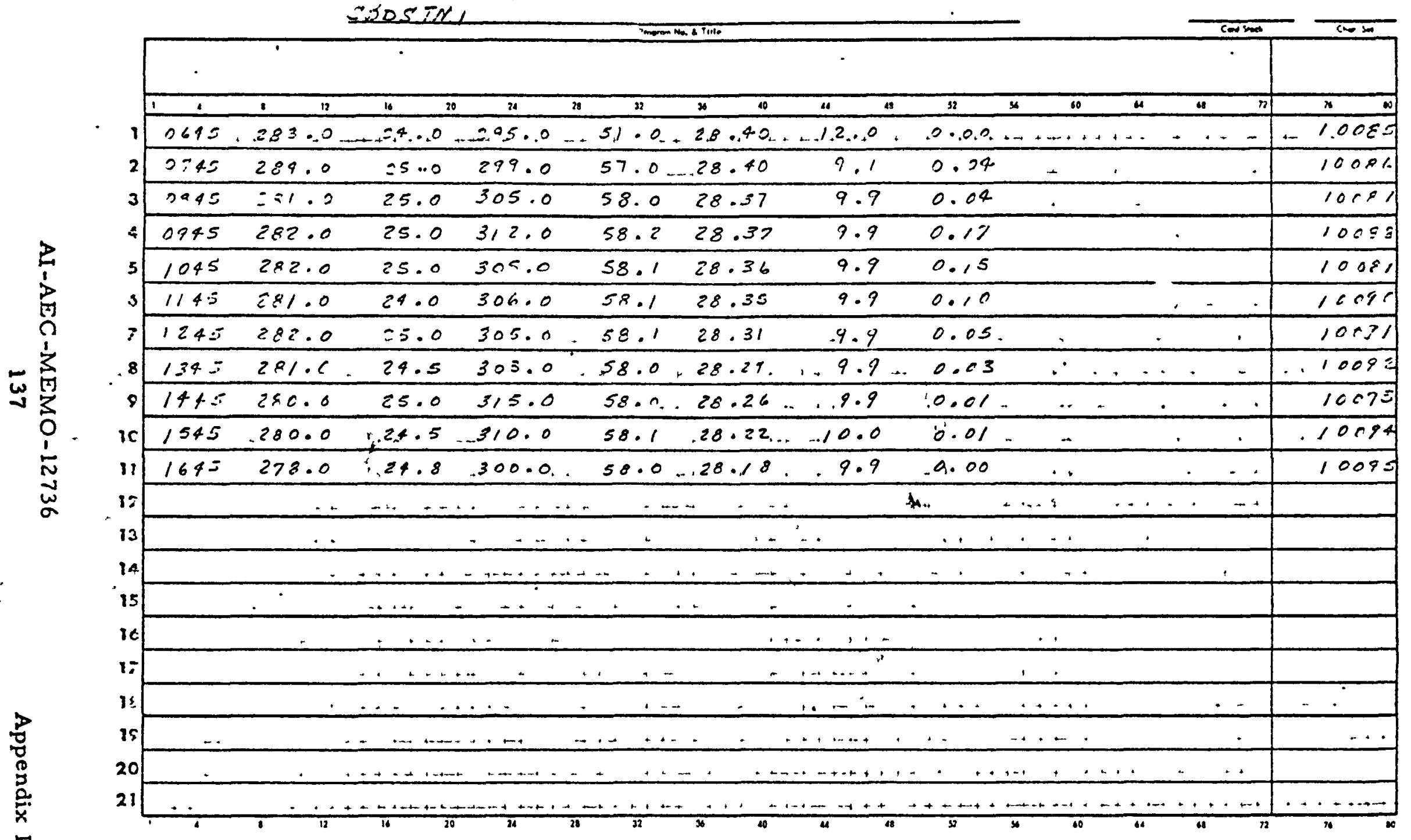

